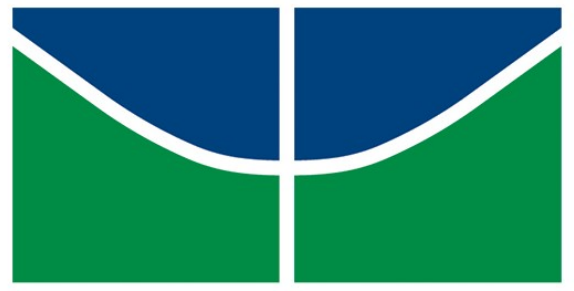

Universidade de Brasília

Instituto de Ciências Sociais

Departamento de Antropologia

Programa de Pós-Graduação em Antropologia Social

Gustavo Belisário D'Araújo Couto

\title{
BRINCANDO NA TERRA: TEMPO, POLÍTICA E FAZ DE CONTA NO ACAMPAMENTO CANÃ̃ (MST - DF)
}




\section{BRINCANDO NA TERRA: TEMPO, POLÍTICA E FAZ DE CONTA NO ACAMPAMENTO CANÃ̃ (MST - DF)}

Dissertação de mestrado apresentada ao Programa de Pós-Graduação em Antropologia Social da Universidade de Brasília, como parte dos requisitos para a obtenção do título de Mestra em Antropologia Social.

Orientadora: Antonádia Monteiro Borges

Banca Examinadora:

Prof. ${ }^{\text {a }}$ Dr. ${ }^{\text {a }}$ Antonádia Monteiro Borges (DAN/UnB - Presidenta)

Prof. ${ }^{a}$ Dr. ${ }^{a}$ Flávia Ferreira Pires (DCS/UFPB - Avaliadora)

Prof. ${ }^{\text {a }}$ Dr. ${ }^{\text {a Luciana Hartmann (CEN/UnB - Avaliadora) }}$

Prof. Dr. Guilherme José da Silva Sá (DAN/UnB - Suplente)

Brasília

2016 
ao amigo marcelo caetano 


\section{agradecimentos}

agradeço à minha família. à minha mãe kátia, ao meu pai rogério, à minha irmã carolina e ao meu irmão thiago.

agradeço ao caê por me tranquilizar nas noites em que nada parecia dar certo. ao dé e ao joão por aguentarem o mau humor e o estresse mais de perto. à mel e à lu félix pela sensibilidade e doçura. à natalia maria, jack e dyarley por suas intensidades inspiradoras. ao argus pela leitura deleuziana atenta. ao vitor pelas piadas. à nat por ter devolvido o meu filme. aos demais amigos cuia, botelho, xokito, pri, ju, ian, luisa, coxinha, dimi, duds dantas, digo, lari, paulo, gui, sebba.

às famílias que lutam no canaã. à maria rosa por ter me recebido em sua casa tão afetuosamente. ao flavão pela confiança. às crianças que lutam no mst e ocupam a terra com sorrisos e brincadeiras. ao eiv por ter me levado ao canaã. às militantes que constroem diariamente o mst lutando, plantando, ocupando e vivendo.

agradeço às companheiras e aos companheiros da insurgência, organização política que se soma a gerações de lutadoras e lutadores do passado e do futuro na construção de um socialismo com liberdade. agradeço principalmente à militância do df mais próxima de mim - chico, talita, licio, ingrid, aline, helena, maria, keka, lourival, mário, rafa, max, vini e evelyn - e às babadeiras da corrente - cesinha, nadja, mari, lipe, rô, luka, remom, maria. à piauiense déb que não é nem do df e nem babadeira, mas é amiga né?

agradeço às amigas, aos amigos e colegas do programa pelos aprendizados e trocas de ideias, tão essenciais durante a minha formação no mestrado. à stella pela amizade que construímos nesses dois anos e pela sugestão do título da dissertação. à marcela pela ternura e pelas leituras dos capítulos que se desenhavam. à zeza e ranna por segurar as pontas e compartilhar as angústias, principalmente na reta final. ao gui moura pelas conversas na sala da katacumba. à mariana lima por me sugerir fazer o eiv e por compartilhar de questões sobre a infância e às crianças que lutam. aos demais colegas que entraram no ppgas comigo: vinicius, matheus, pézão, bianca, nicolas, carol, felipe e fabiana. agradeço muitíssimo ao gesta e às gestantes pela possibilidade experimentação de ideias, leitura generosa e debate excepcional. roberto, isabele, denise, fabíola, cláudia, nathan, stéfane, luiza, eliane e matheus. 
à antonádia borges por me acompanhar em minha trajetória desde o final da graduação. obrigado por me ensinar que o pensamento pode transcender barreiras, limites e certezas e que há muitas pesquisas instigantes sendo feitas fora da academia. agradeço por, mesmo passando por um momento difícil, ter me orientado a ler literatura e poesia quando a criatividade faltasse.

aos funcionários da pós e da graduação, jorge, rosa, thaís, idamar e branca pela dedicação e colaboração. às professoras cristina patriota, soraya fleischer, marcela coelho e ao professor guilherme sá pelas disciplinas que valeram a pena serem feitas.

às professoras flávia pires e luciana hartmann por se disporem a estar na banca e a dialogarem comigo e com este trabalho. 
"O homem chega à sua maturidade quando encara a vida com a mesma seriedade que uma criança encara uma brincadeira." Friedrich Nietzsche

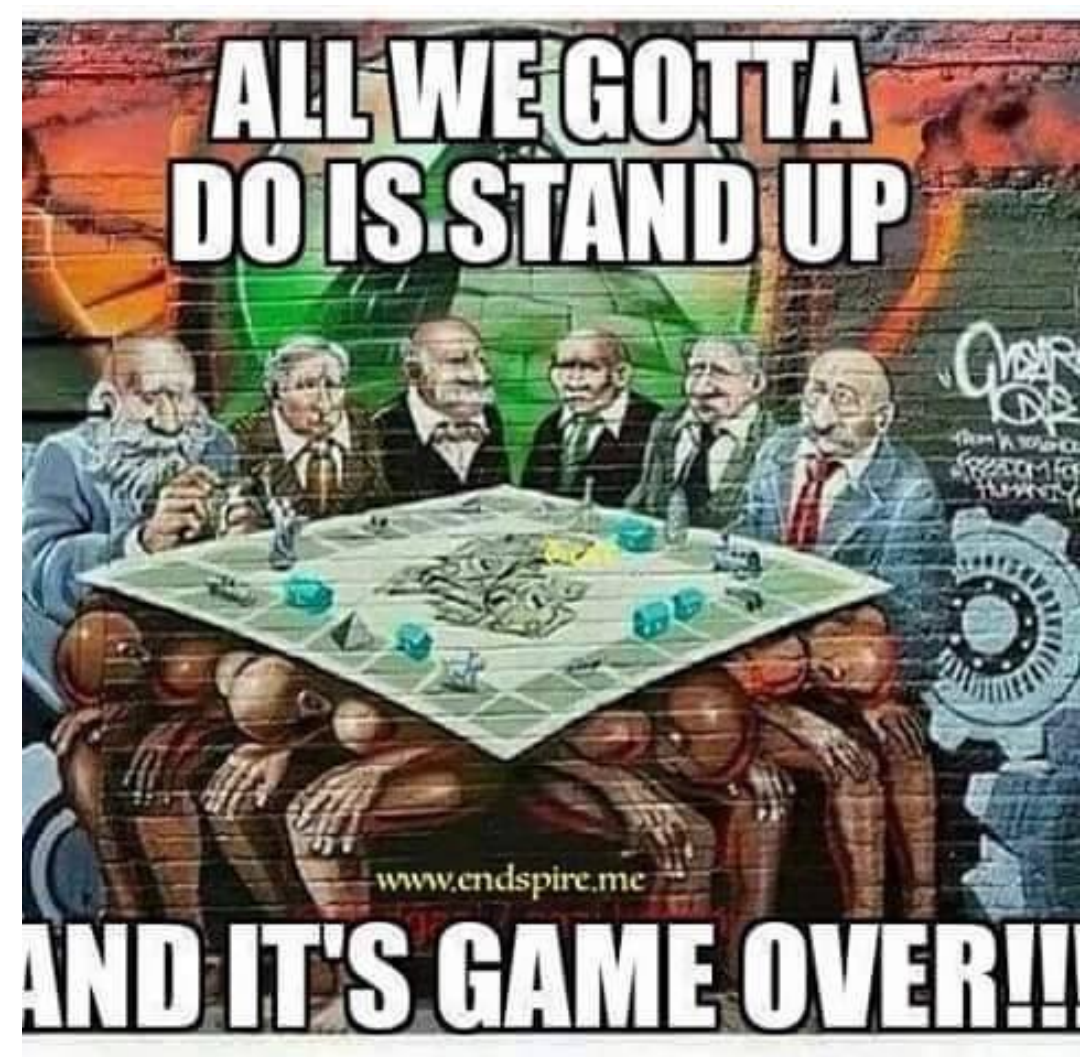




\title{
Resumo
}

Entre julho e outubro de 2015, estive com os moradores do acampamento Canaã, do Movimento dos Trabalhadores Sem-Terra, (MST), localizado em Brazlândia, no Distrito Federal. Inicialmente, fui a campo inspirado pelas discussões da antropologia da criança, no intuito de levar a sério as perspectivas das crianças do acampamento em suas brincadeiras, na ocupação da terra, nas ações políticas do movimento e em seus cotidianos. No entanto, enquanto estive em campo, pude notar que crianças e adultos não eram concebidos a partir de ontologias distintas. Acampados de diferentes idades conviviam na ocupação da terra, no trabalho e inclusive nas brincadeiras. Tal convivência redirecionou as reflexões da pesquisa. Relaciono o ser criança e a brincadeira a uma maneira de pensar, a perceber o espaço e o tempo e a se comunicar que transcende os limites estanques entre adultos e crianças. Assim, o presente trabalho pensa a teia de brincadeiras que envolveram a terra em que o Canaã ocupa, incluindo as brincadeiras do Estado, da Escola e da própria Antropologia que estavam em jogo.

Palavras-chave: ser criança; brincadeira; terra; Estado; tempo

\begin{abstract}
Between June and October 2015, I was with the inhabitants of Canaan, a Workers Landless Movement (MST) encampment, located in Brazlândia in the Federal District of Brazil. Initially, I was inspired by the anthropology of childhood field discussions in order to take seriously the perspectives of encamped children in their play, in the land occupation, in the MST political actions and in their daily lives. However, while I was there, I noticed that children and adults were not designed from different ontologies. Militantes of different ages coexisted in the land occupation, at work and even in play. Such coexistence redirected the research reflections, and allowed me to relate the becoming child and the play to a way of thinking, communicate and relate to the space and the time that transcends the boundaries between adults and children. Thus, this paper thinks the games that involves the land where is encampment Canaan, including State, School and Anthropology.
\end{abstract}

Keywords: becoming child, play, land, State, time. 


\section{Lista de siglas}

CNPJ: Cadastro Nacional de Pessoa Jurídica

DAN: Departamento de Antropologia

DF: Distrito Federal

EIV: Estágio Interdisciplinar de Vivência

FNL: Frente Nacional de Luta

GDF: Governo do Distrito Federal

GPS: Global Positioning System

ICMBio: Instituto Chico Mendes de Conservação da Biodiversidade

INCRA: Instituto Nacional de Colonização e Reforma Agrária

INSS: Instituto Nacional de Seguro Social

MBST: Movimento Brasileiro dos Sem-Terra

MST: Movimento dos Trabalhadores Rurais Sem-Terra

RB: Relação de Beneficiários

SBT: Sistema Brasileiro de Televisão

SEAGRI: Secretaria de Agricultura e Desenvolvimento Rural do Distrito Federal

SINPRO: Sindicato dos Professores do Distrito Federal

TERRACAP: Companhia Imobiliária de Brasília

UnB: Universidade de Brasília 


\section{Sumário}

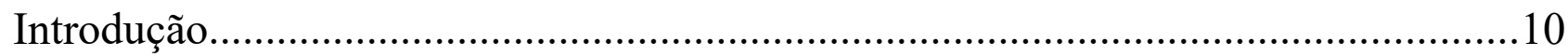

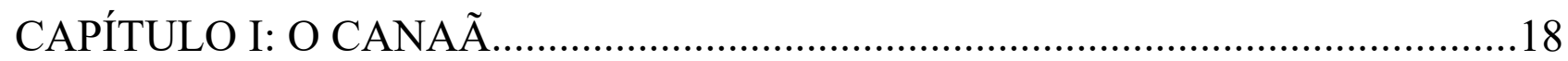

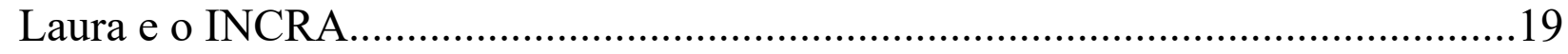

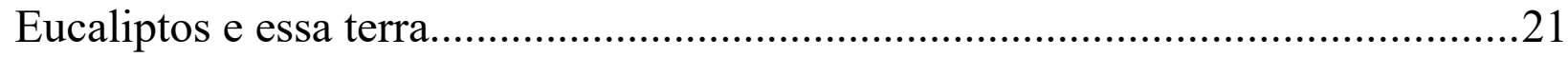

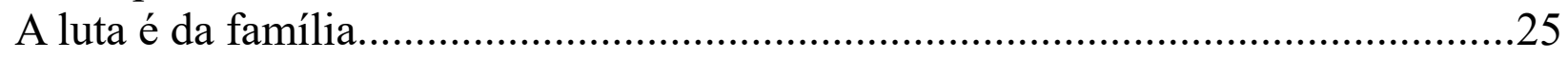

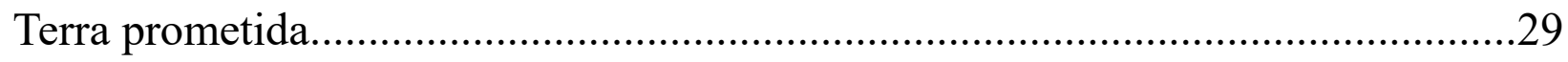

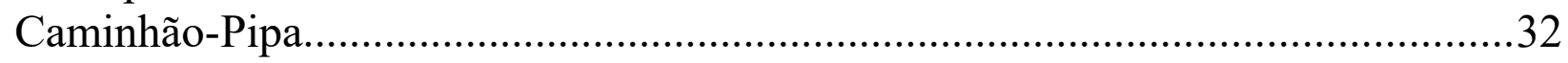

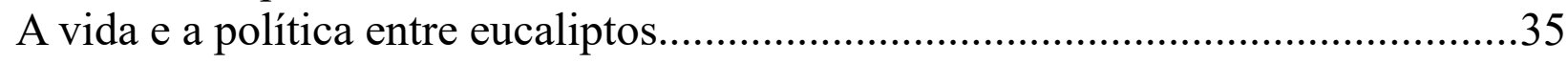

CAPÍTULO II: CAFÉ-COM-LEITE, PIQUES E GIGANTES..................................37

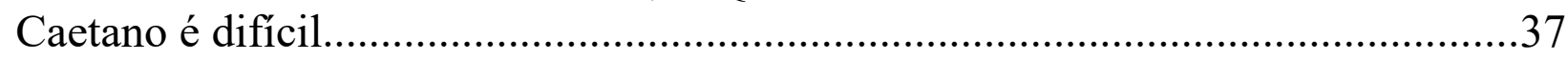

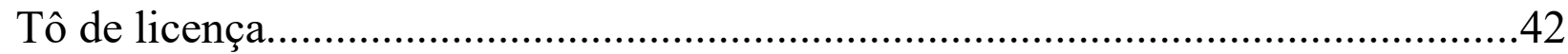

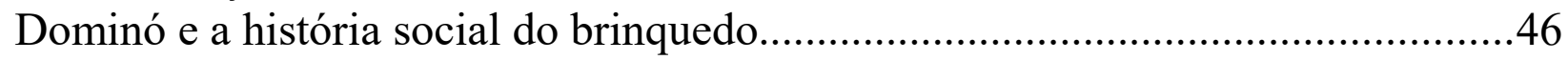

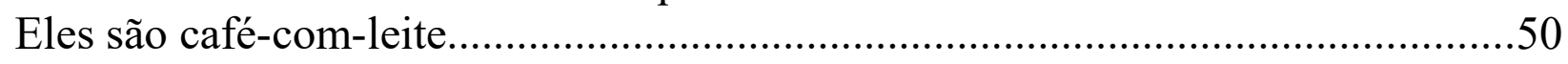

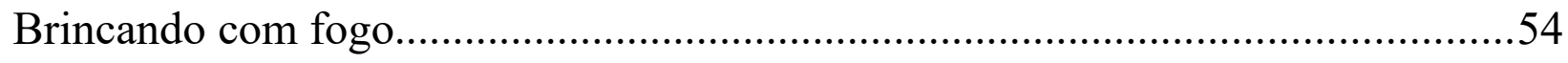

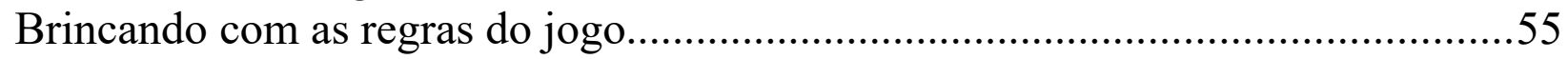

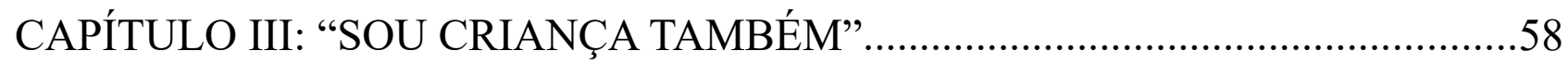

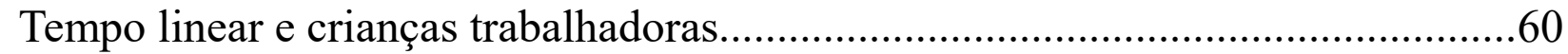

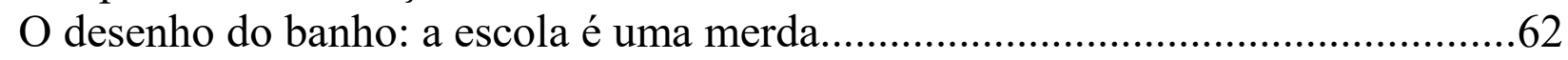

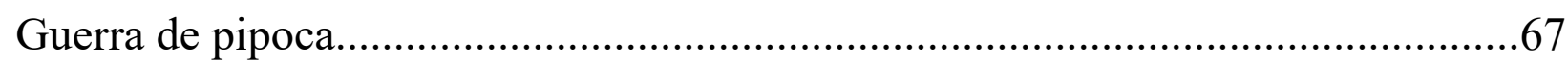

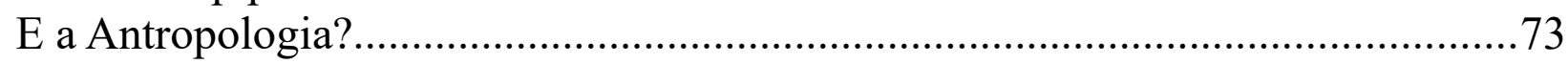

CAPÍTULO IV: REFORMA AGRÁRIA NÃO É BRINCADEIRA..........................77

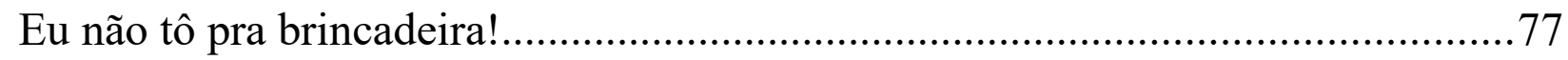

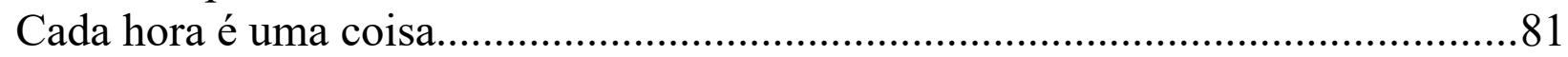

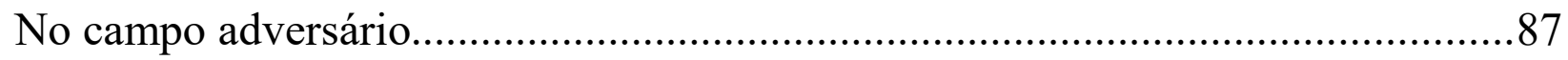

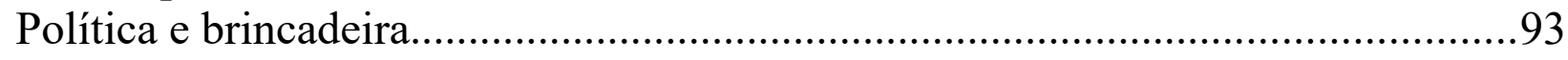

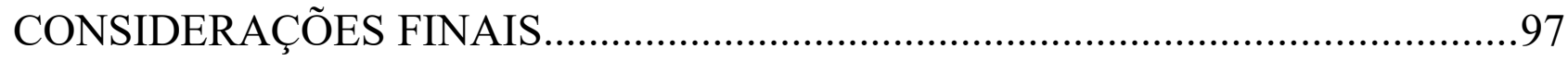

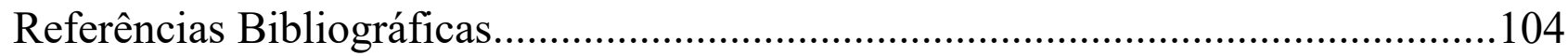




\section{Introdução}

Verônica: E você tá fazendo esse trabalho pra que?

Dona Rita: Pra faculdade, né Gustavo? - Fico um pouco sem graça de notar que o objetivo mais evidente do trabalho era a obtenção de um título e não necessariamente um retorno para elas.

Gustavo: É... eu vou terminar um mestrado, se for aprovado...

Verônica: E você vai ter que falar ou escrever?

Gustavo: Vou ter que escrever mais ou menos umas cem páginas, chamar três professoras e falar sobre o trabalho. Cada professora vai ter mais um tempo para falar o que eles acharam quando leram e depois vou ter mais um tempo para responder. No final elas vão falar se eu fui aprovado ou não.

Dona Rita: Claro que vai. - respondendo com entusiasmo de uma boa anfitriã frente ao meu constrangimento com aquela conversa.

Foi assim que tentei apresentar para Dona Rita e para a adolescente Verônica porquê estava dormindo em sua casa e anotando tanta coisa em um caderninho vermelho. O fato é que não é simples explicar porquê estive no acampamento Canaã, localizado em Brazlândia - DF, de julho a outubro de 2015. É bem verdade que estive lá para finalizar o mestrado e me formar enquanto antropólogo. Mas o que exatamente faz um antropólogo quando vai a campo? O que é agir e pensar como antropóloga ${ }^{1}$ ?

Nesta dissertação fazer etnografia é sinônimo de brincar². Como se verá ao longo do texto, brincar é um verbo de complexidade desconhecida por mim, antes de conviver com as pessoas acampadas no Canaã. Com as crianças, brinquei de queimada, pique-cola, de esconde-esconde e de outras brincadeiras enquanto estive em campo. Todavia, não é somente por ter participado destas brincadeiras que etnografia tem essa conotação aqui. Brincar é entendido por meus anfitriões como uma maneira de pensar. Brincar é movimentar simultaneamente ideias, conceitos, imagens, sons, texturas e sentimentos. Uma criança que brinca de casinha coloca em movimento panelinhas e filhinhos ${ }^{3}$, junto com ideias sobre habitação, família e mesmo sentimentos de raiva, de alegria,

1 Para fugir do masculino universal da língua, também faço o uso do feminino como englobante do masculino em palavras ao longo da dissertação

2 O título desta dissertação,"Brincando na terra", faz referência a essa polissemia relacionada ao verbo brincar. Ao longo da etnografia, fui descobrindo múltiplas maneiras de brincar de crianças e adultos que estavam imbricadas com a ocupação daquela terra. Essa teia de brincadeiras engloba também a atividade do antropólogo em campo. A dissertação trata, portanto, das múltiplas conexões entre as brincadeiras e aquela terra.

3 Borges \& Kaezer (2011) narram a brincadeira de crianças no Recanto das Emas (DF) que consistia em inventar uma cidade com materiais e objetos que as rodeavam. As autoras defendem que as brincadeiras das crianças não circunscrevem-se por uma "experiência naturalista", mas envolvem formas plásticas de "mundos possíveis" e "não necessariamente conhecidos” (BORGES \&KAEZER, 2011) 
tristeza.

Esta maneira de pensar não é restrita às crianças. A antropologia ${ }^{4}$ pode ser entendida enquanto um jogo de deslocamentos e movimentações de ideias e conceitos e sentimentos também. Levando a sério as propostas de Wagner (2009), podemos entender as etnografias da antropologia como um jogo, em que se faz de conta que os outros constituem uma cultura própria, convive-se com as pessoas desta "cultura" por um tempo e brinca-se com os conceitos antropológicos a partir do que é aprendido em campo com os outros ${ }^{5}$. A antropologia movimenta seus conceitos clássicos como se fossem peças de um jogo de xadrez. No lugar de peões, reis e rainhas, a antropologia joga com os conceitos de alteridade, estrutura, cosmologia, poder e parentesco observando os movimentos que os outros fazem em suas outras brincadeiras, em outros tabuleiros.

Também é possível encarar o papel do antropólogo - a sua postura, os prazos, as leituras obrigatórias - como uma brincadeira. Manter a postura de antropóloga - com toda a seriedade que implica fazer esse jogo - faz parte de ser uma antropóloga. Imitar, interpretar e jogar com papéis não estão entre as brincadeiras das crianças? Essa ideia pode ficar mais nítida trazendo as notas de campo de Bascom (1969) sobre a brincadeira de crianças Yorubá usadas no livro de Schwartzman (1978), Nesta nota, o autor narra uma nova brincadeira inventada por estas crianças enquanto ele estava em campo: brincar de Antropólogo ${ }^{6}$. Uma das crianças sentava na cadeira com um papel e uma caneta interpretando o Antropólogo. Uma segunda criança sentava em outra cadeira e era a intérprete. A criança que brincava de ser a intérprete virava-se para uma terceira criança e dizia: “o homem branco quer que você fale a respeito de Odua". A terceira criança a respondia em Yorubá e a intérprete proferia sons sem significado como se falasse inglês para a que brincava de Antropólogo. A criança que interpretava o Antropólogo anotava e tornava a pronunciar sons sem significado para a intérprete, que tornava a perguntar em Yorubá para a que brincava de nativa. Esta brincadeira diz tanto sobre brincar quanto sobre Antropologia (SCHWARTZMAN, 1978).

Por diversas vezes na pesquisa, fiz como a criança brincando de antropólogo no Oeste Africano - fiz perguntas sem sentido para as pessoas do Canaã e anotei coisas no meu caderninho. Acabei me fazendo de antropólogo por mais de uma vez. Como abordarei no restante da

4 Utilizo duas grafias para a palavra Antropologia/antropologia. Antropologia com "A" maiúsculo para designar a disciplina científica e os cânones e a antropologia com "a" minúsculo para se referir às outras discussões sob essa insígnia.

5 "É uma espécie de jogo, se quisermos - um jogo de fingir que as ideias e convenções de outros povos são as mesmas (num sentido mais ou menos geral) que as nossas para ver o que acontece quando "jogamos com" nossos próprios conceitos por intermédio das vidas e ações dos outros.

6 During my work with their fathers these three children invented a new game-playing anthropologist. One sat in my chair or my cushion with paper and pencil in hand. The second sat in their father's chair, acting as "interpreter" while the third sat on a bench as the informant customarily did. The second child turned to the first and said, "You are my master," and then to the third child saying in Yoruba, "The white man wants you to tell about Odua." The third child replied in Yoruba and the second turned to the first and "interpreted," making a series of meaningless sounds which were supposed to sound like English. The first child scribbled on the paper and replied with more nonsense syllables and the second child turned to the third with a new questiona in Yoruba." (BASCON, 1969: 58) 
dissertação, o fato de ser uma brincadeira aqui não se opõe a seriedade das questões em campo e tampouco à política subjacente à vida acadêmica e à produção científica como a praticamos. Somente beneficiado pelo colonialismo (MAFEJE, 1991), pude ir ao Canaã e desenvolver uma pesquisa etnográfica com possibilidades de obter o título de mestre. Ao mesmo tempo, somente com muitos privilégios pude brincar de ser antropólogo e escrever uma dissertação.

A brincadeira no acampamento Canaã começou com uma intenção: estudar "com os semterrinha". Inicialmente, fui movido pela relação entre crianças e política que me fisga desde a graduação (BELISARIO, 2013). Despertei-me para a ação política de crianças logo no início da graduação quando participei do projeto de extensão Política na Escola do Instituto de Ciência Política. Neste projeto, pude ir para a Ceilândia e para a Cidade Estrutural dialogar com crianças de 11 a 13 anos sobre política em escolas públicas entre 2009 e 2012. Em um dos encontros do projeto com outra dupla de monitores, um menino uma vez disse "política é polícia". Em outra oportunidade, na atividade de desenhar "o que é política", uma criança desenhou uma boca em frente a uma lousa, como um professor, e várias orelhas sentadas nas carteiras, como alunos. As ideias fabulosas sobre política que as crianças compartilhavam confrontavam as que aprendia nas salas de aula da graduação em Ciência Política.

A participação no projeto Política na Escola me proporcionou conhecer pessoas que atuavam na Cidade Estrutural e me engajar desde 2011 no Coletivo da Cidade na promoção dos direitos da criança e do adolescente. Lá, pude conhecer outras crianças e adolescentes e ter contato com outras tantas ideias sobre infância, a cidade, consciência negra e mais política. Imbuído destas e de tantas outras provocações, elaborei minha monografia de conclusão de curso discutindo política entre crianças representantes de turma e crianças fofoqueiras em uma escola na Cidade Estrutural. A ação política das crianças, que extrapolava muito o que os professores da escola definiam como restrita ao papel da representante de turma, confrontava diretamente o adultocentrismo da política representativa, mediada por um Estado, que somente reconhece como participação política o voto dos maiores de 18 anos.

Finda minha monografia, segui sendo interpelado pela política com as crianças. Em 2014, participei da Marcha do Movimento dos Trabalhadores Sem-Terra (MST) em Brasília, durante o congresso do movimento. Durante a manifestação, os Sem-Terrinha marcharam ao lado de seus parentes e companheiros, puxando gritos de ordem. No mesmo congresso, as crianças do movimento fizeram uma ocupação no Ministério da Educação em Brasília contra o fechamento de escolas no campo em todo o Brasil ${ }^{7}$. A ação dos Sem-terrinha durante o congresso em Brasília me instigou a refletir sobre a participação de crianças em movimentos sociais. No mesmo ano ingressei no mestrado em Antropologia. A forte carga de leitura e os três semestres de disciplinas acabaram

7 Para saber mais, conferir a reportagem no site $<$ http://www.mst.org.br/2014/02/12/criancas-do-mst-ocupamministerio-da-educacao-por-escolas-do-campo.html $>$ 
por me afastar das atividades na Cidade Estrutural e a não me engajar no MST.

O fascínio pelo tema que me arrebatava com questões e reflexões desde o início da graduação precedeu portanto minha ida ao Canaã. O que eu já tinha lido e pensado a respeito da relação entre crianças e política, com certeza, afetaram a construção e escrita da etnografia. Contudo, as reflexões do mestrado me levaram a problematizar as bases em que este fascínio foi produzido. No segundo semestre de 2014, em uma disciplina ministrada pela professora Antonádia Borges, seis estudantes de antropologia se inspiraram no autor sul-africano Archie Mafeje e aventaram a possibilidade de produzir etnografias a partir de uma proposta "pós-antropológica" (BORGES et al, 2015). Este autor, que lemos durante todo o semestre, nos convida a abandonar os conceitos de alteridade e desvelamento de um Outro cognoscível. A dinâmica da vida das pessoas não permite qualquer conceito analítico que as estabilize em classificações taxonômicas com fins de tornar o que parcialmente cogitamos em retrato fidedigno da vida alheia. Após nossas leituras do Mafeje, assim sintetizamos nossa apreciação de sua obra:

“A dinâmica da vida inviabiliza, para Mafeje, a aposta no caráter perene de categorias analíticas produzidas por investigadores, uma vez que todas as pessoas produzem etnografias. Ao invés de apostar na noção de cultura como algo marcante e englobante de determinada formação social, Mafeje sustenta que existem produções constantes de etnografias, que dialogam entre si, se somam, se anulam, se alternam, se transformam, se englobam e assim sucessivamente. Tais etnografias produzidas pelas pessoas não são separadas em áreas específicas, o que leva Mafeje a defender a produção de pesquisas "não disciplinares", não disciplinadas, mais do que "interdisciplinares" (Mafeje, 2001: 42). (BORGES et al, 2015: 360) ${ }^{8}$

A proposta de Archie Mafeje é muito desafiadora. A pergunta de Verônica, "E você está fazendo esse trabalho para que?", tinha sido antecipada quase um ano antes, quando estava brincando de ser aluno no mestrado. O que eu procurava nos "Sem-Terrinha"? Seriam os SemTerrinha uma cultura? Uma alteridade inventada para viabilizar a minha pesquisa antropológica? Estaria eu pronto se as crianças não falassem de política? Ou, pelo menos, não falassem de política pela linguagem que eu estivesse esperando? Em suma, pensar que as crianças fazem suas próprias etnografias, têm suas próprias questões e brincadeiras pode ser um pouco assustador para quem está se formando para ser um antropólogo fadado à "taxonomização".

Ainda atordoado pelo convite de Mafeje, segui buscando estreitar meus laços com o MST.

8 O uso das citações diretas nesta dissertação não segue um único formato padrão. Algumas das citações diretas estão no corpo do texto enquanto outras estão nas notas de rodapé. Essas padronizações diferentes das citações não têm a ver com uma hierarquia de relevâncias para a construção do argumento. A opção foi pela fluidez do texto quando julguei que a citação no corpo do texto gerava efeitos de quebras no pensamento. 
Em dezembro de 2014, participei do projeto de extensão Estágio Interdisciplinar de Vivência (EIV). O EIV é um projeto presente em várias universidades do país e tem o propósito de aproximar estudantes de diversas áreas com os movimentos que lutam por terra. Pelo EIV, estive pela primeira vez no acampamento Canaã, localizado na Região Administrativa de Brazlândia - DF. O Canaã fica na beira da rodovia DF 445 e do córrego do Rodeador, que dá nome à escola da região. Foi iniciado em 2011 com um número grande de famílias do Movimento dos Trabalhadores Sem-Terra do Distrito Federal (MST - DF), como contam as próprias moradoras. A ocupação ocorreu em um território de plantio de monocultura de eucalipto de uma empresa com a falência decretada. Após muitos anos de pressão por parte do movimento, a empresa pública responsável pelo ordenamento dos terrenos do Governo do Distrito Federal, Terracap cedeu o terreno para o INCRA, que iniciou a formulação de um Projeto de Assentamento. Quando voltei a ir com frequência no Canaã, em julho de 2015, um mapa que marcava os limites das 69 parcelas para as famílias a serem contempladas começava a circular no movimento. Em dezembro, enquanto já escrevia esta dissertação, as pessoas do movimento fizeram o sorteio das terras para as famílias e, em seguida, fizeram a mudança de suas casas construídas próximas umas as outras (acampamento) para as parcelas do assentamento. Entretanto, a portaria que finaliza o processo e garante legalmente o assentamento do Canaã até hoje não foi liberada.

Em julho de 2015, voltei ao Canaã. Como na pesquisa da monografia de conclusão de curso, fui a campo bastante inspirado pela literatura conhecida como da antropologia da criança. A proposta que este campo coloca é de entender que as crianças não são reflexos mecânicos decorrentes de uma socialização unidirecional das adultas, reconhecendo sua agência e negando noções universais de infância (BUSS-SIMÃO, 2009; COHN, 2005 e 2013; TASSINARI, 2009). A primeira ação que tomei foi participar de uma reunião de direção regional do MST para explicar a pesquisa com crianças. Desafiando o antropólogo que insiste em se colocar nas caixinhas, as militantes relataram-me a falta de atividades para idosos e crianças e perguntaram-me da possibilidade de arranjar alguma assistência em saúde para o acampamento. Com receio de criar falsas expectativas sobre mim e preocupado com o "foco" da pesquisa, saí de lá com o compromisso de passar filmes infantis nos fins de semana.

Em um dos fins de semana, levei um projetor e um computador com uma animação e fui de casa em casa chamando as crianças para assistir ao filme. Quando bati na casa de Rosa para chamar as crianças, ela me perguntou: “O filme é só para as crianças? Porque eu sou criança também” E ainda completou: "Você tá aqui pra estudar as crianças? Porque vai ter que me estudar também." Desta vez não pude novamente ignorar uma crítica tão explícita. Não era somente o recorte da pesquisa o que estava sendo julgado, mas o procedimento que me levou a tomar esta via, a ter esses interesses. Que propriedades atávicas existem somente nas crianças que permitem um estudo fazer 
esse recorte? Nunca tinha questionado a existência de uma alteridade entre crianças e adultos. A desestabilização epistemológica de uma mulher também ser criança, do alto de seus 35 anos, me fez novamente refazer a questão sobre o que fazia querendo pesquisar crianças no Canaã. Como procurarei recuperar adiante, aprenderia que os militantes do MST não separavam "ser criança" de ser pessoa na vida em um acampamento - nem separavam essa noção de ser-no-mundo dos eucaliptos, do Estado, da água do banho, da luta da família, dos idosos, da saúde. Se crianças e adultas não eram ontologias completamente distintas, os pressupostos da pesquisa teriam que mudar. Quando ser criança e ser adulta são formados um em relação ao outro, que sentido faz estudar crianças separadamente das adultas? Fazer antropologia da criança daria conta de problematizar a corrente separação entre as pessoas por conta de suas diferentes idades em termos que Mafeje chamaria de "autênticos" (com sentido para meus anfitriões)?

Querendo abdicar das crianças enquanto meu "objeto" sem, com isso, abandonar o que aprendi com as crianças, a saída foi incorporar a provocação de Rosa ao longo de toda a criação da dissertação. Para levar a sério a criatividade de Rosa e das crianças enquanto pesquisadoras, tive que abandonar as disciplinas, como Mafeje sugere, e entender que a potência dos conceitos criados em uma brincadeira ultrapassam a barreira classificatória entre crianças e adultos. Crianças produzem ideias que não precisam se restringir ao entendimento do que é uma "cultura infantil" CORSARO, 2002; SARMENTO, 2005. As reflexões sobre ser criança não podem ser separadas de pensar a terra, o tempo, o Estado. Também foi preciso incorporar as brincadeiras dos adultos na pesquisa, e para isso seria necessário brincar com os conceitos, negar qualquer estabilização analítica. Fazer uma brincadeira etnográfica desobediente. Romper com a linearidade evolucionista que define a criança como o passado do adulto. Topar este desafio tem muitos riscos. Em certo sentido, estas militantes são infantilizados diariamente, sendo tratando como incapazes, iletrados, sem racionalidade. A perspectiva normativa do Estado trata os pobres como crianças, julgando-as incapazes de criar os próprios filhos, incapazes de entender os processos criados pelo próprio Estado. Negando a narrativa da infantilização imbecilizante, pretendo afirmar que as pessoas, a despeito das normatizações do Estado, brincam, assistem desenhos, se movimentam, vivem.

Depois das provocações epistêmicas de Rosa, continuei passando os filmes no final de semana, agora abertos a todos que quisessem assisti-los. No último final de semana de agosto e primeiros de setembro, fizemos sessões de O Menino e o Mundo, Os Sem-Floresta, Vida de Inseto e $O$ Segredo dos animais. A escolha de filmes que abordam temas como política, terra, meioambiente, exploração se deu a partir da expectativa ilusória de discuti-los com as crianças pequenas e grandes como Rosa. Obviamente, era bem mais interessante sair para brincar do que falar sobre o que tinham achado do filme. Logo abandonei essa expectativa e segui as crianças novamente pequenas e grandes, brincando de queimada, pique-cola, pique-bandeirinha, tourinho, 
futebol e tantas outras.

Depois de alguns fins de semana passando filmes, brincando e conversando com as crianças do Canaã, fui recebido por Dona Rita e seus filhos Verônica (16 anos) e Caetano (5 anos), em casa por três semanas de setembro. A confiança da minha anfitriã para abrir a casa a um quase completo estranho como eu foi de fundamental importância para minha presença em boa parte das cenas narradas nessa dissertação. Ficando com essa família, além de brincar mais, tive a possibilidade de participar de atividades políticas do movimento na praça do Buriti (sede do governo distrital), ir em algumas aulas na escola e viver o cotidiano da casa.

Nesta brincadeira etnográfica, tento, em forma de texto, pensar a maneira da criança que brinca de casinha, ou seja, misturando ideias, conceitos, imagens, texturas e sons em um pensamento de faz de conta. Para isso, busco borrar as fronteiras entre realidade e ficção. Os diálogos que apresento nesta dissertação não são transcrições exatas das falas que presenciei no acampamento. Muitos deles são misturas do que foi falado a mim em diferentes momentos e contextos. Alguns deles são inteiramente inventados a partir de conversas e ideias difusas que tive em campo. Tampouco segui a ordem dos acontecimentos na narrativa e sim a ordem que achei que melhor expressaria os aprendizados que tive durante a pesquisa. No Grupo de Estudos em Teoria Antropológica (GESTA), da qual faço parte, chamamos esta metodologia de transcriações. Evidentemente, não é porque contaram com uma dose de minha criatividade que as ideias contidas neste texto são totalmente minhas. A invenção desta dissertação é um esforço de 'criatividade mútua' (WAGNER, 2009), que busca levar a sério as pessoas que encontrei em campo.

Segundo esta metodologia de faz de conta, inventei também as personagens que habitam nestas páginas. Suas características e personalidades são inspiradas em pessoas que conheci no Canaã. Da mesma forma, eu não teria competência para inventá-las sozinho. Além de fazer parte de um borramento entre os limites da ficção e da realidade, a criação de personagens é uma maneira que encontrei para não ser possível identificar crianças que, em muitos casos, trabalhavam - o que é ilegal - e outras militantes que como elas eventualmente não gostariam de ser identificados por suas posições e falas. Com diálogos, personagens e narrações, o Canaã que apresento é uma invenção cujas pretensões, como nos inspirou Mafeje, não são englobar totalmente a realidade.

A maior parte das cenas relatadas neste trabalho foram inventadas a partir de vivências que tive no acampamento Canaã - DF. No entanto, a pesquisa também foi realizada a partir de outros locais. A escola do Rodeador, em que a maioria das crianças e dos adultos do Canaã estudam, foi visitada por três vezes. Também estive por muitas vezes na ocupação da Praça Buriti em frente ao palácio do governador, onde militantes do MST dormiram e fizeram manifestações por cerca de um mês a partir de 21 de setembro. Os acontecimentos na praça também são relatados ao longo da dissertação. 
No primeiro capítulo faço uma apresentação das personagens e uma apresentação geral do acampamento Canaã. A concepção de luta da família, a ansiedade de ganhar a terra, a presença dos eucaliptos e a chegada do caminhão-pipa são elementos muito importantes que balizaram a minha compreensão durante toda a pesquisa. A concepção corrente de luta no Canaã transcende o indivíduo e é importante para a compreensão da participação política das crianças no acampamento.

No segundo capítulo, narro as brincadeiras de que participei. O faz de conta de Caetano me remontou ao argumento de Bateson (1972) sobre a comunicação na brincadeira. Nas movimentações do pique-cola americano, narro como foram evocadas as regras e a organização do espaço. Discuto a convivência entre as diferentes idades na queimada com a participação do cafécom-leite e no "tourinho", brincadeira que aprendi com as crianças no Canaã. Ainda no capítulo II, discuto como as brincadeiras se inserem no repertório político de ocupação de uma praça, de uma terra. Assim, o foco deste capítulo está nas brincadeiras.

No terceiro capítulo, problematizo a noção de tempo e de infância piagetiana da escola. $\mathrm{O}$ que aprendi nas brincadeiras, na escola, na praça do Buriti e no Canaã questiona os fundamentos universalistas básicos de clássicos da Psicologia do Desenvolvimento como Piaget (1976), Freud (1905) e Vygotsky (1991), que não só separam as crianças das adultas como as crianças entre si em diferentes faixas etárias. Em um lugar em que crianças trabalham e que adultos estudam, o tempo linear e a noção de infância da escola não se mostram universais. Abordo outra noção de tempo e do que é ser criança.

No capítulo IV, volto a discutir a luta pela terra dos militantes sob outro prisma. Nas negociações com o INCRA, a morosidade e as idas e voltas do processo de assentamento das famílias gera tensões. A resposta dos acampados é bem nítida: não estão ali para brincadeira. A relação entre política e brincadeira é explorada nesse capítulo. Levo a sério os conceitos que aprendi, como "guardar caixão" e "café-com-leite", para brincar com análise de como o Estado se comporta, com ajuda das reflexões de Herzfeld (1993) e Borges (2004;2014).

Desta forma, inspirado nas pesquisas de militantes do MST - pequenos e grandes - busco não fazer uma etnografia sobre crianças, camponeses ou mesmo sobre o Canaã, mas brincar com uma Antropologia que leva demasiadamente a sério suas classificações e ordenamentos. Talvez seja uma maneira melhor de responder a pergunta de Verônica sobre o que estive fazendo ali por aquelas semanas. Espero ter conseguido. 


\section{CAPÍTULO I \\ O CANÃ̃}

"Quando entrardes na terra de Canaã, esta há de ser a terra que vos cairá em herança, a terra de

Canaã, segundo seus termos" Números, 34.

Agosto de 2015. O tempo estava nublado. As nuvens cinzentas pareciam anunciar o final da estação seca, embora as chuvas só fossem começar de fato dois meses depois. A primeira vez que soube deste acampamento do MST, que ocupava uma área destinada à monocultura de eucaliptos, não imaginei que as casas seriam tão próximas às árvores. No Canaã, as casas das pessoas são exatamente intercaladas entre um eucalipto e outro. $\mathrm{Na}$ entrada do acampamento, a portaria de madeirite dá de frente para a rodovia. Na portaria são dispostos alguns bancos e sofás. Saindo da portaria, um caminho de terra batida perpendicular à rodovia leva às primeiras casas, à vendinha, à plenária, à igreja e a mais eucaliptos. São cerca de cem barracos no acampamento Canaã.

Um menino voltando da escola com sua mochila de rodinhas fez subir a terra fina e vermelha em seu caminho para casa. Os ônibus escolares deixam as crianças na portaria do acampamento. Duas mulheres estavam sentadas em um dos bancos de eucalipto enquanto esperavam o outro ônibus, com seus filhos, chegar da escola. O menino desceu pela terra batida até chegar em frente a plenária. Abaixou-se, pegou um galho seco no chão, jogou o mais longe que conseguiu e seguiu seu caminho até perder-se da vista. Não passou muito tempo e o menino apareceu andando em uma bicicleta ainda vestindo seu uniforme da escola. Essa era a cena em Canaã no fim da tarde daquela quarta-feira.

O Movimento dos Trabalhadores Sem-Terra (MST) surgiu no começo da década de 80 . Desde então, o movimento vem ocupando terras e fazendo acampamentos por todo o Brasil na luta por reforma agrária. O movimento é composto por instâncias que se organizam em cada acampamento e assentamento em que o MST está presente. Cada um dos acampamentos possui núcleos de base e assembleias que discutem a política a ser implementada pelo movimento.

Depois de haver me feito conhecido na reunião de direção regional, era hora de falar na assembleia sobre o que eu faria tão frequentemente ali pelos meses seguintes. A assembleia do Canaã só seria às 20 horas, o que me dava algumas horas para circular pelo acampamento. Mal sabia eu que a expectativa era grande para aquela assembleia, a primeira de que participei no Canaã, e que tal expectativa divergia muito da que eu mesmo tinha a seu respeito. 
O Canaã era uma ocupação de mais de cinco anos. Naquele dia porém, pela primeira vez, as militantes poderiam ver a proposta de mapa do assentamento. Muita luta aconteceu no Canaã para que a terra pertencente a uma empresa de produção de eucaliptos fosse finalmente dividida em um mapa de parcelas. As famílias almejavam um pedaço daquele chão que ocupavam, uma parcela de terras feita um pouco mais concreta porque demarcada no mapa elaborado pelo INCRA. Os meses subsequentes mostraram que muita luta ainda estava por vir para "cair para as parcelas", ou seja, morar na área riscada no chão, indicada pelo desenho naquele papel.

Esta, como discuto, seria uma dentre as muitas, incessantes e cotidianas lutas que mulheres incríveis levariam a cabo por entre os eucaliptos. Além de mover mundos para cair para as parcelas, elas criariam os filhos, pegaram a água do caminhão-pipa, vendo eucaliptos sendo removidos de forma descuidada, colocando em ameaça a integridade de seus corpos, colocando em risco suas vidas e apostas no futuro. Neste capítulo, tento apresentar o Canaã a partir do que aprendi com essas mulheres, através das personagens Laura, Eliana, Dona Rita e Rosa. Como disse na introdução deste trabalho, a ficção e a invenção de personagens têm um propósito metodológico de não identificar militantes de um movimento recorrentemente criminalizado, além de ter como inspiração a metodologia de um faz de conta.

\section{Laura e o INCRA}

Naquele dia, encontrei Laura na vendinha. Lá compra-se salgadinhos, pirulitos, biscoitos e outros produtos industrializados. A vendinha não tem um proprietário. Os moradores se revezam na tarefa de trabalhar nela, apesar de eu só ter visto Tião desempenhando essa função. O dinheiro ali apurado é usado para financiar as ações do movimento. Localiza-se em um dos primeiros barracos na entrada do acampamento, entre uma casa e a edificação onde fica a plenária. Laura é uma mulher negra, de baixa estatura, que tem por volta dos seus quarenta anos. Conheci Laura durante minha estadia no Canaã pelo EIV. É uma militante de grande assertividade na vida política do Canaã. Mora com seu marido João, sua filha Cleonice (11 anos) e seu filho Victor (4 anos). Ela foi a primeira pessoa a me explicar o processo daquela terra no INCRA:

Gustavo: Você vai na reunião hoje, Laura?

Laura: Não perco essa reunião por nada! Hoje vão mostrar o mapa que o INCRA fez.

Gustavo: Mapa? Pra reforma agrária já? - a minha surpresa não deixava de ser conflitante com a percepção de quem havia ocupado a terra há tanto tempo. 
Laura: Isso. Agora só vai faltar fazer as marcações no chão mesmo.

Gustavo: E vocês já sabem onde fica a parcela de cada um?

Laura: Não, ainda tem que ter a lista de quem vai ficar.

Gustavo: Mas vocês já não tem a lista?

Laura: Não. O movimento fez uma com os critérios do movimento. O movimento vê quem tem luta. $\mathrm{O}$ do INCRA é pra ver se enquadra em Produtor Rural. Se tem CNPJ, não pode receber terra. Se tem renda acima de três mil reais não pode, se é aposentado por invalidez, não pode... Aí quando tem a lista do INCRA, a gente já sabe quem vai para as parcelas.

Durante a pesquisa de campo, na reta final do processo de assentamento das famílias do Canaã, as menções ao INCRA e às reuniões com o órgão foram frequentes. O Instituto Nacional de Colonização e Reforma Agrária (INCRA) é uma autarquia estatal responsável pela gestão da política de reforma agrária no Brasil. Castro (2015) narra as diversas transformações que a autarquia passou desde a sua criação em 1970, quando o projeto prioritário tocado pelo órgão era de colonização da região amazônica, por meio de deslocamento de trabalhadores rurais de outras regiões do país. A partir da redemocratização, em meados dos anos 80 , o INCRA teria se voltado prioritariamente para a reforma agrária. Desde então, a negociação com os movimentos sociais de luta pela terra, como o MST, passou a ser parte do trabalho cotidiano do INCRA. Os repertórios e instrumentos de luta pela terra, como é o caso do acampamento, passaram a ser incorporados como parte da rotina do INCRA, na gestão da política de reforma agrária (CASTRO, 2015).

Nessa interlocução com o INCRA, os movimentos sociais apresentam as propriedades a serem desapropriadas e a lista de famílias acampadas que demandam a terra (CASTRO, 2015). Muitas vezes o fazem por meios diversos, sendo o mais eloquente, o acampamento (SIGAUD et al, 2006). Quando conversei com Laura, no mês de agosto, o MST já tinha feito a lista com as sessenta e nove famílias que deveriam ser contempladas com o parcelamento do Canaã. Porém, como depreendemos do diálogo acima, não basta que o movimento apresente os nomes de quem deveria ser contemplado. O INCRA faz uma avaliação dos nomes da lista dada pelo movimento e identifica se as propriedades ou qualidades daquelas pessoas cumprem com os pré-requisitos legalmente exigidos do chamado público-alvo da política de reforma agrária. Segundo o site do INCRA ${ }^{9}$, não são podem ser contemplados pela política de reforma agrária: funcionários públicos; candidatos com renda familiar acima de três salários-mínimos mensais; donos ou sócios de empresas ou indústrias; proprietários de imóvel rural superior a um módulo rural; portador de doença física ou 
mental que o torne impossibilitado para o trabalho agrícola; estrangeiro não naturalizado; aposentado por invalidez; condenados pela justiça com pena pendente ou não prescrita.

A Relação de Beneficiários (RB), ou seja, a lista de famílias oficialmente contempladas no assentamento, fica pronta findada a avaliação da lista dos movimentos sociais a partir desses critérios. Em agosto, as sessenta e nove famílias indicadas pelo MST já estavam definidas. Como contarei na dissertação, a Relação de Beneficiários elaborada pelo INCRA demoraria para sair, mais do que as famílias estavam esperando.

Gustavo: E a terra vai até onde?

Laura: Vão até lá embaixo. Toda essa área que era da Proflora. São 363 hectares. Cinco por família. Gustavo: Proflora?

Laura: É. Proflora era a empresa que faliu. Aí tinha uma dívida com o governo e o governo ficou com os eucaliptos.

Gustavo: Ahhhh. Eu achei que os eucaliptos eram da empresa.

Laura: É que o governo vendeu os eucaliptos para uma empresa que tá tirando.

Laura está na ocupação desde seu início, em 2011, quando o MST ocupou a terra que pertencia a Proflora. Ela e outros militantes me disseram que o acampamento "parecia um formigueiro", de tanta gente que participou da ocupação. Centenas de pessoas foram para o Canaã na esperança de conseguir uma terra. Segundo Laura, foi sua prima que a convenceu a ir para o acampamento com a promessa de fugir do aluguel em seis meses. Muita gente teria desistido da ocupação no primeiro ano, quando o acampamento ainda não tinha luz e nem água. Outros se mudaram para outros acampamentos ou foram assentados em outras terras. Quando conheci o acampamento Canaã, em dezembro de 2014, o acampamento contava com cerca de 120 famílias. A divisão da terra no mapa feito pelo INCRA estabelecia, no entanto, sessenta e nove parcelas.

\section{Eucaliptos e essa terra}

Depois de me despedir de Laura, andei em direção à plenária para aguardar a assembleia. Como dito, o espaço da plenária fica ao lado da vendinha. É lá onde são feitas as reuniões e assembleias do Canaã. Quatro toras de eucalipto seguram o telhado da plenária. Não existem paredes o que torna possível que pessoas do lado de fora possam acompanhar reuniões muito cheias. No lado de dentro, contornando o espaço coberto pelo telhado, há mais toras de eucalipto, 
usadas como banco. A mesa de madeira fica no canto e raramente é utilizada. Eu aguardava do lado de dentro. Eliana passou com seus filhos mais novos Leonardo ( 9 anos), Luisa (5 anos) e Luã (3 anos) do lado de fora:

Eliana: Você não é o menino que vai passar o filme das crianças?

Gustavo: Sim. Sou eu sim.

Eliana: Seja bem-vindo ao Canaã; - Eliana vem a minha direção e senta ao meu lado - meu nome é Eliana.

Gustavo: Prazer Eliana. Meu nome é Gustavo.

Luisa: Eu sou a Luisa. O que você é?

Gustavo: Eu sou antropológo.

Luisa: A gente é evangélico.

Eliana é uma mulher alta, corpulenta e expressiva. Nos atos, é ela quem é a mais animada em puxar as músicas do movimento. Sabe todas de cor. Eliana também é muito religiosa. Não foi raro encontrá-la levando uma bíblia entre os braços. Ela mora com seus cinco fillhos no Canaã. Luã, Luisa e Leonardo são os mais novos. Além deles, Eliana é mãe de Lucas e Lorena. Luisa tem o cabelo preto e cacheado. A menina não gosta de ir à escola. Costuma chorar antes de ir. Ela brinca bastante com Luã, o mais novo dos cinco. Ele tem três anos e adora brincar na terra, para desespero da mãe. Leonardo tem nove anos. Ele gosta de jogar futebol, queimada e videogame, assim como o irmão mais velho Lucas, de doze anos. Os dois são conhecidos por arranjarem brigas quando brincam com as outras crianças no Canaã.

Eliana: Tá mais calma agora Luisa? - Luisa saiu de perto da mãe e foi brincar com os dois irmãos. Eles começaram a brincar com uma bola, tentando acertá-la por cima da armação de madeira que sustenta o telhado. Eliana se vira para mim e diz - Hoje ela fez uma birra na hora de ir pra escola! Arrumei o Lucas, o Leonardo... a Lorena tava doente e não foi. Quando foi a hora de dar banho nela, não queria entrar de jeito nenhum. Fez uma birra, mas uma birra que aí não foi. E logo hoje que era passeio pro filme. Ô Luisa, se não fizesse aquela birra ia para o passeio da escola.

Luisa seguiu brincando com a bola e seus dois irmãos como se não tivesse ouvindo a mãe. Leonardo subiu em cima da mesa, tentando acertar a bola entre a armação e o telhado.

Eliana: Desce daí menino! - Leonardo desce da mesa e senta ao lado da mãe. 
Gustavo: Como foi o passeio da escola hoje?

Leonardo: Foi chato... Não, teve coisas legais e coisas chatas. Teve um acidente no caminho. O carro ficou todo amassado lá nas Águas Claras.

Gustavo: E o filme?

Leonardo: Foi Divertida mente ${ }^{10}$. O filme é chato.

Gustavo: Como ele é?

Leonardo: É dos sentimentos que tem... A raiva, a tristeza, o nojo, o medo... E os pais dela também têm todos.

Eliana: Gustavo, você tá esperando a assembleia é?

Gustavo: É.

Eliana: Menino, isso vai demorar ainda. Vamos lá em casa tomar um café.

Aceitei o convite de Eliana e fui com ela até sua casa. O barraco é feito de madeirite e tem dois cômodos. Na sala, um sofá e uma mesa de jantar dividem o espaço com os armários, fogão e geladeira da cozinha. O outro cômodo é o quarto de Eliana e de seus filhos. Neste quarto ficam duas camas de casal e um armário. Lucas e Lorena estavam na sala. Lucas estava fazendo o dever de casa do colégio na mesa de jantar, enquanto Lorena no sofá mexia no celular. Lorena é a mais velha dos cinco: tem 14 anos. Seu cabelo é tingido de rosa nas pontas. Os mais novos, Lucas, Luisa e Luã, entraram no barraco, sempre brincando com a bola.

Eliana: Senta um pouquinho, Gustavo, enquanto eu passo o café. - sento ao lado de Lucas e seu dever de casa, mesmo com receio de atrapalhá-lo. - Será que vai voltar a chover agora?

Gustavo: Tomara que sim. Tá muito seco!

Eliana: É. Tá precisando molhar a terra mesmo. Mas eu morro de medo de chuva forte. No meio desses eucaliptos aqui? Uma vez um deles caiu aqui no meio do meu barraco. Lucas e Leonardo estavam jogando videogame no quarto. Imagina se tivesse caído lá? Deus me livre!

Gustavo: Mas ele caiu com a chuva?

Eliana: É. Tem uns que tão mais velhos, tão envergando já. Aí molha, venta, eles caem mesmo. Isso quando a empresa que tá tirando não os derruba aqui perto.

Gustavo: A empresa já tá tirando é?

Eliana: Há muito tempo! Mas eles disseram que iam começar nas partes longe das casas. Agora dizem eles que terminaram pra lá e começaram a derrubar os daqui, que não tem risco. O INCRA

10 Divertida mente é uma animação que esteve em cartaz nos cinemas em 2015. O filme acompanha o crescimento de uma menina na perspectiva de suas emoções, internas a ela. 
queria que a gente desmontasse o acampamento e montasse em outra área que não tem mais eucalipto. A gente não quis não. A gente disse que só sai daqui para ir direto pras parcelas. A empresa quer tirar [os eucaliptos] de todo jeito [com ou sem a presença das acampadas e seus barracos].

Gustavo: Que perigo!

Eliana: A gente quer que tire quando a gente sair daqui. Só não quero que ele caia em nenhuma criança aqui, pelo amor de Deus. Mas tem que tirar. Eles acabam com o solo. Puxam toda água pra eles. Fica ruim de plantar.

Gustavo: Mas tem gente que planta assim mesmo né?

Eliana: Eu planto aqui. Vem ver...

Eliana me levou para fora da sua casa para mostrar o que planta, entre um eucalipto e outro. Milho, feijão, abóbora e outras plantas que só fui conhecer no Canaã: taioba, imbú, vinagreira. “As plantas que são dessa terra mesmo" disse ela, em contraposição à extensa monocultura de árvores exógenas. A despeito do eucalipto ser muito alto e suas folhas fazerem muita sombra, Eliana coloca as sementes na terra. Apesar do solo duro e do eucalipto puxar muita água, Eliana rega e aduba as plantas. A despeito da monocultura, crescem outras coisas no acampamento Canaã. Aos poucos, os eucaliptos vão sendo tirados dali. A maior parte deles é vendida a preço de mercado e transforma-se em carvão vegetal, madeira, lenha ou celulose (CARDOSO \& PIRES, 2009). Outras árvores se transformam em bancos, igrejas e barracos e continuam a conviver no próprio Canaã.

A relação entre as plantas “dessa terra” e os eucaliptos não são uma questão menor na luta política do Canaã. Comaroff e Comaroff (2001) narram como após um fatídico incêndio na Cidade do Cabo, a opinião pública sul-africana voltou-se contra às plantas estrangeiras, ditas mais inflamáveis do que as locais. Para os autores, a comoção da nação em reação às árvores alienígenas - de terras distantes como os eucaliptos da Austrália, por exemplo - e a exaltação da vegetação autóctone - como as proteas, símbolos da nação sul-africana - foram uma expressão da xenofobia no país. Comaroff e Comaroff (2001) argumentam que esta reação às plantas estrangeiras é decorrente da fase do capitalismo neoliberal global corrente, na qual a falta de alternativas ideológicas e sistêmicas induz à despolitização da política, "e seu deslocamento do reino do social e do cultural, moral e ideológico" (COMAROFF\&COMAROFF, 2001: 98) para o mundo "natural”.

O apreço que Eliana demonstra às plantas "que são dessa terra mesmo" me parecem ser muito diferentes de reações xenofóbicas que estes autores sul-africanos identificam como despolitizadas. Primeiro, porque a monocultura de eucaliptos em Brazlândia não se restringe a um mundo natural deslocado do reino social. Estes eucaliptos foram plantados por uma empresa com o 
objetivo de gerar lucro. A dinâmica da economia capitalista levou a empresa à falência e à permanência das árvores naquela terra. A ocupação da terra por um movimento social forçou o Estado a vendê-las e circulá-las como mercadorias. A demora do INCRA em fazer reforma agrária mantém os eucaliptos e seus perigos para as famílias. Os efeitos dos eucaliptos na vida dos acampados não separa mundo natural e mundo social. Economia de mercado, política de reforma agrária e monocultura de eucaliptos fazem parte de um todo articulado que mata plantas, puxa toda água e destrói barracos, ameaça vidas.

A segunda razão que afasta Eliana de reações xenofóbicas e despolitizadas apresentadas por Comaroff e Comaroff (2001) é a concepção "dessa terra”, que ela apresentou. O milho não é uma espécie com origem no Brasil, assim como a vinagreira não tem origem nas Américas - se é que faz algum sentido falar em origens geográficas de fauna ou flora. Os eucaliptos, no entanto, não fazem parte "dessa terra". Por outro lado, a plenária, a igreja, os barracos e cercas feitas com as toras dos eucaliptos não são de outra terra, mas dali mesmo. "Essa terra" de que nos fala Eliana seria uma categoria plástica, aberta, capaz de (se) transformar, incorporar, se fundir. A monocultura de eucaliptos não pode ser "dessa terra", uma vez que mata todas as culturas que a rodeiam. Acredito que quando Eliana fala em plantas "dessa terra", ela se aproxima mais do que Mafeje $(1971,1991)$ entende por endógeno, em contraposição a exógeno. Menos do que uma aposta entre uma distinção essencialista que separa "dentro" e "fora", Mafeje chama de exógenas as categorias que, de tão auto-evidentes, não buscam se relacionar e conviver de nenhuma forma com o que já estava naquela terra anteriormente. Assim como a monocultura de eucaliptos, tentam deixar terra arrasada e homogeneidade por onde passam.

Eliana nos mostra que não necessariamente é menos politizado envolver plantas no debate sobre luta por um chão, por um solo. A valorização daquilo que é "dessa terra" é um combate a destruição proporcionada pela monocultura de eucaliptos e pela ineficiência na política de desconcentração de terras. A luta de Eliana em meio aos eucaliptos e o pensamento de Mafeje acerca do endógeno e do exógeno voltarão a aparecer enquanto inspiração metodológica no restante da dissertação.

\section{A luta é da família}

Quando deu a hora da assembleia, Eliana, Leonardo, Luisa e Luã me acompanharam até a plenária. Lorena não quis ir e Lucas ficou fazendo o dever de casa. Na plenária, encontramos Laura com seus filhos Cleonice (11 anos) e Victor (4 anos). Perguntei a Cleonice se ela não achava chato 
vir à assembleia. Ela respondeu que acha legal porque é quando as mães e os pais das crianças deixam elas brincarem juntas no turno da noite.

Aos poucos, mais militantes foram chegando à assembleia. Quando era 20:15, Eliana começou a cantar "E já estamos nessa terra e não vamos sair, nosso lema é ocupar, resistir e produzir." O resto da militância ${ }^{11}$ acompanhou Eliana a partir do segundo verso. Cleonice, Verônica, Leonardo e Luisa batiam palmas e cantavam junto. As militantes cantaram o hino do movimento e rezaram o Pai-nosso. Finalizada a oração, começaram a pauta da reunião:

Chico: Então pessoal. Ontem tivemos a reunião no INCRA e finalmente temos o mapa da divisão das parcelas aqui do Canaã. Ficaram as sessenta e nove parcelas mesmo como eles tinham nos dito, mais a Área Comum lá embaixo. Vai ter uma reunião agora com o ICMBio [Instituto Chico Mendes] porque a gente tá vendo a possibilidade da nossa Reserva Legal ser externa ao assentamento. Parece que vai rolar. O que tá faltando agora? Falta o INCRA fazer as marcações no chão e entregar a Relação de Beneficiários, a RB, pra gente. Todo mundo aqui tem que tá consciente do risco dos nomes que o movimento enviou poderem ser derrubados pela relação do INCRA. Falta também a gente discutir o caso da família do Pastor, se vai ficar com a terra ou se a gente pode colocar outra pessoa que não foi contemplada, mas que tem luta.

Algumas folhas com o desenho do mapa do assentamento circularam pela plenária durante a fala de Chico. Grupinhos se formaram ao redor de cada um dos mapas. A militância olhava de canto de olho a disposição das parcelas no mapa, imaginavam o tamanho da terra que cada contemplado conseguiria, identificavam as parcelas com localização mais privilegiada e as mais remotas.

Verônica chamou Cleonice e as duas saíram da plenária. Os filhos de Rosa, André, Kethlen e Felipe, seguiram as duas meninas. As cinco crianças fizeram uma roda do lado de fora da plenária, onde a luz estava escassa. De repente, Cleonice foi em direção a um eucalipto, escorou seu braço direito na árvore, aninhou seu rosto no braço e começou a contar. As outras crianças correram e se esconderam. A assembleia seguiu, com a Laura pedindo a palavra:

Laura: Queria lembrar todo mundo aqui...

Chico: Desculpa Laura. Calma aí. Desculpa. Antes de você falar, o Gustavo queria se apresentar aqui pra vocês. Ele foi na última reunião da Direção Regional e vai fazer uma pesquisa aqui no Canaã. Se apresenta aí Gustavo. - não queria ter atrapalhado a fala, mas levantei mesmo assim.

11 Militância é um termo utilizado nos movimentos sociais para designar o coletivo presente. Seu uso engloba inclusive as pessoas que não são tão envolvidas com as ações do movimento. 
Gustavo: Olá. Meu nome é Gustavo Belisário. Estou fazendo o mestrado em Antropologia da UnB e vou vir bastante aqui nas próximas semanas. Faço pesquisa com crianças. Combinei na reunião da Direção de passar filmes aqui no Canaã nos fins de semana para as crianças. Não quero atrapalhar a reunião mais. Aos poucos a gente vai se conhecendo melhor.

Chico: Obrigado, Gustavo. Seja bem-vindo. Laura, pode retomar sua fala.

Laura: Seja bem-vindo, Gustavo. Eu queria lembrar vocês da luta do Pastor aqui. Quantas ocupações de terra, de órgão que a gente foi e o Pastor tava lá. Infelizmente ele veio a morrer. Mas a luta não é da família? Eu acho que a filha dele merece ficar com a terra e continuar a luta que o pai dela começou. O pai dela tinha luta pra isso. Outra coisa, eu acho que a gente podia já ir adiantando essas coisas das marcações. Se a gente for esperar os marcos do INCRA... Melhor a gente já fazer os marcos nós mesmos.

Chico: Agora, Tião.

Leonardo se escondia atrás da parede da vendinha. Cleonice andou na outra direção procurando alguma criança camuflada entre eucaliptos. Dentro da plenária, Luã dormia no colo da sua mãe, enquanto Luisa brincava com Victor. Luisa cobriu a cabeça de Victor com um saco de pipocas e o menino o tirou logo em seguida. Os dois riram bastante e repetiram a brincadeira. Tião começou a sua fala:

Tião: Eu acho que o companheiro que tem luta, a direção tem que lutar por ele. Tô falando do que não tiver na lista do INCRA e que tem luta. Os que não têm luta ninguém tá discutindo. Se meu nome não entrar naquela lista, eu vou querer que a direção lute por mim, que a gente encontre algum jeito. A luta é da família. Se o nome do Tião tiver sujo, porque sou feio, sou maconheiro, ressuscito minha avó lá do Juazeiro pra gente colocar o nome dela.

Leonardo correu, tocou no eucalipto que Cleonice estava contando e gritou "um, dois, três, salve eu". Cleonice voltou correndo e grita "Felipe tá pego". Laura sai da plenária e diz "Cleonice! Se continuar a atrapalhar a reunião você vai direto pra casa! Fala mais baixo!’. O corpo de Cleonice franziu e a menina voltou para onde estavam as outras crianças. Não passou muito tempo, elas estavam novamente rindo e brincando de esconde-esconde.

As brincadeiras compartilharam o espaço da plenária ao longo de toda assembleia. Como dito, quando as mães e os pais estão na assembleia, as crianças podem brincar juntas em um momento pouco usual: a noite. Ao brincarem durante a discussão da assembleia, as crianças tiveram que tomar cuidado para não atrapalhá-la. O barulho não podia desconcentrar os participantes da 
assembleia. Correr no meio da plenária chamaria atenção em excesso para a brincadeira. Atrapalhar a assembleia poderia culminar no fim do esconde-esconde. É no limite entre ser ouvido e fazer muito barulho, ser visto e chamar muita atenção, que as brincadeiras concomitantes com a assembleia podem ocorrer.

Eliana: Queria dizer que eu concordo com a Laura de que a filha do Pastor merece a terra pela luta do pai dela. E concordo com o Tião: a direção tem que lutar por nós. Mas tem casos e casos aqui dentro. Tião, eu sei que você tem luta. Mas tem gente aqui dentro que não sabe o que é ter medo desses eucaliptos caírem em cima do seu barraco porque não mora aqui. Só vem de fim de semana. Tem gente que não sabe o que é criar os filhos aqui no meio da terra, o sofrimento que nós passamos morando aqui. Que acha que só porque de vez em quando vai nas atividades do movimento fora do acampamento faz luta. Enquanto isso, é nós aqui que estamos morando e garantindo o Canaã ocupado. Então, se a direção for lutar por essas pessoas, tem que saber que teve mãe que criava os filhos aqui do nosso lado e que não foi contemplada na lista do movimento. Sobre a marcação, concordo com a Laura. Alberto e Chico não podem fazer isso não?

Alberto: Eu posso. Só tem que recolher o dinheiro então.

Chico: Recolhe no fim da assembleia, Alberto

Várias falas mobilizaram o jargão "a luta é da família" em diferentes sentidos durante a assembleia. A filha do falecido pastor Matheus tinha para Laura e Eliana direito à parcela mesmo que ela não tenha aparecido em nenhuma ação do MST. A participação de seu pai nas ações do movimento contaram como luta que não podia ser ignorada por sua morte. A luta dele valia para ela também. Tião argumentou que a luta que ele fez não poderia ser desperdiçada caso seu nome fosse excluído da Relação de Beneficiários do INCRA. Se a luta é da família, sua avó poderia receber em seu nome a parcela pela luta do neto. Eliana alerta que buscar água, criar os filhos entre os eucaliptos, levar as crianças nos atos faz parte da luta também. Uma luta enfrentada por toda a família para continuar ocupando o acampamento.

A luta da família não está entre os critérios do INCRA para o acesso à terra, mas, na visão das moradoras, ela é um critério essencial para a montagem da lista que o movimento apresenta para ser avaliada pelo INCRA. Quem tem luta consegue legitimamente pleitear terra pelo MST. Troca-se luta da família por um nome na lista do movimento. O nome na lista é individual. Os prérequisitos exigidos e avaliados pelo INCRA são intransferíveis e devem ser comprovados com a documentação referente àquela pessoa. No entanto, a luta é coletiva e se espalha entre as pessoas que participam dela. A substância luta é compartilhada por toda a família. 
Nos termos de Strathern (2006), a família seria um "compósito", que contém dentro de si toda a luta feita pela família. É a ela que a luta pertence. A luta da família aponta para uma participação no movimento que transpassa e ultrapassa o indivíduo. Um dos sentidos desse fluxo nos leva a uma reflexão sobre o tempo. "A luta é da família" aponta para um engajamento que perpassa as gerações. A conquista da terra perdura ao longo dos anos - para frente/futuro e para trás/passado - atravessando e conectando filhos, netos, bisnetos. Remete à luta de mães, pais e avós, mas também de crianças. Lembra em suma que embora aparentemente se trate de uma luta de pessoas singulares, essa não deve ser reduzida a um empenho ou projeto individual.

\section{Terra prometida}

Nas semanas seguintes, passei os filmes nos fins de semana. Depois de cada filme, as crianças iam para o campinho, que fica ao lado da igreja, brincar. A aproximação com as crianças se deu principalmente nas brincadeiras que se seguiram aos filmes do que através dos próprios filmes. As reflexões com as crianças e das brincadeiras serão narradas de forma mais cuidadosa nos próximos capítulos. Sigo neste capítulo com uma apresentação das mães e do acampamento.

Acabei me afeiçoando mais por algumas militantes. Como com Laura, Dona Rita foi um desses encontros que acabaram em afeto. Dona Rita cresceu no interior da Bahia. Ela falava pouco nas reuniões, a despeito de manter uma boa relação com todas as acampadas. Morou por um tempo perto de Taguatinga com seu marido. Achou muito barulhento viver por lá. Mudou-se para o Canaã no início do acampamento. Boa cozinheira, Dona Rita foi uma das responsáveis da cozinha quando o movimento fez a ocupação na praça do Buriti, de que tratarei no capítulo II. "Não largo mais essa confusão aqui não" diz ela sobre o MST. Por três semanas em setembro, dormi na casa de Dona Rita. Sua acolhida foi fundamental para a pesquisa e para o afeto entre sua família e mim.

Atualmente, Dona Rita mora com os dois filhos mais novos, Verônica (16) e Caetano (5), no Canaã; enquanto o marido mora com os dois filhos mais velhos em Taguatinga - DF. Caetano é um menino levado. Seu cabelo mais claro lhe rendeu o apelido de "galego" no acampamento. O menino está sempre brincando de alguma coisa. Ele adora Ben $10^{12}$ e o Bob Esponja ${ }^{13}$. Verônica é uma adolescente branca, com sardinhas no rosto e cabelo preto e cacheado. Verônica gostava de falar com o namorado e com amigos pelo Whatsapp ${ }^{14}$ e jogar no celular. Também adorava sair pra brincar

12 Ben 10 é um personagem de um desenho animado que usa seu relógio para se transformar em criaturas alienígenas e derrotar outros alienígenas.

13 Bob Esponja Calça Quadrada é um personagem de desenho animado. Ele vive no fundo do mar, seu melhor amigo é uma estrela do mar que se chama Patrick.

14 Whatsapp é um aplicativo de aparelhos celulares usado para enviar mensagens por internet. 
de queimada e pique-cola no campinho do Canaã.

A casa de Dona Rita tem dois quartos. O quarto de Dona Rita tem uma televisão, um armário e uma cama de casal, onde ela dorme com Caetano. O outro quarto é de Verônica e tem uma cama de solteiro e uma cômoda. Nos dias que dormi lá, fiquei no quarto de Verônica e a adolescente dormiu com a mãe e com o irmão mais novo no outro quarto. Além dos dois quartos, a casa tem uma sala junto com a cozinha onde ficam um sofá, uma televisão, uma geladeira e o fogão. $\mathrm{Na}$ área externa da casa, ainda dentro da cerca, ficam as casinhas dos cachorros Fiona e Scooby, a caixa d'água e a horta. Dona Rita planta milho, abóbora e feijão. O banheiro também fica na área externa. Uma pequena construção de madeira, com uns tapumes de madeirite no chão para a água escorrer para o lado de fora durante o banho. Diferente da maioria das outras casas, o banheiro da casa de Dona Rita tem um vaso sanitário.

No dia 9 de setembro, fui direto para a casa de Dona Rita depois que cheguei no Canaã. Dona Rita e Caetano estavam sentados do lado de fora da casa. Caetano desenhava em um papel. Verônica tinha saído para a colheita do morango fora do acampamento. Faltava energia nas casas do Canaã aquele dia. Cumprimentei Dona Rita e Caetano e ela me convidou a sentar.

Caetano: To desenhando um tubarão!

Dona Rita: Será que essa energia volta? Como o povo vai assistir os Dez Mandamentos hoje?

Gustavo: Tem alguém arrumando?

Dona Rita. Acho que o Alberto tá lá vendo

Caetano: Agora o tubarão tá comendo o amigo tubarão dele.

Nas noites no acampamento, a novela da Record Dez Mandamentos fazia muito sucesso. A novela conta a história do êxodo dos hebreus do Egito, liderados por Moisés. Entre agosto e outubro, nos meses que estive mais frequentemente no Canaã, Moisés lançou as pragas de Deus contra o Egito: rãs, gafanhotos, piolhos, moscas, chuva de granizo etc.. A cada semana, a novela trazia uma das pragas. A novela empolgou os moradores, que acompanhavam, comentavam e reliam trechos da bíblia com muitas expectativas sobre o futuro da novela.

Dona Rita: Só ameaça chover que a luz acaba. Você gosta de chuva, Gustavo?

Gustavo: Tá muito seco. To sentindo falta de chuva.

Dona Rita: Eu tenho medo de chuva de vento.

Gustavo: Chuva de vento?

Dona Rita: É. Quando venta muito e tem muito trovão. Começo desse ano ventou tanto que eu achei 
que ia levar o barraco. Caetano morreu de medo. Ficou dizendo "Mainha! Vamos pra escola! Lá a chuva não derruba!” - Dona Rita riu.

Caetano: Mainha, me dá mais uma folha?

Dona Rita: Dá uma folha pra ele, Gustavo? - Tirei uma folha do caderno de campo e entreguei para Caetano.

Gustavo: Vou dar uma passada lá na Rosa agora.

Dona Rita: Você trouxe as coisas de dormir?

Gustavo: Trouxe.

Dona Rita: Então até daqui a pouco.

Gustavo: Tá bom. Até mais!

Saí da casa de Dona Rita e fui para a casa de Rosa. Rosa é outra mãe que deu contribuições importantes para esta dissertação. Ela é uma mulher negra, franzina e tem por volta de seus 35 anos. Assim como Dona Rita, Rosa fala pouco nas reuniões. Ela está aprendendo a ler na escola do Rodeador no período noturno (Tornarei a falar da escola no capítulo III). Rosa é mãe de André (14 anos), Kethlen (11 anos) e Felipe (8 anos). A casa de Rosa fica em frente à plenária. A primeira vez que fui lá, Rosa me mostrou com orgulho o galinheiro que André e Kethlen fizeram do lado de fora. Naquele dia, quando cheguei, uma menina que ainda não conhecia estava na cozinha sentada, enquanto Rosa cozinhava.

Rosa: Senta um pouquinho. Toma um café.

Gustavo: Obrigado. É sua filha também?

Rosa: Não. Essa é minha amiguinha, né Lorrane? A conheci com o pai hoje no ônibus. Ela mora em uma chácara aqui do lado.

Gustavo: Oi Lorrane.

Rosa: Come mais um pouquinho.

Lorrane: Quero mais não. Acho que meu pai já tá chegando. Estou cheia de dever hoje.

Rosa: Vai assistir Dez Mandamentos não?

Gustavo: Você gosta dessa novela também?

Rosa: O que? Todo mundo aqui tá assistindo. Hoje tem mais uma praga. Acho que vão ser os sapos. Aquela novela é boa. O povo é igual aos Sem-Terra, sabia? Estavam atrás das terras deles também. A Terra Prometida. Tá na bíblia. A diferença é que naquela época Deus dava autoridade pra aqueles homens matar. Se hoje fosse "olho por olho, dente por dente".... Aí você ia ver o que era praga. 
A religiosidade cristã é muito presente no dia-a-dia do Canaã. Antes de todas as assembleias, reza-se o Pai-nosso. Eliana e Rosa são evangélicas. Dona Rita e Laura são católicas. O nome do acampamento - Canaã - se refere à terra prometida por Deus aos hebreus, de acordo com o Velho Testamento. No grupo do Whatsapp do acampamento circulam cotidianamente mensagens bíblicas e religiosas, na maior parte das vezes enviadas por Eliana.

Canaã tem uma igreja. Ela fica na mesma trilha da plenária, da vendinha e da casa de Rosa. Como a plenária, a igreja é feita de eucaliptos. Foi construída pelo Pastor Matheus para ser a sede do seu ministério. Pastor Matheus era um militante que ocupava o Canaã desde 2011. Ele morreu em decorrência de um atropelamento durante uma ocupação de terra feita pelo MST. Agora, algumas acampadas lutavam para que para sua filha fosse garantida uma parcela que selasse a luta do pai falecido. Depois de sua morte, a igreja passou a ser usada para reuniões menores. Também foi lá onde projetei os filmes para as crianças.

\section{Caminhão-Pipa}

Nas quartas-feiras pela manhã, a expectativa era grande pela chegada do caminhão-pipa no acampamento. Ele chegava por volta das dez horas da manhã e abastecia as caixas d'água espalhadas pelo acampamento. A frequência da vinda do caminhão-pipa era semanal na maioria das vezes. Mesmo que raramente, em algumas semanas o caminhão-pipa não vinha e a falta d'água eventual era gerenciada. As famílias entravam em um racionamento até a outra semana: pedindo para a vizinha, lavando menos roupa ou usando menos água no banho. As moradoras do Canaã me explicaram que os poços cavados só dariam água quando os eucaliptos próximos fossem retirados. Como as casas do acampamento ficavam na região em que os eucaliptos ainda não tinham sido cortados, os moradores dependiam da chegada semanal do caminhão-pipa.

Dona Rita estava do lado de fora de casa, lavando a roupa. Ela ouviu o som do caminhão e me chamou para buscar a água. Colocamos quatro galões vazios no carrinho de mão e fomos, Dona Rita, Caetano e eu para a caixa d'água. O ponto onde Dona Rita busca água é em frente à casa de Alberto, entre a igreja e o campinho onde as crianças jogam futebol e queimada. Existem ainda outras cinco caixas d'águas espalhadas pelo acampamento. Rosa já estava lá com seus três filhos. Alberto também estava a postos com seus galões. Um funcionário do caminhão-pipa desceu do carro, desenrolou a mangueira e mirou para a caixa. Um forte jato saiu da mangueira e foi aos poucos enchendo o recipiente. Caetano e Felipe seguraram os funis para suas mães. Dona Rita, Alberto, Rosa e André - filho mais velho de Rosa - e eu começamos a encher os galões com ajuda 
de cuias e funis.

Dona Rita: E você, Alberto? Acha que a direção tem que lutar por todo mundo que foi contemplado?

Alberto: Não. Por esse povo que nem dá as caras aqui?

Rosa: Eu gostei de ver Eliana falando na reunião. Luta é criar os filhos aqui dentro. É carregar água pra casa.

Dona Rita: E tinha tanta gente que morava aqui mesmo e que ficou de fora, lembra? Cecília, Eva, Ruan...

O filho mais novo de Rosa, Felipe, pegou um galho seco no chão. O cachorro de Alberto logo se aproximou do menino. Felipe balançou o galho de um lado para o outro e o cachorro começou a ficar animado. Em um movimento brusco, o cachorro abocanhou o galho. Felipe deu risada. O menino e o cão usaram o galho como cabo de guerra. Brincaram um pouco assim até que o cachorro finalmente largou o galho. A brincadeira voltou a se repetir com o cachorro tentando abocanhar novamente o galho seco.

Alberto: E de quem é que você quer ser vizinha quando cair pras parcelas?

Dona Rita: Eu? Ah qualquer um.

Rosa: Qualquer um? De jeito nenhum. Imagina se eu moro do lado do Tião? Deus me livre morar do lado daquele homem. - Alberto e Dona Rita dão risada.

Alberto: Uai Rosa. O cara é tranquilo. - diz em tom jocoso. O cachorro se empolga com a brincadeira com o galho e solta um latido.

Rosa: Tranquilo? E brinca assim pra você ver se eu não vou querer ficar bem longe de você e desse cachorro barulhento. - Alberto e Dona Rita riem novamente. Dessa vez não me contive na risada.

O momento de buscar água que chega com o caminhão-pipa é também um tempo de reatualizar as relações de vizinhança, de amizade. O tom de brincadeira entre Rosa e Alberto é de quem estabelece uma relação diferenciada. Rosa não brincaria da mesma forma com Tião, por exemplo, que ela diz explicitamente ser um desafeto. A ocupação da porção de terra em meio a eucaliptos cria relações de naturezas múltiplas. $\mathrm{O}$ vizinho pode ser alguém com quem se fofoca, se brinca, se ajuda. Pode também ser alguém que se xinga pelas costas, que não se quer próximo. As relações cultivadas na terra, desde o início do acampamento e estendendo-se a vida na terra parcelada, ocupam o território junto com o movimento. Nas palavras de Comerford (2003), estas aproximações entre vizinhos produzem territórios de parentesco: 
"Territórios aos quais certas famílias se vinculam no mapeamento social que se produz, nas conversas cotidianas e dentro das quais há uma liberdade, uma fluência de relações, uma familiaridade, que permite tolerar problemas de animais, água, divisas, bem como desatenções, brincadeiras, dívidas, coisas que em outras circunstâncias poderiam render consequências sérias" (COMERFORD, 2003: 40)

Perto da caixa d'água é um dos espaços em que este tipo de relação pode fluir. Entre Alberto, Dona Rita e Rosa, as fofocas e brincadeiras são feitas enquanto pega-se a água nas quartas-feiras de manhã. Em um clima de informalidade, Rosa consegue falar mal do cachorro de Alberto com uma liberdade e sem consequências maiores para a relação dos dois. Essas ocasiões diferem de encontros como os que se dão nas assembleias. As discussões na assembleia são sérias, assim como as consequências de suas deliberações. A assembleia não é um local para brincar, como bem sabem as crianças. Não é nela em que se deve fofocar sobre Tião ou se deve reclamar do cachorro de Alberto levianamente. Se Rosa chamasse o cachorro de Alberto de barulhento em tom sério na assembleia, seria encarado como um problema maior e as consequências para a relação entre Rosa e Alberto explicitariam um afastamento maior entre as vizinhas. Essa diferença entre o tom jocoso e o tom sério, que diferencia as conversas na caixa d'água e as discussões na assembleia, será retomada nos capítulos seguintes.

Quando enchemos dois galões inteiros com a água, voltei com eles para casa de Dona Rita empurrando o carrinho de mão, enquanto ela e Caetano enchiam os demais galões. Despejei os galões na caixa d'água da casa e voltei com o carrinho de mão e mais galões para serem preenchidos. No total, foi necessário repetir este percurso cinco vezes para conseguir encher a caixa d'água da casa de Dona Rita. Esperar o caminhão-pipa, carregar água, encher a caixa d'água... Eliana e Rosa disseram em diferentes ocasiões que este manejo da água faz parte da luta por uma parcela no Canaã. Após serem assentadas pela política de reforma agrária estas famílias não terão menos trabalho para usar a água. Até conseguirem um poço artesiano em suas parcelas, o ponto para a coleta de água provavelmente será ainda mais distante de suas casas. E, como em outros assentamentos, mesmo depois de cavarem um poço dentro da parcela, a água terá de ser carregada da mesma forma até suas novas casas.

Antes de qualquer uso cotidiano da água na casa, tínhamos que pegar um recipiente de tamanho adequado e que não gerasse desperdício. Escovar os dentes com um copo. Não mais que meio balde para dar descarga. Lavando as roupas se gastava mais água. Cerca de um terço da caixa d'água é usada para lavar as roupas da semana. O gasto de água elevado para lavar roupa justifica o 
desespero de Eliana quando seu filho caçula brinca na terra. Para tomar banho, esquenta-se uma lata com água no fogão a lenha e depois é necessário misturar a água quente com a água fria direto da caixa d'água até ter água morna. Um balde é suficiente para o banho. Este balde é carregado para o banheiro junto com uma cuia para despejar aos poucos a água do balde no corpo.

\section{A vida e a política entre eucaliptos}

Os percalços enfrentados para buscar a água e não deixá-la faltar relacionam-se com os outros aspectos da vida no Canaã apresentados neste capítulo. As agruras com a água estão imbricadas com a resistência da vida entre os eucaliptos e com a luta da família. Regar o milho, o imbú e a vinagreira despende de mais volume de água, pois as árvores puxam muita água. O poço artesiano não pode ser cavado perto dos eucaliptos. O manejo da água é feito por toda a família. As crianças também ajudam a pegar a água que o caminhão-pipa vem trazer. Toda a família corre os riscos entre os eucaliptos na luta pela terra. A família inteira deve primar pelo bom uso da água na escovação dos dentes, nos banhos, na brincadeira na terra, no uso da louça, etc...

A relação entre a água, a família, as plantas, as crianças, a novela, a terra e a luta do movimento explicita que a política no acampamento Canaã vai muito além das assembleias e reuniões no INCRA. Isso remonta o argumento de Paterniani (2013) sobre o imbricamento entre vida e política na ocupação Mauá (SP). “Amanhecer o dia de amanhã já é política” foi a frase dita pela liderança Nelson a autora que resumiu esta ideia de política enquanto estar-no-mundo. Muito mais do que uma atividade, a luta política é um modo de vida para os moradores da Mauá. Da mesma maneira, a luta da família, resistência entre eucaliptos, a novela Dez Mandamentos e manejo da água formam a vida no Canaã. Não é possível separar a luta por reforma agrária destas famílias dos aspectos que as afetam. Estando no acampamento e ocupando o Canaã, as moradoras vêm por inteiro.

Pretendo sustentar esta perspectiva na narrativa do cotidiano das crianças nos capítulos seguintes. As brincadeiras no acampamento também criam a ocupação no Canaã e fazem parte deste imbricamento entre vida e política. O próximo capítulo apresenta a ocupação que o movimento fez na Praça dos Buritis, em frente ao palácio do governador. Na frente do palácio do governador, as crianças brincaram, nadaram, marcharam e cantaram. Ocuparam a praça com tudo que envolve o seu estar-no-mundo.

A ideia de que os militantes são muito mais do que indivíduos expressa no jargão "a luta é da família" também é importante para esta dissertação. Neste capítulo, argumentei que a luta é um 
processo trans-individual, que perpassa as gerações e pode ser atribuída a qualquer familiar quando da conquista da terra, apesar de o INCRA operar com uma lógica de propriedade de individualiza os direitos de posse. No capítulo III, a convivência entre crianças e adultas também é entendida como uma relação que rompe com as barreiras do que é o indivíduo. Narrarei como a escola interrompe esta convivência e, assim como o INCRA, individualiza e atomiza crianças e adultas.

O processo de assentamento das famílias também não se encerra neste capítulo. Eles se arrastam até o último capítulo e permanecem sem um desfecho. A marcação na terra das parcelas ainda demoraria a ser concretizada. O acampamento Canaã teve que resistir entre eucaliptos por mais tempo. Retomarei as negociações entre INCRA e as militantes do MST no capítulo IV junto com uma discussão sobre o funcionamento do Estado e da burocracia. 


\section{CAPÍTULO II \\ CAFÉ-COM-LEITE, PIQUES E GIGANTES}

"Ser criança é ser feliz, pra ser feliz tem que brincar
pra brincar tem que sorrir, pra sorrir tem que lutar"

(Música cantada pelos Sem-Terrinha)

Uma ampla literatura discute, por diferentes perspectivas, a brincadeira, seja na Antropologia, na Psicologia do Desenvolvimento, na Sociologia da Infância e na Psicanálise. O saber acadêmico tratou os mais diferentes temas a partir da brincadeira: processos de aprendizagem, desenvolvimento da linguagem, socialização (VYGOTSKY, 1991), reprodução interpretativa do mundo adulto entre pares (CORSARO, 2002) etc.. As construções universalistas sobre sua função ou sobre o desenvolvimento cognitivo relacionado às brincadeiras são uma armadilha para quem quer levar a sério o que as crianças dizem. É curioso que uma ampla literatura enfoque no papel da brincadeira para tornar-se adulto e ao mesmo tempo reafirme a sua importância para uma cultura infantil.

Como quem tenta entender o que cresce no Canaã além dos eucaliptos, o desafio que me coloco neste capítulo é de entender a brincadeira em sua endogenia (MAFEJE, 1971, 1991), por ela mesma, ou seja, evitando o uso das categorias exógenas a essas brincadeiras e impondo-as para classificá-las e explicá-las. Durante a pesquisa, as brincadeiras nunca foram me apresentadas como socialização de papéis sociais ou como a melhor forma de aprender, como é frequentemente apontado por algumas das teorias. $\mathrm{O}$ caminho que as brincadeiras me levaram permitiram fazer outras perguntas: No que consiste o faz de conta? O que é guardar caixão? O que é café-com-leite? Qual a diferença entre correr no pique cola e correr na queimada? Com estas perguntas pouco usuais nos estudos sobre criança, refleti sobre conformação do espaço, do tempo e das regras.

\section{Caetano é difícil}

Eram quatro horas da manhã quando o barulho do foguete me acordou. Rapidamente me levantei no susto. O ônibus que levaria os acampados para frente do Palácio do Buriti sairia em trinta minutos. Entrando no nono mês do novo governo eleito em 2014, os dirigentes do MST no Distrito Federal disseram que quase não houve novas destinações de áreas para assentar famílias, o 
que paralisara a reforma agrária na região. Ônibus vindos de várias partes do Distrito Federal foram para a praça do Buriti para montar um acampamento que duraria algumas semanas. A estrutura do acampamento com cozinha, brinquedoteca, vendas e barracas para a militância dormir no meio do eixo monumental tinha como propósito pressionar o governo Rollemberg a dar mais celeridade às políticas de reforma agrária.

Não era somente o MST que entrava em embate com o governo naquele dia. Caetano não teve aula neste dia devido à paralisação de professores. O Sindicato dos Professores do Distrito Federal (SINPRO) chamava uma mobilização de professores para a mesma praça para onde estávamos nos deslocando ${ }^{15}$. Sob a insígnia "Calote não", naquela mesma manhã, os professores e outras categorias foram para a frente do Palácio contra a suspensão dos reajustes de seus salários, feitos pelo Governo de Brasília ${ }^{16}$. Com a paralisação dos professores para o dia de mobilização, Dona Rita e Caetano puderam ir à mobilização sem ter que faltar aula. Verônica não foi conosco porque a professora de matemática resolveu dar prova no dia de paralisação.

Troquei de roupa e saí do quarto. Ainda estava escuro e eu estava atordoado de sono quando Caetano diz "Mãe, a Fiona está com catapora". A cadela tinha várias pintas pretas no rosto. Dona Rita exclama: “Caetano! Você pintou o cachorro!”. O menino tinha pintado a cadela com o rímel da irmã, que ainda segurava em sua mão. Não conseguimos deixar de rir. "Caetano é difícil, Gustavo. Faz muita arte" disse Dona Rita sorrindo e preconizando as outras travessuras que o menino ainda faria naquele dia. Dona Rita colocou comida, algumas roupas e uns brinquedos de Caetano em uma mochila e saímos de casa. Cerca de vinte crianças, adultos e idosos do Canaã foram no ônibus para a ação do MST. Passamos ainda em outros dois acampamentos para buscar mais militantes. Eliana puxava com empolgação as músicas do movimento até chegar no Palácio. Caetano ficou quieto por quase todo o percurso. O menino só abriu a boca para cantar um verso de uma das músicas: "Essa luta é nossa. Essa luta é do povo.”

Chegamos à praça em nosso destino por volta das 6:30. A praça do Buriti fica no Eixo Monumental de Brasília e separa o Palácio do Buriti, que sedia o Governo de Brasília, da Câmara Legislativa e o Tribunal de Justiça do DF. Um espelho d'água divide a praça em duas áreas grandes. Na parte de cima do espelho d'água, muitos pés de manga. Dos dois lados, entre os monumentos e a praça, estão vias enormes, com cinco faixas cada. Os militantes logo se espalharam pela praça, entre as mangueiras, e armaram barracas. Alguns foram fazer a cozinha e outros foram jogar dominó.

15 Depois de algumas paralisações em setembro de 2015, os professores da rede pública do DF entraram em greve contra a suspensão do último reajuste prometido em 2013. A greve durou do dia 15 de outubro ao dia 12 de novembro.

16 No dia 18 de abril de 2015, o governador Rodrigo Rollemberg anunciou que o Governo do Distrito Federal (GDF) passaria a ser chamado de Governo de Brasília. 
Eliana pegou o triângulo e continuou cantando as músicas do movimento enquanto tocava. Caetano pega o relógio de brinquedo do Ben $10^{17}$ da mochila que sua mãe levou e começa a brincar:

Caetano: Esse relógio tá quebrado...

Gustavo: O meu tá funcionando. (apontando para um relógio invisível que estava no meu braço)

Caetano: Funciona nada!

Gustavo: Olha aqui! (faço um barulho com a boca)

Caetano pega novamente seu relógio e diz: Sou um gigante! E to pegando fogo! - ele roda pela praça um pouco, para na minha frente e diz - Você agora é um diamante! Pá!

Gustavo: Ahhhh!

Caetano: Agora eu sou um eucalipto e vou cair em você! (Caetano levanta seus braços e tomba para o lado em minha direção)

Caetano: Meu relógio agora não tá funcionando de novo...

Gustavo: Mas é de mentirinha, né Caetano?

Caetano: É de sonho.

Fians (2015) explora a categoria "de mentirinha", usada pelas crianças durante seu trabalho de campo para distinguir a brincadeira do que é sério. Seguindo o pensamento de Bateson (1972), o autor argumenta que a comunicação da brincadeira - de mentirinha - se baseia em um registro do como se fosse, em uma instável e parcial contraposição com o registro de como é, do que é sério. $\mathrm{Na}$ brincadeira com Caetano, a comunicação guarda similaridades com o registro da mentirinha descrito por Fians. O fato de falar "sou um gigante" não distingue Caetano de "ser um gigante" em certo nível. A brincadeira consiste em agir como se fosse um gigante, apontar o relógio para alguém como se o transformasse em diamante, correr como se estivesse sendo perseguido. Bateson (1972) apresenta muito bem esse caráter metacomunicativo da brincadeira, que de forma muito instável se diferencia da denotação: "Expandida, a menção 'Isso é uma brincadeira' é algo como: Estas ações em que nos engajamos agora não denotam o que elas denotariam ${ }^{18}$." (BATESON, 1972: 317).

Muito inspirado nestas reflexões, perguntei a Caetano se aquele faz de conta era de mentirinha. A resposta de Caetano associou a brincadeira ao sonho. Do mesmo modo que os sonhos, o limite da brincadeira é a barreira entre o que é falso e o que é verdadeiro. Sonhos e

17 Ben 10 é um personagem de um desenho animado que usa seu relógio para se transformar em criaturas alienígenas e derrotar outros alienígenas.

18 Tradução livre: Expanded, the statement "This is play" looks something like this: "These actions in which we now engage do not denote what those actions for which they stand would denote". 
brincadeiras não operam com esta dicotomia ${ }^{19}$. Qualquer pensamento referente a condição de sonhar ou questionamento da sua veracidade só ocorre quando estamos despertos ou em um momento próximo a acordar (BATESON, 1972).

Freud (1900) diz que os sonhos se diferenciam do pensamento lógico-formal. Os sonhos operam por imagens que são vividas enquanto realidade e enquanto experiência. Estamos falando de uma linguagem não denotativa, não representacional. Na leitura de $A$ Interpretação dos Sonhos de Tambiah: "Em outras palavras, o sonho faz as relações lógicas colapsarem, ou no mínimo ele não dispõe de nenhum meio para representar relações como as de "e se", "porque", "tais como", “isso ou aquilo" e relações de "causa", "conexão" e "contradição".” (TAMBIAH, 2013: 14)

Seguindo esse pensamento, ao levantar as mãos e tombar, o menino não está representando um eucalipto, e sim expressando com gestos, sons e palavras o que é ser um eucalipto e evocando os efeitos de seu derrubamento. Essa forma não-representacional de comunicação e de pensamento aproxima a brincadeira da ficção, da poesia, da música, e de outras artes, "que nada denotam mas 'muito mostram' e transmitem sentimento" (TAMBIAH, 2013: 28). A brincadeira surge a partir de um ato criativo, em que a percepção da realidade é simultânea a lembrança de sabores, cheiros, nomes, formas, animais e sentimentos. Esta simultaneidade entre percepção da realidade e a memória da criança distancia a brincadeira da dicotomia entre realidade e ficção, aproximando-a de outras atividades da mente.

A brincadeira de Caetano mistura os eucaliptos do Canaã, o relógio do Ben10 da TV e a lembrança de algum gigante, atualizando todos esses elementos no mesmo ambiente da praça em frente ao Palácio do Buriti. Essa fusão entre realidade e imaginação é convertida e atualizada em performance (HARTMANN, 2015) pelo menino. A brincadeira de Caetano é também feita com seu corpo. O menino corre em círculos para indicar que está pegando fogo. Ele ergue as mãos para fazer-se de eucalipto. Á medida que performatiza com seu corpo, sonha com uma história de gigantes, fogo e eucaliptos.

Já eram quase meio dia quando Dona Rita interrompeu a brincadeira e chamou Caetano. Militantes do movimento se dirigiam à pista do Eixo Monumental. No caminho para ocupar a via, Caetano vê o espelho d'água da praça:

Caetano: Mainha, posso entrar na água?

Dona Rita: Tá suja, Caetano.

19 Similarly, within dream or fantasy the dreamer does not operate with the concept "untrue". He operates with all sorts of statements but with a curious inability to achieve metastatements. He cannot, unless close to waking, dream a statement referring to (i.e. framing) his dream (BATESON, 1972:321) 


\section{Caetano: Ah não!}

Dona Rita: Tem jacaré aí. - Caetano olhou para a água procurando o jacaré do espelho d'água. O menino não disse mais nada e seguimos para a rua.

Do outro lado do espelho d'água, ainda na praça em frente ao Buriti, o carro de som do SINPRO puxava gritos de ordem contra o governo do Rollemberg. O MST ocupou uma via do Eixo Monumental em frente ao Palácio do Buriti e deu a volta na praça pela contramão dos carros, passando ao lado do carro de som dos professores. A militância contornou a praça e marchou no outro sentido do Eixo Monumental, em frente à Câmara Legislativa do Distrito Federal, ainda na contramão. A polícia acompanhou todo o trajeto. Kethlen, Lucas, Leonardo e outras crianças do Canaã também ocuparam a via. Eliana seguia puxando as músicas do movimento enquanto marchava. Mais tarde, Chico me falou que o movimento repetiria o mesmo trajeto nos dias posteriores até a polícia se acostumar. Assim poderiam ocupar algum órgão com a polícia desatenta.

Depois de contornarem a praça pela contramão da via, os integrantes do movimento voltaram para seus afazeres na praça. Caetano novamente quis entrar no espelho d'água. Dona Rita alertou: "E o jacaré, Caetano?”. O menino ignorou, ficou só de cueca e pulou na água. A mãe riu. "Caetano dá trabalho" disse ela para mim. Depois que Caetano pulou na água, não demorou muito e outras crianças entraram também. Uma menina e dois meninos de outros acampamentos pularam na água e brincaram de jogar água uns nos outros. Outra menina chega na beira do espelho d'água sem entrar:

Menino: Entra também!

Menina: Minha mãe não deixa...

Dona Rita, que antes estava reticente de seu filho entrar, diz: Entra um pouquinho.

A menina se anima e pula na água de roupa mesmo. As cinco crianças riem muito. Não passa muito tempo uma mulher bastante irritada vem andando e grita "Júlia". A menina que tinha entrado por último rapidamente sai da água. “Eu não tinha dito pra você não entrar aí?”. A menina não responde nada e volta com a mãe até as barracas entre as mangueiras.

Assim como nas atividades do MST na praça, as brincadeiras que acompanhei muitas vezes se depararam com este tipo de limite. As mães proíbem os filhos de irem a certos lugares ou de se engajarem em certas atividades. Apesar disso, como com qualquer limite, estas proibições são testadas e recorrentemente negociadas. Em minha monografia de graduação, discuti a forma criativa das crianças testarem os limites colocados pelo disciplinamento da escola. Tanto as crianças quanto 
professores e orientadores educacionais exercitavam a criatividade em uma negociação constante dos limites das crianças na escola (BELISARIO, 2013).

A negociação desses limites muitas vezes se dá a partir de uma ontologia desobediente, que insiste em ultrapassar os limites. Dona Rita não deixou Caetano entrar no espelho d'água e o menino entrou assim mesmo. A mãe de Júlia igualmente não a deixou entrar na água. Incentivada pela própria Dona Rita, a menina também entrou apesar da proibição, enfrentando consequências diferentes das de Caetano. A desobediência de Caetano "dá trabalho", como Dona Rita disse. Mesmo assim, a mãe parece se divertir em alguns momentos que o filho se torna "difícil", como quando ele pintou a cadela com rímel. A postura de Dona Rita, que muitas vezes me parecia um incentivo à desobediência de suas próprias ordens, me chamou atenção. Esta postura de incentivar que suas ordens não sejam levadas a sério lembra o que Wagner (2009) descreve em relação aos Daribi, em que tornar-se adulto é aprender a não levar tão a sério as convenções e a vergonha de não segui-las: "Isso significa aprender, sob as devidas circunstâncias, a não levar a vergonha nem um pouco a sério, a ser capaz de usar a vergonha (fazendo-se vergonhoso ou elicitando-o nos outros) para fins morais. Significa aprender a pecar, pois sem pecado não há salvação.” (WAGNER, 2009: 234)

É também movido pela desobediência que o MST ocupa a praça do Buriti, as vias e os órgãos públicos. A polícia tenta o tempo todo limitar a ação do movimento. Mesmo assim, o movimento possui técnicas para enganar e surpreender a polícia e ultrapassar os limites da contenção. Como Chico disse, a repetição do mesmo trajeto todos os dias tinha como propósito pegar a polícia desprevenida, da mesma forma como nas brincadeiras existe a fita, quando um jogador faz que vai para um lado e vai para o outro, para enganar o adversário.

No capítulo I, remontando o argumento de Paterniani (2013), defendi que política e vida são indistinguíveis no acampamento Canaã. Da mesma forma, é possível dizer que vida e política estão tão imbricadas para militantes do MST que a ação política na praça é formada por toda complexidade que compõe a vida. Na ocupação da praça do Buriti militantes cantam músicas, marcham, jogam dominó, nadam com jacarés de faz de conta, brincam de Ben 10, cozinham e desobedecem mães e policiais. A brincadeira, como parte da vida, se mistura com todo este movimento pulsante fazendo parte da politização do espaço da praça, que dá trabalho para os policiais, os motoristas de carro e para o governador.

\section{Tô de licença}


A criatividade e as mensagens metacomunicativas também fizeram parte de brincadeiras coletivas. No trecho a seguir, as orientações e limites colocados pelas mães conformam os tempos e espaços do pique-cola americano. A passagem começa com Cleonice e Victor indo nas casas de outras crianças do acampamento para chamá-las para brincar. Algumas vezes, uma negociação com as mães precede sair de casa.

Era domingo, seis de setembro, quando fui à casa de Laura. Eu já tinha almoçado, mas não neguei a cachaça que João, seu marido, me ofereceu. Além de mim e do casal, Tião e Alberto estavam na parte externa do barraco almoçando, tomando cachaça e vendo a tarde passar. . Os filhos de Laura e João estavam dentro de casa assistindo a um desenho animado na televisão. Cleonice, de onze anos, e Victor, de seis anos, estavam ansiosos para sair para brincar. A mãe lhes disse para esperar o sol baixar. Por volta das 15 horas, Cleonice e Victor saem do quarto e perguntam para a mãe:

Cleonice: Agora já pode mãe?

Laura: Pode.

Cleonice: Vamos, Gustavo! (bastante empolgada)

Levanto-me da cadeira, Cleonice e Victor pegam as suas bicicletas, passamos pelo cachorro e pelo galinheiro até sair do barraco. A poeira subia bastante no passar das bicicletas, típico do tempo seco do início de setembro no Distrito Federal. Sobre a terra vermelha e entre os eucaliptos e barracos, Cleonice e Victor foram chamar as outras crianças. Os dois irmãos param em frente a um dos barracos e Cleonice grita com certo ritmo:

Cleonice: Verôôôônica! Verônicáááááá! Verôôôôôônica!

Verônica: Que foi?

Cleonice: Vamos brincar de Pique Cola!

Verônica: Onde?

Cleonice: Pode ser no campinho da sua casa.

Verônica: Tá bom. Chama o resto.

Cleonice sai com sua bicicleta novamente entre os eucaliptos. Chegamos na casa de Eliana, mãe de quatro filhos: Lorena (14 anos), Lucas (12 anos), Leonardo (9 anos) e Luisa (5 anos). Cleonice comenta que Eliana raramente deixa que os filhos saiam para brincar. A menina torna a grita o nome da filha mais velha: 
Cleonice: Loreeeeeeena! Lorenáááá!

Lorena: Que foi?

Cleonice: Vamos brincar de Pique-Cola?

Lorena: Tô lavando a louça. (Eliana sai do barraco com as outras crianças e carregando uma bíblia)

Eliana: Que foi Cleonice?

Cleonice: Deixa os meninos brincar com a gente.

Eliana: Cê não tá lavando a louça Lorena?

Lorena: To acabando já mãe. Deixa!

Eliana: Eu num gosto quando escurece e vocês ainda não voltaram...

Gustavo: Eu trago eles aqui quando estiver escurecendo.

Depois de alguma insistência, Eliana deixou que Lorena, Lucas e Leonardo fossem brincar conosco. Entretanto, a caçula Luisa não ganhou a permissão de ir com seus irmãos. Tinha tomado banho e sua mãe não queria que a menina se sujasse de terra. Frustrada de não poder ir, Luisa ficou aos prantos no barraco enquanto seus irmãos foram jogar pique cola americano com as outras crianças. Mais de uma vez enquanto estive no Canaã, as brincadeiras coletivas no acampamento foram precedidas deste momento de chamar as outras participantes. Nem todas as crianças eram visitadas para que participassem da brincadeira. Algumas eram em uns dias e não eram no outro. Tinham aquelas que as outras sabiam que não estavam no acampamento naquela hora. Outras não eram chamadas por alguma desavença. E em algumas casas, as crianças tinham que negociar com as mães os termos para poderem sair. Algumas mães eram reconhecidas por serem mais difíceis para negociar, como é o caso de Eliana.

A brincadeira propriamente não começou. Porém, a medida que as crianças vão sendo chamadas ela já começa a ganhar alguns contornos: quem participa, quando ela pode começar, até que horas ela vai, onde vai ser, etc. Depois do sol baixar, antes de escurecer, antes de banhar, após terminar as tarefas domésticas indicam os marcos temporais do início e do término da brincadeira. $\mathrm{O}$ espaço da brincadeira também começa a ganhar forma nesse momento de chamamento e negociação com as mães. Se as crianças vão brincar no campinho perto da casa de Verônica e Caetano ou no campão fora do acampamento, longe o suficiente para que algumas mães não deixem, são todas possibilidades cogitadas quando se chama as outras crianças para brincar. $\mathrm{O}$ convite feito por Cleonice, "vamos brincar de Pique Cola?", anuncia uma atividade com uma qualidade singular de perturbar as outras feitas no cotidiano.

Alguns minutos depois, sete crianças do Canaã se reúnem no campinho do acampamento. 
Discutem por um tempo quem seria o "pego" da brincadeira. Decidem que o pego seria a Lorena. Em poucos segundos nós começamos a correr. Lorena corre atrás de mim. Corri o mais rápido que consegui. Virei em um dos barracos perto do campinho. O cansaço logo denunciou a falta de costume de correr. Apoiei-me em um eucalipto e Lorena toca em mim dizendo "tá pego". Fico parado por estar "colado" um tempo com Lorena em pé ao meu lado. "Não vale guardar caixão!" grita Lucas de longe. A menina então corre atrás de Verônica e Lucas chega correndo e me "descola". Verônica e Lorena correram em direção à casa de Alberto. O cachorro da casa late bem alto a medida que as crianças se aproximam e Verônica desvia para outro lado. Corri em direção à igreja do falecido pastor Marcos e Verônica me diz:

Verônica: A gente não corre praí não.

Gustavo: Não?

Verônica: Não. A igreja é mal assombrada.

A medida que a brincadeira acontece, ela vai conformando um certo lugar, um certo espaço. "A gente não corre praí” apresenta a forma como esse espaço é conformado. A construção do espaço aqui se difere muito do esquadrinhamento territorial das parcelas feito pelo INCRA. A divisão "não correr prá'” e "correr praí" não apontam um espaço determinado por um sistema métrico dimensionalmente limitado. Mesmo não seguindo uma delimitação espacial métrica, a brincadeira das crianças também se orienta por limites. Correndo em determinada direção, as crianças esbarram em casas, eucaliptos, cachorros e no "pego" da brincadeira. Os latidos, a casa mal assombrada, os galhos de eucalipto são matérias de expressão que produzem limites no espaço em que as crianças correm.

Em um curso sobre Spinoza em 1981, Deleuze propõe a distinção entre duas formas de limite: o limite contorno e o limite tensão, que é semelhante a diferenciação entre espaço estriado e espaço liso O limite contorno é aquele que produz uma contenção externa e dimensional daquilo que é interno. No limite contorno, a ação do conteúdo é menos relevante do que a forma gerada pelos limites. Contrariamente, o limite tensão se define justamente pela potência do corpo. Assim, o limite do latido do cachorro vai até onde ele age, o limite do pego não é definido por uma área inteira, mas até onde vai a potência dele. A brincadeira no pique-cola americano, assim, possui limites tensão que orientam o espaço e nenhum limite contorno.

Alguns desses limites do espaço da brincadeira são produzidos no frame "Isso é uma brincadeira" descrito por Bateson. É o caso de quando Lucas pede para que Lorena não "guarde caixão". "Guardar caixão" é quando o "pego" da brincadeira fica próximo ao "colado" para impedir 
que as demais pessoas a "descolem”. Isso produz uma estabilidade na brincadeira, uma vez que a "pega" não corre atrás de mais ninguém e as outras pessoas não se arriscam para "descolar" o "colado". Por paralisar os vetores do Pique Cola, Lucas evoca a uma regra que ninguém tinha mencionado até então: Não vale guardar caixão. A evocação dessa regra torna a desestabilizar o espaço da brincadeira e recria o movimento dos vetores. O colado passa a ser um limite tensão para o pego.

O espaço do Pique Cola Americano se transforma criativamente de acordo com as sucessivas mudanças de direções das crianças. Estes movimentos estão sempre atentos às marcas que expressam diferenças no espaço. Estas marcas podem ser de brincadeira (guardar caixão) ou produto de outras ficções (latir do cachorro, mal assombro, os eucaliptos).

Lorena estava quase pegando Cleonice quando a menina exclama:

Cleonice: Tô de licença!

Lorena: Não vale.

Lucas: É Lorena. Não pode pedir licença só pra não ser pega.

“To de licença" é uma expressão que suspende uma pessoa da brincadeira por um tempo determinado, de forma que ela, no caso do Pique Cola Americano, não pode ser colada. De maneira geral, a licença é pedida para que se possa beber água, ir ao banheiro ou mesmo descansar por um tempo. Obviamente, a licença somente suspende a brincadeira, não suspende latido dos cachorros ou o mal assombro da igreja. Porém, Cleonice pediu licença para não ser queimada, usando-a para interromper o fluxo correr - ser colado - ser descolado. Lorena e Lucas rapidamente disseram que esse uso não vale.

As regras da brincadeira aqui novamente são evocadas ao longo do jogo, não tendo sido ditas ou combinadas antes. "Não vale guardar caixão", "não vale (pedir licença só pra não ser pega)" foram frases ditas ao longo do processo de invenção iniciado com a brincadeira. Não existiu um momento contratualista de elaboração das regras da brincadeira. As regras são evocadas de acordo com cada situação com o intuito de manter o fluxo da brincadeira. Seriam regras-tensão no lugar de regras-contorno?

\section{Dominó e a história social do brinquedo}

Dona Rita não ficou o tempo todo na praça por causa das aulas de Caetano. A paralisação de professores ainda não tinha culminado na greve, que só se iniciaria no dia 15 de outubro. No dia 
seguinte da ocupação da praça, Dona Rita voltou comigo e com Caetano para o Canaã. Quando a ocupação completou uma semana, no dia 30 de setembro, quinta-feira, Dona Rita voltou para a frente do Palácio do Buriti. Dessa vez, a militante foi preparada para ficar uns dias a mais, inclusive tendo trazido sua barraca, e estava acompanhada também de Verônica. A adolescente falou para sua mãe sobre uma nova paralisação de professores para aquela semana, o que Dona Rita descobriu posteriormente ter sido uma invenção de Verônica para também poder ir para a praça.

Saímos do acampamento Canaã às 7 horas da manhã. Na rodovia, esperando o ônibus para ir para o trabalho, encontramos Alberto e Rosa. O ônibus chegou cheio. Pagamos a nova tarifa de quatro reais. Caetano passou por cima da catraca. Descemos na parada em Taguatinga, nos despedimos de Alberto e Rosa, e pegamos o segundo ônibus, dessa vez direto para o Plano Piloto. Novamente, a tarifa era de quatro reais, menos para Caetano que pulou a catraca de novo. O segundo ônibus estava mais cheio que o primeiro. Pegamos o intenso trânsito da Estrutural. Chegamos na Praça do Buriti às 9 horas da manhã.

Quando chegamos, o MST já estava ocupando a Terracap ${ }^{20}$, que fica atrás do Palácio do Buriti. Além do MST, outros movimentos de luta pela terra no DF participaram, como a Frente Nacional de Luta (FNL) e o Movimento Brasileiro dos Sem-Terra (MBST). O objetivo da ocupação era denunciar a grilagem de terras feitas no DF com anuência da Terracap e exigir que a empresa pública agilize o repasse de terras para a reforma agrária. Não passamos muito tempo lá. Alguns minutos depois, o movimento organizou a sua saída do prédio da Terracap para voltar para a Praça do Buriti. Fizemos três filas com mulheres, homens e crianças e cantamos as músicas do movimento. Na fila, Caetano puxava um pedaço de isopor amarrado por um pedaço de barbante. Com a força do barbante, o menino fazia curvas com o isopor e, de repente, corria um trecho para ver a aceleração de seu novo brinquedo, saindo por alguns minutos da fila de militantes. O isopor torna-se um carro nas mãos de Caetano.

Para Vygotsky, a brincadeira produz sempre uma situação imaginária das quais é possível observar regras. Uma brincadeira se aproxima da situação real, por exemplo de dirigir um carro, e é orientada pela forma como os adultos se comportam. Mesmo que de forma oculta, esta brincadeira carregaria regras relacionadas a dirigir um carro:

"Pode-se ainda ir além, e propor que não existe brinquedo sem regras. A situação imaginária de qualquer forma de brinquedo já contém regras de comportamento, embora possa não ser um jogo com regras formais estabelecidas a priori. A criança imagina-se como mãe e a boneca como criança

$20<$ http://www.correiobraziliense.com.br/app/noticia/cidades/2015/09/30/interna_cidadesdf,500632/predio-daterracap-e-invadido-por-sem-teto-grupo-critica-atuacao-do-o.shtml $>$ 
e, dessa forma, deve obedecer as regras do comportamento maternal.” (VYGOSTKY, 1991: 63)

Nesta perspectiva, as brincadeiras são entendidas como um meio para o desenvolvimento do pensamento abstrato e da introjeção das regras de comportamento social. A brincadeira faz parte da socialização, da trajetória que leva uma criança a ser adulto. Nesta dissertação, adoto uma perspectiva diferente da de Vygostky. A infinidade de formas de brincar com um pedaço de isopor, como Caetano nos mostra, não prescinde de nenhuma obediência às regras e nenhum caminho único em direção ao pensamento abstrato e ao mundo convencional. As muitas maneiras de brincar envolvem muitas maneiras de lidar com as convenções, inclusive da possibilidade de brincar de subvertê-las. Essa perspectiva de que as brincadeiras podem submeter às convenções a ela, e não só reproduzi-las, se aproxima da de Benjamin (2009). O autor defende uma desvinculação da imaginação de quem brinca e o conteúdo dos brinquedos:

“ Hoje talvez se possa esperar uma superação efetiva daquele equívoco básico que acreditava ser a brincadeira da criança determinada pelo conteúdo imaginário do brinquedo, quando na verdade dáse o contrário. A criança quer puxar alguma coisa e torna-se cavalo, quer brincar com areia e tornase padeiro, quer esconder-se e torna-se bandido ou guarda." (BENJAMIN, 2009: 93)

A situação imaginária, portanto, não está submetida às regras. $\mathrm{O}$ mundo e as regras estão sujeitos a se transformar frente a imaginação de quem brinca. Benjamin diz que os "instrumentos de brincar" (bonecas, carrinhos, etc) afastam a criança da "brincadeira viva" e da imaginação, pois tentam imitar aspectos do mundo adulto. Para este autor, as convenções, as regras e a estética do mundo adulto fazem parte do jogo, que ele diferencia da brincadeira por esta enfatizar o movimento, a imaginação. Benjamin também entende como parte do jogo os objetos feitos para serem brinquedos, e que muitas vezes são feitos para parecerem de verdade - bebês de verdade, carros de verdade. No lugar de focar uma socialização para o mundo adulto por meio da brincadeira (VYGOSTKY, 1991), as regras podem ser entendidas como um constrangimento a continuidade da brincadeira. Ou, nas palavras de Wagner (2009), as convenções podem ser "responsabilidades" intrusivas.

Minha experiência em campo foi de que as fronteiras entre jogo e brincadeira eram muito fluidas. As brincadeiras mais livres, de faz de conta por exemplo, rapidamente podiam ser levadas muito a sério e recorrer a regras. Os jogos com regras rígidas vez ou outra levavam a felxibilização dessas regras em favor da situação imaginária. Mesmo sendo escorregadia, essa distinção entre jogo e brincadeira pode ser interessante para pensar uma diferença de postura em relação às regras, por 
exemplo, na exclusão de Caetano do jogo de dominó da praça em frente ao Palácio do Buriti.

Assim que voltamos para a praça, Cleonice me chama para jogarmos dominó com outros dois homens que estavam embaixo das mangueiras. Aceitei o convite e Caetano também foi junto. Cada jogador começa com sete pedras. Cada uma delas carrega dois números de zero a seis. O jogador só pode baixar a pedra quando ela tem um número que corresponda ao da pedra na mesa. A dupla pontua quando um dos jogadores desce todas as pedras de sua mão. A dupla vence quando completa quatro pontos. Arrumamos os banquinhos de plástico e uma caixa de papelão para ser a mesa. Caetano começou a mexer nas pedras do dominó e um dos homens disse que ele não poderia jogar, pois não sabe e só atrapalharia. Caetano voltou para a barraca chorando. Cleonice (11 anos) foi minha dupla contra os dois homens.

Ariès (1981) escreve que a exclusividade de brinquedos e brincadeiras para crianças é recente, assim como o próprio sentimento moderno de infância. As arqueólogas dizem ter dificuldade de distinguir bonecas e artefatos em miniatura feitos para crianças e de uso de adultos da idade média. Para o autor, o divertimento dos adultos era o mesmo das crianças. A separação entre jogos de crianças e de adultos só vem a ocorrer ao longo dos séculos XVII e XVIII, quando um movimento de moralização da infância convenciona que os jogos de azar como o baralho, xadrez e dados, até então jogados comumente pelas crianças, passam a não mais ser adequados a estas. Segue-se a isso, uma sucessão de regras e de punições elaboradas pelos padres das escolas para convencionar que jogos eram adequados.

Quando o homem diz a Caetano que ele não pode jogar, o homem não evocou um impeditivo moral, e sim um impeditivo cognitivo. Caetano não só é incapaz de jogar dominó como é incapaz de aprender a jogar dominó, capacidade essa que Cleonice, alguns anos mais velha, possui. Partindo dessa postura, as regras estipulam como é o jogo de dominó e qualquer forma de manusear as pedras como se estivesse em outra situação imaginária é suficiente para que o jogo não aconteça. Saber jogar dominó implica em saber os limites que as regras colocam.

A distinção de Benjamin entre brincadeira e jogo é bastante adequada para pensar a diferença entre a relação de Caetano com o isopor puxado como carrinho e do adulto com o dominó jogado na praça. No dominó jogado na praça, o jogo é determinado pelo conteúdo imaginário do próprio instrumento e de suas regras. Enquanto com o menino e o isopor, o conteúdo do brinquedo é definido pela imaginação de quem brinca. Evidentemente, essa distinção não é somente uma propriedade dos objetos de brincar/jogar. É possível brincar com pedras de dominó de infinitas maneiras, assim como é possível inventar um jogo que envolva um pedaço de isopor.

Benjamin associa a brincadeira à criança assim como o jogo ao adulto. Não deixa de existir certa referência à idade quando Caetano é expulso por não saber jogar e Cleonice, poucos anos mais 
velha, pode jogar. Porém, essa distinção etária entre criança e adulto se mostrou mais complexa durante a pesquisa. Por exemplo, na brincadeira, mesmo sendo associada comumente ao mundo da infância, essa distinção entre criança e adulto não se colocou, como explorarei na seção seguinte.

\section{Eles são café-com-leite}

No último domingo de setembro, Verônica me chamou para jogar queimada no campinho do Canaã. Além de mim, Verônica chamou André, Kethlen e Felipe na casa de Rosa e depois chamou Cleonice e Victor. A próxima casa no caminho do campinho era a de dona Eliana. Quando vi que estávamos passando da casa de Eliana sem chamar os filhos dela para brincar, perguntei:

Gustavo: Vamos passar na casa da Lorena agora?

Verônica: Ah não. O Lucas e o Leonardo não sabem brincar de queimada.

Gustavo: Como assim não sabem brincar?

Verônica: Eles jogam a bola muito forte.

O saber-brincar neste caso da queimada é diferente do saber-jogar do dominó. O saber-jogar dominó envolve o pleno conhecimento das regras. O saber-brincar na queimada nada tem a ver com saber ou não as regras. Lorena não diz que Lucas e Leonardo não sabem brincar por não saberem as regras do jogo-queimada, mas por jogarem a bola muito forte, ou seja, por levarem a brincadeira a sério demais ao ponto de machucarem outras pessoas. Esquecem que "isso é uma brincadeira” e que mais importante que ganhar é não sair ninguém de lá machucado.

Mesmo com essa ressalva de Verônica, acabamos passando pela casa dos filhos de Eliana. Lucas e Leonardo estavam brincando "de sério". Um olhava para o outro fixamente tentando segurar o riso. Lucas logo perdeu a postura e começou a rir. Leonardo disse feliz "ganhei”. Eles recomeçaram a se olhar esperando um o riso do outro. Dessa vez foi Leonardo que olhou para baixo e soltou um pequeno riso. É importante salientar que "brincar de sério" é bem diferente de "levar a sério uma brincadeira". O brincar de sério opera pelo frame "estamos brincando", os meninos estão sérios, mas é de brincadeira. É diferente do não saber-brincar por levar a sério demais a brincadeira, pois esse é um momento de suspensão do frame "estamos brincando". A diferença entre levar a sério a brincadeira, brincar de sério e brincar com coisa séria será retomada no capítulo IV.

Quando a brincadeira cessou, Verônica disse para que os meninos chamassem Lorena para jogar queimada. Os meninos gritaram "Lorêêêena!" e a menina saiu de casa. Verônica a convidou 
para jogar queimada. Os três irmãos nos acompanharam até o campinho. Chegando no campinho, Verônica se vira para Lorena e diz:

Verônica: Podemos chamar o Alberto também né?

Lorena: É mesmo! (As duas se dirigem a um barraco próximo ao campinho e gritam:)

Verônica e Lorena: Albeeeerto! Albertooooo!

Alberto: Que foi?

Verônica: Vem jogar queimada com a gente!

Alberto: Agora?

Lorena: É

Alberto: To indo já. Espera um pouquinho.

As meninas foram para o campo tirar time. Desta vez, um adulto estava sendo chamado para jogar queimada junto com as crianças. Alberto de fato apareceu depois na brincadeira e jogou conosco, da mesma forma que Cleonice jogou dominó na praça e que Dona Rita brincou que tinha um jacaré no espelho d'água em frente ao Palácio do Buriti.

A brincadeira começa com Verônica e Lucas tirando time. Os dois tiram par ou ímpar. Lucas ganha e me escolhe como jogador. Os dois alternam-se na escolha dos jogadores até que somente Caetano e Victor, ambos de cinco anos, sobrassem. Verônica diz que eles podem ser café-com-leite e divide um para cada time. Cleonice pergunta “eles podem queimar e ser queimado?" e Verônica responde que sim. "Só não pode jogar a bola forte neles". Logo após tirarem os times, Alberto chega e integra o time de Verônica.

Depois de tirar os times, Cleonice marca com um chinelo o meio do campo, dá dez passos grande para uma das direções e faz outra marcação, retorna para o meio do campo e dá outros dez passos grandes na outra direção. Assim, marca os campos dos dois times e a área para onde vão as pessoas queimadas. Começamos a brincadeira. A bola começou com o nosso time (Eu, Lucas, Lorena, Victor, Kethlen e Felipe). Lucas foi o primeiro a jogar a bola. O menino jogou com força em direção a Cleonice, que escapou por um triz. Corro para a borda do campo para não ser queimado. Cleonice joga a bola em minha direção e a bola deixa uma marca de terra em minha camiseta branca. As crianças riem. Pego a bola, cruzo o campo adversário e lanço a bola para o meu time. Enquanto a bola está com a gente é a vez do outro time ser alvo, o que os leva a ficar correndo de uma borda a outra no campo. As pessoas do nosso time se espalham entre o campo ao invés de correr todas para o mesmo lado e ficam revezando a vez de quem lança a bola para o outro lado.

As marcações dos espaços na queimada se diferem muito do espaço do Pique Cola 
Americano. As crianças também correm na queimada. Porém, a corrida na queimada é delimitada por uma área, por um campo medido em passos. Quando a bola está com o adversário, os jogadores correm em direção às bordas, aos limites do campo, para não serem atingidos pela bola. Quando a bola está com o próprio time, os jogadores se espalham mais dentro da área. A direção para onde os jogadores correm depende não só da bola, como do campo que ela parte. Novamente, retomo a diferença entre limite-contorno e limite-tensão de Deleuze (1981). No pique-cola americano, a brincadeira é orientada somente por limites-tensão, que só agem no limite da sua potência. Na queimada, os limites-tensão ainda estão presentes: a bola, que produz o movimento dos times, só age no limite de sua força e da intensidade com que é jogada. Diferente do pique cola, a queimada também produz limites-contorno, das bordas do campo. Estes limites dimensionalmente fixados são relativamente fixos e produzem as áreas dos times.

Enquanto Alberto, Verônica, Leonardo, Cleonice e André ficam correndo de um lado para o outro para fugir da bola, o café-com-leite Caetano se diverte com uma garrafa de plástico. O menino enche a garrafa com a terra vermelha, anda um pouco e despeja a terra no chão. Em alguns momentos ele até cruza o campo adversário sem grandes prejuízos para o jogo. Victor presta atenção no amigo com a garrafa e pega um pouco de terra com a mão. Quando a bola finalmente para no seu campo, o menino solta a terra e reclama que não lançou a bola ainda. Lucas, contrariado, entrega a bola para ele. O menino faz um lançamento bem fraco e a bola vai direto para o chão no campo adversário. O jogo continua.

Os café-com-leite prestam menos atenção nos limites que contornam os campos da queimada. O zanzar de Caetano e de Victor tomam direções muito diferentes dos outros jogadores de seu time, que correm de um lado para o outro. Mesmo assim, a participação de Victor é garantida quando ele nota que está muito tempo sem encostar na bola e pede para lançá-la. Eles fazem parte da queimada e, ao mesmo tempo, de outros jogos com a garrafa, com a terra, etc. Fians chega a relatar uma ocasião em que uma brincadeira esteve "dentro da outra". Quando o autor perguntou o que o menino que subiu no muro durante a queimada na escola estava fazendo, recebeu a seguinte resposta: "Eu estou fingindo que aqui está cheio de lava e que ali é normal, aí eu estou pensando em como eu vou para lá sem cair na lava.” (FIANS, 2015: 70) A cena que poderia ser tirada de um filme de aventura coexistia com um jogo de queimada.

Por estarem em várias brincadeiras ao mesmo tempo, a corrida dessas crianças menores segue trajetórias bem diferentes das que correm de um limite ao outro no campo, mais focadas em não serem queimadas. Diferente do dominó, a simultaneidade de jogos e brincadeiras diferentes não configura para os outros jogadores que Victor e Caetano não saibam brincar. Implica em uma participação específica, na figura do café-com-leite. "Não pode jogar a bola forte neles" e os 
jogadores fazem vista grossa se eles passam para o outro campo. Jogando com cafés-com-leite, o bom jogador não é aquele que faz de tudo para vencer. $\mathrm{O}$ bom jogador é aquele que está atento às especificidades que envolvem a participação de cada um, mesmo que eventualmente isso signifique perder o domínio da bola para o adversário.

A convivência de diferentes idades - Caetano de cinco e Alberto com aproximadamente quarenta anos - na queimada prescinde da simultaneidade de outros jogos e brincadeiras. No dominó do Buriti dificilmente seria aceito com tranquilidade que outras brincadeiras simultâneas influíssem nos rumos do jogo, como fingir que algumas pedras estavam com lava ou jogar terra no meio do jogo com uma garrafa. Isso tem tudo a ver com a diferença entre jogo e brincadeira que pego emprestado de Benjamin. Quanto mais se leva a sério o jogo ou a brincadeira, menor é o espaço para os café-com-leite, ou seja, quanto mais se esquece que o importante da brincadeira é brincar, menos brincadeiras diferentes cabem dentro do jogo.

A distinção entre adulto e criança some na brincadeira. Alberto e eu participamos da brincadeira como Cleonice ou Caetano. Dependendo do jogo, crianças muito pequenas não sabem jogar por não dominarem as regras. Por outro lado, a brincadeira não é restrita às crianças e nem mesmo aos seres humanos (BATESON, 1972). As diferenças entre café-com-leite e os outros brincantes são manejadas dentro da brincadeira na medida em que elas se apresentam.

Jogamos algumas vezes queimadas até que começou a escurecer. Lorena, Leonardo e Lucas foram para casa, pois Eliana não gosta que voltem a noite. Alberto aproveitou para ir para casa também. Cleonice sugere que brinquemos de tourinho, uma brincadeira que conheci no acampamento. Primeiro as crianças escolheram Verônica para ser o touro. Depois demos as mãos e fizemos uma roda. Verônica correu em direção às mãos de Cleonice e Felipe, que seguraram com muita força, não a deixando escapar. Depois disso, a adolescente correu entre minha mão e a de Victor. Também seguramos o máximo que conseguimos. Victor não aguentou e soltou a mão. A adolescente conseguiu sair do círculo e me escolheu para ir para o centro. As crianças riam bastante. Entrei para o meio da roda, que já não estava no mesmo lugar do início da brincadeira. Corri entre Verônica e André, que seguraram firme. Depois peguei impulso, corri entre Kethlen e Cleonice e consegui sair do círculo e escolhi Victor (quatro anos) para ir para o meio.

Victor corria para um lado da roda e depois para a outra ponta. Sua força era muito pequena para romper as mãos dadas das outras brincantes. O menino procurou Caetano, que é de sua idade e dava as mãos a Kethlen, correu, forçou a saída, mas não conseguiu. Tentou novamente sair da roda entre Cleonice e Felipe. Depois de forçar um pouco, Cleonice libera para que o menino consiga sair. Depois de brincarmos mais um pouco, foi a vez de Caetano entrar na roda. Assim como Victor, Caetano forçava a sua saída entre os braços das outras crianças e não conseguia sair. Depois de 
muito forçar, Verônica deixou o menino escapar.

Deixar Victor escapar permite que o fluxo da brincadeira não se interrompa. Se Victor ficasse para sempre dentro da roda, rapidamente perderia graça. No entanto, tirar as crianças pequenas da brincadeira por não terem força o suficiente está fora de cogitação. Como no café-comleite, para saber-brincar é necessário abdicar do objetivo do jogo, que é impedir que o touro escape, para que a brincadeira continue. Saber brincar com as crianças pequenas envolve a postura de abdicar, por um instante, das regras do jogo. Saber brincar envolve, em algum momento, abdicar de vencer.

\section{Brincando com fogo}

No caminho para a casa de Chico indo visitá-lo, encontrei Alberto saindo de sua casa. Ele estava ofegante e cansado. $\mathrm{O}$ militante me disse sobre a luta para apagar as chamas. $\mathrm{O}$ incêndio se alastrou em torno da casa de Chico e só não teria pegado no barraco porque os vizinhos se mobilizaram. Olhei a frente e notei que no caminho para a casa de Chico o mato estava preto. Os bombeiros saíram minutos antes de eu chegar, disse Alberto. Mais ansioso ainda para saber como estava Chico, me apressei para encontrá-lo. Encontrei-o levando os coelhos e os patos que cria de volta para seu barraco. O militante pediu minha ajuda para levar as gaiolas.

Chico: Me dá uma ajudinha aqui, Gustavo?

Gustavo: Claro! Alberto falou do incêndio.

Chico: É, quase perco o barraco. Ia dormir lá na praça hoje e não vou poder mais pra ficar arrumando aqui. Deu tempo de salvar os coelhos e os patos.

Gustavo: E como é que foi que aconteceu?

Chico: O menino da Dona Rosa. Tava brincando com fogo do lado de fora. Alastrou rapidão com esse mato seco e com esses troncos. Os bombeiros falaram que esses eucaliptos que tão derrubados pegam fogo rápido. Tem que falar pra empresa que não dá mais pra deixar assim derrubado e vim buscar só no outro dia mais não.

Deixamos as gaiolas no chão de sua casa. A estrutura externa que abriga os coelhos tinha algumas partes queimadas. Chico estava cansado. Pegou um copo de água na cozinha, sentou-se a mesa e convidou-me para sentar. Não queria incomodar alguém que instantes antes teve seu quintal incendiado. 
Chico: Se os vizinhos não tivessem ajudado, tinha perdido o barraco hoje. Os bombeiros perguntaram se eu queria acionar o Conselho Tutelar e fazer uma denúncia sobre o menino. Mas pra que eu ia fazer isso? Só pra criar dor de cabeça pra ela? Decidi não fazer. Parece que o menino tava brincando de colocar fogo no lixo. A Dona Rosa disse que chegou até a ver, mas ela achou que não teria problema. O fogo cresceu rápido.

Brincar pode ser perigoso. Ainda mais entre eucaliptos. Brincar com fogo é uma expressão muito utilizada quando não se leva o perigo a sério. $O$ fogo foge do controle, espalha-se rapidamente. Uma simples distração leva o as chamas a consumirem grandes áreas em pouco tempo. Os eucaliptos a redor, bastante inflamáveis, tornam a brincadeira com fogo mais perigosa do que ela já. Dona Rosa não parece ter tanto medo quanto eu de deixar uma criança brincar com fogo. Ela chegou a ver Felipe, de oito anos, brincando de atear fogo no lixo.

\section{Brincando com as regras do jogo}

Se Tambiah (2013) apresenta dois ordenamentos do mundo baseados nos princípios da causalidade ou da participação, poderíamos igualmente sugerir que existiriam duas orientações gerais que aparecem nas brincadeiras. Por um lado, a brincadeira balizada predominantemente pela mensagem metacomunicativa "estamos brincando", orientado por uma comunicação não-denotativa (BATESON, 1972). Esta mensagem comunica que os signos não devem ser levada a sério. Por outro lado, o que Benjamin chama de jogos, em que o conteúdo imaginativo está predominantemente contido em regras pré-fixadas. Os jogos operam por um registro naturalista do como é, exatamente como está nas regras e a mensagem “isso é uma brincadeira” é suspensa.

A distinção entre jogo e brincadeira trabalhada aqui se parece com a distinção faz Bispo ${ }^{21}$ :

“O jogo de futebol é regido por regras estáticas e pré-definidas, onde vinte e duas pessoas jogam, uma pessoa julga e milhares de pessoas assistem. Pode ocorrer que entre as pessoas que assistem exista alguém que jogue melhor que uma das vinte e duas pessoas que estão jogando. Mesmo assim dificilmente esse alguém poderá entrar no jogo. Numa roda de capoeira, regida pelos ensinamentos de vida, podemos ter cinquenta pessoas jogando, uma pessoa ensinando e pouquíssimas assistindo. Entre as

21 Antônio Bispo dos Santos é lavrador, morador do Quilombo Saco-Curtume, localizado no município de São João do Piauí/PI. Tem forte expressão no movimento quilombola e no movimento de luta pela terra. Possui o Ensino Fundamental Completo e faz parte da primeira geração da família da sua mãe que teve acesso à alfabetização. (BISPO, 2015) 
poucas pessoas que assistem pode haver alguma que nunca viu a capoeira. No entanto, se esta quiser, ela pode entrar na roda e jogar.” (BISPO, 2015: 42)

A rigidez nas regras "estáticas e pré-definidas" no jogo de futebol se relaciona, para Bispo, com a restrição que o futebol - profissional talvez - coloca para que as pessoas participem dele. As pessoas que ficam de fora podem assistir, mas dificilmente participar do jogo. Em vez de regido por regras prédefinidas, a capoeira é regida pelos ensinamentos da vida. A participação na capoeira se aproxima da participação na queimada com os café-com-leite, em que mesmo nunca tendo jogado, entrar na roda é permitido, mesmo para crianças pequenas poderíamos adicionar. Enquanto para Vygotsky, as brincadeiras com regras ocultas evoluem invariavelmente para brincadeiras com regras às claras ao longo do desenvolvimento da criança, para Bispo, não faz sentido essa evolução. O autor demarca uma diferença entre quem leva a sério demais as regras e quem prima mais pela participação, a despeito das regras. Essa diferença não é devido a uma evolução, mas sim por cosmovisões distintas que organizam as experiências coletivas (BISPO, 2015).

É importante ressaltar que a relação com as regras não é totalizante em nenhuma brincadeira. $\mathrm{Na}$ queimada, Leonardo e Lucas às vezes levavam a brincadeira muito a sério e jogavam a bola forte demais. Mesmo tendo expulsado o menino Caetano por não saber as regras, a linguagem não-denotativa e os blefes faziam parte do jogo de dominó. Na terminologia de Benjamin (2009) brincadeira e jogo possuem sentidos opostos. As brincadeiras no Canaã e na praça do Buriti mostram que elas podem acabar se tornando jogos, os jogos podem desdobrar-se em brincadeiras. Talvez exista futebol na capoeira e capoeira no futebol.

Adotando esta perspectiva de relativização da importância das regras nas brincadeiras, desmoronam os pressupostos dos estudos que focam na socialização e no desenvolvimento cognitivo. No lugar de uma atividade que permite as crianças aprender a desempenhar papéis, regras, reproduzir e interpretar o mundo das adultas, a brincadeira é aqui entendida como passatempo compartilhado por crianças e adultos. Nas palavras de Caetano, um sonho, em que podem participar mais de uma pessoa. E que menos do que socializar crianças e desenvolver pessoas adultas, a brincadeira torna adultas e crianças mais criança. No próximo capítulo, aprofundarei mais essa discussão sobre a socialização e o tornar-se adulto/criança a partir das vivências no Canaã.

Em frente ao Palácio do Buriti, a ocupação do MST fez da praça, que comumente só serve de passagem para funcionários públicos, um espaço de cozinhar, de dormir, de jogar dominó, de nadar e de brincar. A politização do espaço da praça envolveu fazer dela o que ela não foi feita para ser, da mesma forma que Caetano transformou um isopor em carrinho. E as militantes se divertem quando ocupam praças, órgãos e terras. A ludicidade da ocupação do Buriti, com as músicas do 
movimento, as místicas, as marchas, não se distingue da brincadeira das crianças. Ambas dão força ao movimento e sentido à ocupação da praça. A pressão para que o Governo de Brasília dê celeridade aos processos de reforma agrária no Distrito Federal também é feita com brincadeira.

Não é só no DF que as brincadeiras e a ludicidade são importantes no engajamento e na luta do MST. Rosa (2011) entrevista jovens lideranças do MST e argumenta que a brincadeira e a diversão são elementos ressaltados nas entrevistas como importantes para o engajamento. "Estes temas aludem ao fato inegável na pesquisa de que a entrada no movimento também se dá por uma recusa à desesperança e à tristeza da vida cotidiana do trabalho nos canaviais" (ROSA, 2011: 54). Brincadeira é um componente da luta política.

Foi com muita música, crianças e brincadeiras também que o Canaã foi ocupado desde 2011 pelo MST. Em um território que antes foi monocultura de eucaliptos, acampadas do Movimento dos Trabalhadores Sem-Terra ocupam com seus barracos e também com brincadeiras. Os moradores fizeram um campinho, marcam no chão os campos da queimada na hora de jogar, não correm para perto da igreja mal assombrada no pique cola. 


\section{CAPÍTULO III \\ "SOU CRIANÇA TAMBÉM"}

"Quem teve a ideia de cortar o tempo em fatias, a que se deu o nome de ano, foi um indivíduo genial.

Industrializou a esperança, fazendo-a funciona no limite da exaustão Doze meses dão para qualquer ser humano se cansar e entregar os pontos

Aí entra o milagre da renovação e tudo começa outra vez com outro número e outra vontade de acreditar, que daqui para adiante vai ser diferente..."

Carlos Drummond de Andrade

Passei a manhã com Caetano assistindo desenhos animados na televisão no dia quinze de setembro. Caetano intercalava momentos de grande atenção aos desenhos animados com brincadeiras até chegar a hora de se arrumar para a escola. Mickey Mouse e o Bob Esponja estão entre seus desenhos preferidos. Os desenhos passam na SBT no programa Bom dia e cia, apresentado por duas crianças. Por volta das 11:20, enquanto passava Bob Esponja, Dona Rita chamou Caetano para o banho:

Dona Rita: Vem banhar, Caetano!

Caetano: Não mãe. Deixa terminar Bob Esponja.

Dona Rita: Bob Esponja termina muito tarde.

A mãe pegou o menino pelo braço, levou até a área externa do barraco, o despiu e o colocou em um balde que já continha água morna. O menino com cara emburrada de não poder ver Bob Esponja logo começa a se divertir com a água do balde. Por ser menor, Caetano não toma banho no banheiro e sim dentro do balde, usando-o como uma banheira. Dona Rita pega um pouco de sabão e esfrega no corpo do menino e em seu cabelo. Depois de um tempo do menino brincando no balde, a mãe o tira do banho com a toalha, o seca e o veste com o uniforme da escola.

Subimos para a portaria do acampamento e encontramos Lorena e Cleonice, ambas levando crianças menores Luisa e Victor. Dona Rita aguardou com a gente na portaria até meio dia que é quando um dos ônibus chega. Perguntei para Lorena se ela iria no ônibus com a gente. Ela respondeu que vai para a escola "no ônibus dos grandes". Surpreso com a notícia de que existia um ônibus para as crianças menores e outro para as crianças maiores, eu pergunto à menina por que 
existem dois ônibus diferentes. Lorena me responde que "os maiores não cuidam deles (os pequenos)."

Quando o ônibus dos menores chegou, Caetano, Luisa e Victor entraram com ajuda da monitora do ônibus. Explico para a monitora que estava fazendo uma pesquisa pela Universidade de Brasília e pergunto se poderia entrar no ônibus com as crianças. Ela autoriza e eu sentei atrás de Caetano e Victor. O ônibus estava vazio com exceção das crianças do Canaã. A monitora colocou o cinto de segurança das crianças enquanto o ônibus partiu para buscar outras crianças. Passamos por outros acampamentos e pequenas chácaras buscando crianças, todas entre 4, 5 e 6 anos, e enchendo o ônibus. Um menino senta do meu lado e conversa com Victor, que estava atrás:

Victor: Sua casa tem manga assim? - apontando para as mangueiras do caminho.

Menino: Tem sim. E a sua?

Victor: Tem outros pé.

Menino: Ainda bem que não fui trabalhar hoje...

Gustavo: Você trabalha de que?

Menino: Faço massa, faço cimento e meu primo fica lá brincando... (em tom de chateação)

Gustavo: Quantos anos ele tem?

Menino: 3 anos... Você vai para a sala de quatro ou de cinco anos?

Gustavo: Vou na de quatro. E você?

Menino: Na de cinco anos

O "ônibus dos menores" passou nas estradas de terra buscando crianças trabalhadoras, crianças camponesas, crianças donas-de-casa. Elas se dirigem junto ao professor para turma de quatro ou de cinco anos. As crianças maiores e os adolescentes, também trabalhadoras e trabalhadores, vão no "ônibus dos maiores", que sai logo depois. E os trabalhadores adultos pegam o ônibus de linha para ir à mesma escola no turno da noite. O escalonamento de idades combinado com a fala "ainda bem que não fui trabalhar hoje", do menino de cinco anos, me despertou para uma incongruência de duas concepções distintas de infância e de tempo, que serão abordadas ao longo deste capítulo. Primeiro, confrontarei a situação do trabalho na infância com a concepção de tempo e infância de Jean Piaget. Depois, discutirei as consequências desta concepção de tempo e de infância na escola a partir de uma aula sobre higiene, presenciada durante a pesquisa. Por último, discutirei outra concepção de infância e de tempo vivido, destoante do tempo linear e da infância moderna pretensamente universal. 


\section{Tempo linear e crianças trabalhadoras}

Pires (2012) explora o trabalho de crianças a partir da etnografia realizada na cidade de Catingueira, no interior paraibano. Compreendendo que a pobreza não é a principal razão do trabalho das crianças camponesas, Pires chama atenção para uma diferença na concepção de infância e na lógica familiar camponesa para a existência do trabalho infantil no campo. Em Catingueira, é comum que as meninas peguem tarefas domésticas como limpar a casa ou cuidar de irmãos menores e os meninos peguem tarefas na lavoura e também algumas tarefas no cuidado de irmãos menores, na falta de uma irmã que faça isso. O trabalho é entendido a partir de um caráter educativo. Crianças que não "ajudam em casa” podem se tornar adultas preguiçosas ou inaptas para as atividades cotidianas. Trabalhar desde cedo é importante para a formação do caráter nesta perspectiva. A autora diz também que observou que algumas crianças de Catingueira disseram a ela que se divertiam trabalhando, principalmente quando acompanhadas de outras crianças. $\mathrm{O}$ trabalho é fundamental para a convivência intergeracional e revela outra concepção do lugar da infância:

"Nesse sentido, devemos enfatizar os padrões de dependência intergeracionais que sustentam a casa sertaneja, na medida em que mostramos a importância das crianças na manutenção e na reprodução social e material das famílias. Ao mesmo tempo, entende-se por que o trabalho realizado pelas crianças na manutenção da sua unidade doméstica e os serviços prestados ao grupo familiar extenso ou à comunidade não são entendidos como exploração, mas sim como cooperação (Fortes 1938). Desta forma, esses trabalhos e serviços são tidos como "ajuda" e não "trabalho" propriamente, mas não são desvalorizados, como parece ser o caso do trabalho das mulheres em relação ao dos homens (Heredia 1979).” (PIRES, 2012)

Esse reconhecimento da importância do trabalho de crianças na dinâmica da vida rural não significa naturalizar a desigualdade social que produz crianças que trabalham e as que não precisam de trabalhar. Também não implica em negar qualquer tipo de exploração econômica relacionada ao trabalho de crianças em casa ou na lavoura. Até porque a exploração do trabalho, em uma chave marxista, é inerente a um modo de produção capitalista, e é mais acentuada para mulheres, para crianças, negros, etc. No entanto, a existência do trabalho de crianças no meio rural não se resume a sua faceta econômica. Ela está relacionado a uma noção de pessoa, de infância, de família e de relações intergeracionais que não coincide com a perspectiva moderna.

Como na cidade da Paraíba, algumas das crianças do acampamento em Brazlândia se ocupam de atividades domésticas e em alguns trabalhos. Os filhos de Eliana já deixaram de sair 
para brincar por estarem lavando a louça ou limpando a casa. Verônica e Cleonice se animavam toda vez que saíam para fazer a colheita de morangos nas plantações próximas ao acampamento. Verônica inclusive combinou com sua mãe de plantar morango em uma parte da futura parcela e de ensinar o adulto Alberto a técnica deste plantio. Caetano e Luisa ajudam a segurar o funil quando suas mães, irmãs e irmãos mais velhos pegam água que chega do caminhão-pipa. O menino que sentou do meu lado no "ônibus dos menores" não era de um acampamento do MST, mas também trabalha fazendo massa e cimento.

Como defende Ariès (1981), o sentimento de infância moderno tem uma localização histórica e geográfica específica. Assim, é particular a noção de que a infância é uma fase de escolarização, de preparação para a vida política e econômica futura e apartada do mundo adulto. A perspectiva das pessoas do Canaã confronta uma noção de infância em que o trabalho deve ser evitado. A escola é este espaço de apartação de crianças e adultas por excelência na modernidade, em contraposição com o mercado de trabalho. A importância do trabalho das crianças em Catingueira e no Canaã desestabilizam essa noção de infância não só por entender que é desejável que as crianças trabalhem como por questionar a apartação de uma fase especialmente voltada para a preparação para a vida adulta.

A relação das crianças com o trabalho no Canaã também confrontam diretamente a concepção do desenvolvimento biológico e psíquico de boa parte dos autores de Psicologia do Desenvolvimento. Nestes estudos as idades das crianças e dos adolescentes é crucial para analisar suas aptidões e capacidades. Convencionou-se relacionar as etapas da infância a partir de uma linha do tempo fixada ao nascer. A medida de anos de vida indica universalmente que conteúdos a criança deve saber, que capacidades deve ter. A diferença entre crianças e adultos é concebida partindo de um argumento evolucionista. Esta perspectiva tem seu ápice na produção de Piaget. Para este autor, o pensamento do adulto supera o pensamento infantil em suas capacidades motoras, cognitivas e habilidades e a mudança de pensamento ao crescer é comparável com a "evolução da sociedade":

"Na nossa opinião, não acreditamos que estas possíveis semelhanças entre o pensamento da criança e o dos primitivos (veremos mais longe com a física grega) sejam devidos a uma hereditariedade qualquer. A permanência das leis do desenvolvimento mental são suficientes para explicar estas convergências, e como todos os homens, incluindo os "primitivos", começaram sendo crianças, o pensamento infantil precede o de nossos longínquos antepassados, do mesmo modo que precede o nosso.” (PIAGET, 2006: 32)

Na escola e na concepção piagetiana, as crianças são divididas em uma ordem crescente de 
idades. O tempo é linear e ordenado como uma sucessão de instantes, em que o instante 0 dessa linha do tempo se inicia com o nascimento e os instantes que seguem são marcados pelo número de anos decorridos desde o nascimento. As crianças que possuem uma determinada idade, mas ainda não possuem as capacidades epistêmicas esperadas para aquela idade são consideradas 'atrasadas', enquanto àquelas que apresentam desenvolvimento cognitivo à frente de sua idade são consideradas 'superdotadas' ou 'adiantadas'22. Para Piaget (2006), as crianças confundem realidade e fantasia até os sete anos e só conseguem operar com conceitos e ideias a partir dos doze anos. O início do trabalho é o marcador que diferencia adolescentes e adultos (PIAGET, 2006). O trabalho das crianças só pode ser entendido enquanto uma precocidade, uma degeneração do desenvolvimento saudável que leva a criança a ser adulta.

A rigidez teórica de Piaget não se sustenta quando confrontada com a realidade de que o trabalho é realidade em diversos contextos. Como pretendo desenvolver no restante deste capítulo, o trabalho de crianças no Canaã bate de frente não só com a noção universal de infância, como também da fórmula de etapas cognitivas sucessivas e hierarquicamente ordenadas. A fórmula de que primitivas precedem civilizadas, crianças precedem adultas e estudo precede trabalho é quebrada junto com a linearidade do tempo. Crianças e adultos convivem em um mesmo espaço e em um mesmo tempo. Como direi a frente, em vez de ontologias distintas dispostas em uma linha do tempo, crianças e adultos compartilham de substâncias em comum e estabelecem relações no presente, assim como no passado e no futuro.

\section{Desenho do banho: a escola é uma merda}

O ônibus chegou na escola pouco antes das 13 horas. A monitora guiou as crianças para fora do ônibus em fila, de meninos e de meninas. Quando as crianças chegam no pátio, elas se dividem entre as turmas de 4 e de 5 anos. Caetano e Luisa vão para a turma de quatro anos, com o professor José. Apresentei-me ao professor José e pergunto se poderia acompanhar a turma naquele dia e ele responde prontamente que autoriza. O professor guia a fila dos meninos e a fila das meninas até a sala. As carteiras da sala são em tamanho pequeno e estavam dispostas em cinco grupos de cinco cadeiras cada. Acima do quadro, as letras do alfabeto em diferentes cores vibrantes. No fundo da sala, um armário de duas portas onde o professor guarda os materiais pedagógicos e um recipiente

22 "Traduzindo o problema do tempo como sendo de desenvolvimento cognitivo, Piaget caracteriza a criança por certas estruturas intelectuais que tendem a ser integradas e subordinadas ao modo adulto de conhecer, representado pelas estruturas lógico-matemáticas. (...) Buscando encontrar as estruturas lógicas da criança, encontra uma pré-lógica ou semi-lógica, que evidencia um déficit ou uma falta, que será ultrapassada pelo modo adulto de conhecer" (KASTRUP, 2000: 374). 
de plástico com palitos de picolé pintados de vermelho e azul.

Logo ao chegar na sala, as crianças colocam suas mochilas no fundo da sala e sentam em suas carteiras. Sentei-me em uma carteira no fundo da sala que não estava em nenhum grupo. O professor pega os palitos vermelhos e azuis no fundo da sala e diz: "Bom dia turma! Vamos contar quantas meninas e quantos meninos vieram hoje?” O professor distribuiu os palitos vermelhos para as meninas e os palitos azuis para os meninos. "Vamos começar contando quantas meninas vieram?” O professor começa a recolher um a um dos palitos vermelhos e conta em voz alta: “Um, dois... Contem comigo!". A turma segue contando "três, quatro... nove". O professor coloca um nove no quadro. Recolhe os palitos azuis dos meninos, conta com a turma os sete meninos presentes e coloca o número no quadro.

José: Quem pode agora contar quantas crianças vieram hoje?

Mateus: Eu!

José: Então vai Mateus. (Mateus levanta-se da sua carteira, conta três crianças de seu grupo, pula uma menina, conta duas crianças do grupo do lado, volta para o seu grupo e conta a menina que faltava, segue para os outros grupos)

Mateus: Catorze.

José: E com você?

Mateus: Quinze.

José: Faltou um. Você não fez aquele caminho que eu ensinei. Quem pode agora?

Luisa: Eu! (Luisa também se levanta, faz um trajeto pela sala e chega a sua conta) Doze.

José: E com você?

Luisa: Treze.

José: Vocês não tão fazendo aquele caminho que a gente treinou com o barbante.

Posteriormente, o professor me explicou que as crianças dessa idade "não tem noção de espaço", querendo com isso dizer que elas "pulam", deixando sem contar colegas que estavam "no vazio". A atividade de percorrer por um barbante a sala para que, nesse trajeto, a criança dê conta de contar todas as outras crianças da sala visa o desenvolvimento dessa noção espacial total. Para Piaget (2006), antes dos sete anos, a noção de espaço é autocentrada, ou seja, espaço é tudo que a criança consegue ver. A construção de um espaço racional, "homogêneo" e "isotrópico", da forma como é ensinado nas escolas, coincide com o que é concebido pelo INCRA na divisão de parcelas. Depois de iniciar a aula com a contagem das crianças presentes, como de costume, o professor José iniciou propriamente o tema do dia. 
José: Hoje a gente vai falar de higiene. (O professor desenha um chuveiro no quadro)Alguém sabe o que é isso?

Algumas crianças em coro: Chuveeiro!

José: Isso mesmo. E isso aqui?

Stéfani: Escova

José: Isso mesmo Stéfani. Higiene é o que a gente faz para ficar limpinho, cheiroso... Agora a gente vai desenhar a gente tomando banho. (O professor pega umas folhas de papel no armário, lápis e entrega para as crianças)

As crianças começam a desenhar. Noto com estranheza o comportamento de Caetano na sala de aula. O menino está muito mais quieto e menos agitado do que estava acostumado. O professor se aproxima de Luisa e pergunta “O que você tá desenhando, Luisa?” A menina do Canaã responde "Minha mãe banhando eu e o Luã". O professor elogia o chuveiro desenhado por Luisa. Os traços fortes do desenho do banho de Luisa não trazem os baldes que vi pela manhã na casa de Caetano. No desenho (número 1), a mãe dá banho na menina e no seu irmão mais novo em um chuveiro pequeno, próximo a cabeça.
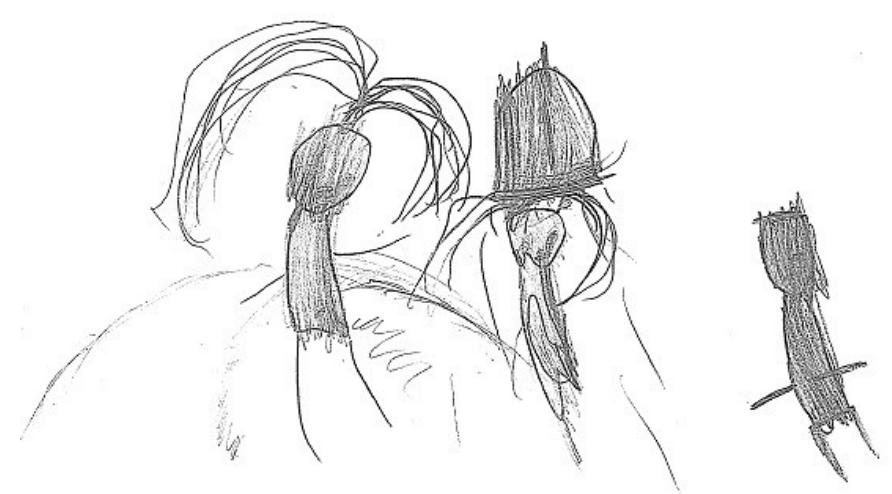

Desenho 1 - Desenho do banho 
Caetano fez um desenho um pouco diferente do resto da turma. O menino desenhou o Bob Esponja, um vaso e a chuva. Nada de chuveiro.

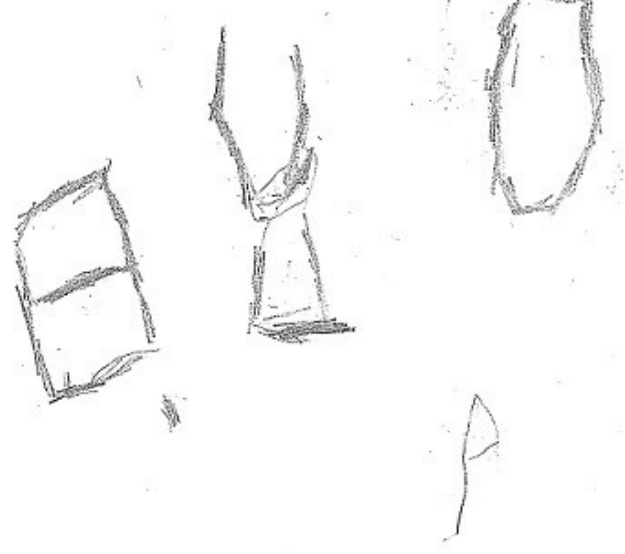

Desenho 2 - Bob Esponja, chuva e o vaso na hora do banho

O professor recolheu os desenhos ${ }^{23}$, organizou a fila para a aula de educação física e levou as crianças para fora da sala, onde o professor de educação física as aguardava.

Noções hegemônicas de tempo e transformação das crianças na escola se assemelham ao que lemos nas teorias evolucionistas de Piaget. Ao completar cinco anos, as crianças capazes de ter noções de espaço mais determinadas, de contar e saber a ordem dos números, de reconhecerem formas geométricas e de ter noções de higiene. Nesse conjunto de aprendizados e capacidades alocados em uma linha do tempo cognitiva, algumas crianças têm um rendimento menor, estão 'atrasadas' em relação às outras.

Contudo, colocados em uma lógica linear de evolução, esses aprendizados não levam em consideração outras possibilidades de conhecer, outras perspectivas de espaço, de tempo de vida. Para o professor, a hora do banho é um assunto de higiene e, por isso, desenhá-la consiste em trazer o chuveiro, o sabonete e o xampu. Para Caetano, a hora do banho vai muito além da higiene. No

23 Nesse momento, José perguntou se eu tinha interesse em ficar com os desenhos. Disse a ele que sim. Posteriormente, pedi autorização para as mães das duas crianças para usá-los na dissertação. 
espaço do menino, o banho tem balde, Bob Esponja e um vaso. Caetano mostra que não existe uma maneira única de entender o banho. Da mesma forma, quando Luisa percorre a sala de aula, ela mostra que o espaço da sala de aula oferece muitas outras oportunidades do que somente o caminho do professor. O professor quer que as crianças levem em conta tudo o que tem no espaço. No entanto, não está preparado para se deparar com outros conhecimentos, novas coisas que estejam contidas neste "tudo".

Além do aprendizado uma noção de espaço e de tempo, existem uma infinidade de outros marcadores das etapas de desenvolvimento que variam de acordo com a perspectiva teórica. Para Freud (1973), por exemplo, saber usar o banheiro ou a curiosidade de ver os genitais das outras crianças marcam as etapas do desenvolvimento da criança. A fase anal é uma fase de aprendizado em relação ao controle do esfíncter do ânus prevista entre 1 a 3 anos. A retenção e evacuação das fezes são uma forma de estimulação prazerosa das mucosas retais e, o aprendizado deste controle do esfíncter se dá mediante a relação da criança com seus cuidadores e marca uma etapa no desenvolvimento sexual (FREUD, 1973). A curiosidade para ver os genitais das outras crianças - do outro ou do mesmo sexo - também é um marcador de uma fase do desenvolvimento infantil (FREUD, 1973). Qualquer comportamento que seja identificado com esses marcadores fora da idade esperada é um indício de atraso ou precocidade da criança em relação a estas etapas.

Ficam evidentes os alicerces evolucionistas destes autores basilares para a Psicologia do Desenvolvimento - Freud e Piaget. A noção de desenvolvimento saudável vem - ora implicitamente, ora explicitamente - associada a um parâmetro do que é civilização, em contraposição àquilo que é considerado primitivo. Não usar corretamente o banheiro pode ser considerado um sinal de atraso no desenvolvimento psicológico ou um comportamento próprio da idade. Nesta visão de mundo não é possível admitir que o próprio padrão estabelecido de "uso correto" não é universal. Crianças que trazem de casa outras noções de tempo, de espaço, outras conformações de banheiro - ou mesmo sua ausência - outras relações com o corpo e com a sexualidade são encaixadas nessa linha do tempo do desenvolvimento infantil. Ao se depararem com uma maneira única de descrever o espaço ou de fazer cocô, elas se defrontam com uma classificação de seus aprendizados e na sua relação com o próprio corpo. Crianças indígenas, camponeses e de outras "culturas" consideradas atrasadas em termos civilizatórios também são assimiladas enquanto atrasadas em seu desenvolvimento cognitivo, psicológico e sexual. Para crianças acostumadas a evacuar na terra, a escola pode ser uma merda.

Depois das crianças voltarem da aula de educação física. O professor José passou o desenho dos três porquinhos para as crianças. O desenho conta a história de três porcos irmãos que constroem suas casas. Um deles faz a casa de palha, o segundo faz a casa de madeira e o terceiro, 
mais esperto, faz a casa de tijolos. Com a vontade de comer os porquinhos, o lobo mau vai primeiro na casa de palha. Facilmente a derruba com um sopro intenso. O porquinho dessa casa corre para a casa de madeira de seu irmão. Novamente, o lobo mau com um sopro vigoroso bota a casa de madeira no chão. Os dois porquinhos correm para a casa de tijolos, em que o sopro do lobo mau não surte efeito tamanha é a solidez de uma casa de tijolos. O desenho termina com o entoar repetitivo do verso “Quem tem medo de lobo mau?" Caetano e Luisa assistiram com atenção. Depois do desenho, as crianças brincaram com os brinquedos da sala por uns quarenta minutos até chegar a hora de novamente entrar no ônibus e voltar para casa. Chegando no acampamento, vimos Eliana e Rosa indo para o ponto de ônibus para ir para a escola no turno dos jovens e adultas.

No Canaã, as brincadeiras, a ação política do movimento e o trabalho não possuem essa relação com o tempo. Enquanto na escola, as crianças podiam ser atrasadas e adiantadas, no acampamento, as crianças podiam ser somente diferentes. A convivência entre diferentes idades não fazia de ninguém à frente ou atrás no tempo. Adultos podiam ser crianças e entrar na brincadeira sem qualquer relação com suas capacidades.

\section{Guerra de pipoca}

Acordei cedo naquela manhã em setembro com o barulho de uma motosserra. Um trabalhador cortava um eucalipto lá fora. Achei o som alto e tive a impressão de que de tão perto o eucalipto poderia cair no barraco. Fui para a sala e perguntei para Verônica do barulho. Ela confirmou que as motosserras começam cedo no acampamento. "E esse não tá muito perto do barraco não?" Verônica deu risada. "Mainha, Gustavo tá com medo da árvore cair aqui em casa". Dona Rita deu risada também. Mais tarde, quando fui lá fora, a chacota justificou-se. O eucalipto que estava sendo retirado estava a cerca de cinquenta metros.

No resto da manhã, tudo transcorreu como de habitual. Verônica foi cedo para a escola. Dona Rita foi lavar roupa. Caetano foi assistir os desenhos na televisão. Pouco depois das onze horas, Caetano não queria ir para o banho e Dona Rita o levou para o balde. A mãe arrumou o menino para a escola e eu o levei para a portaria para esperarmos juntos o ônibus dos menores. $\mathrm{O}$ ônibus passou em outros acampamentos, assentamentos e chácaras buscando outras crianças. Caetano estava sentado ao meu lado e pediu para eu colocar o cinto de segurança. Expliquei para ele que o cinto era muito pequeno para mim. Foi então que uma menina da turma de Caetano, Bianca, me questionou: 
Bianca: Você vai estudar? Você tá nos ônibus dos menores por quê?

Gustavo: É. Eu sou criança. - disse em tom de brincadeira curioso para ver onde ela levaria.

Bianca: Criança? Cadê sua mochila de ir para a escola?

Gustavo: Olha aqui meu caderno - apontando para o diário de campo. O menino da frente entrou na conversa também.

Menino: Nunca vi criança de bigode!

Bianca: Você tem carteira. - disse ela apontando para meu bolso - Você não é criança.

Ao chegar na escola, na saída do ônibus, Bianca voltou a levar a sério o que eu tinha dito. "Você fica na fila dos meninos!" A menina indicou que para ser criança, teria que agir como uma. Desfazer-me da carteira, do bigode, usar mochila e entrar na fila. Além de estar no ônibus dos menores, eu deveria usar o cinto. A possibilidade de me deparar com diferentes concepções de infância já tinha sido alertada pela literatura (COHN, 2013; BUSS-SIMÃO, 2009, TASSINARI, 2009). A pressuposição de uma concepção universal de infância pode incorrer em diversos apagamentos das multiplicidades de ser criança em diferentes lugares e para diferentes pessoas. Com essa multiplicidade, para discutir o que é ser criança, Cohn (2013) propõe dois caminhos a serem explorados pelos pesquisadores: investigar como se define a infância (ou as infâncias) nos lugares em que se faz pesquisa, e como as crianças, informadas por tais concepções de infância, atuam e produzem noções de infância. As ideias da autora são a de reconhecer que as crianças são agentes sociais plenas e de que as concepções de infância dos diferentes lugares balizam essas vivências de ser criança (COHN, 2013).

Porém, mais do que uma classificação que permite identificar crianças e adultas baseada em uma concepção cultural, Bianca sugeriu que ser criança se relacionava a um fluxo que a relacionava a um conjunto de objetos, de características. A mochila, o cinto e o ônibus carregavam consigo uma substância infantil. A carteira e o bigode continham o ser adulto em sua composição. Os atributos de adultas e de crianças não implicavam para Bianca uma consequente classificação estanque, em uma taxonomia. Eu poderia ser adulto e estar no ônibus dos menores, e possivelmente uma criança que tivesse uma carteira não seria menos criança. O fluxo entre coisas de criança e de adulta transpunha a barreira do que era concebido como ser criança e ser adulta,

Essa ideia de que um conjunto de coisas possui propriedades "de criança" também apareceu em uma das visitas que fiz a Laura. Nesta ocasião, sua mãe, que mora no interior do Piauí, estava visitando a filha e os netos no acampamento Canaã e aproveitando a estadia na capital para fazer consultas no hospital. A mãe de Laura tinha por volta de 60 anos, apesar de aos meus olhos aparentar ter mais idade. Laura a apresentou para mim: 
Laura: Essa aqui é minha mãe, Gustavo.

Gustavo: Tudo bom?

Mãe de Laura: Tudo bom, meu filho?

Gustavo: Tudo certo. Tá de visita aqui?

Mãe de Laura: É. Estou sim. Vim ver o médico também.

Laura: Ela está doente...

Mãe de Laura: É. Daqui a pouco estou que nem criança... Você sabia, meu filho, que gente velha vira criança? Eu não virei criança ainda não. Falta uns anos ainda. Mas gente muito velha tem que usar fralda, tem que comer na mão dos outros. Fica dependendo dos outros sabe? Precisa dos outros pra banhar, pra trocar de roupa...

Como para Bianca, para a mãe de Laura, ser criança é uma propriedade que emerge na relação que se tem com objetos, com necessidades, em suma, com outras coisas além de si mesmo. As fraldas comportam algo de criança. A necessidade específica de cuidados também é característica de crianças. No entanto, nem a fralda nem a ajuda dos outros para tomar banho ou trocar de roupa são exclusivos das crianças. Velhos - poderíamos adicionar doentes e bêbados também desfrutam desse fluxo de cuidados para crianças. "Ser criança" não seria uma característica exclusiva das crianças.

Esta noção fluida de ser criança me surpreendeu ao máximo em um dos fins de semana em que passei filme. Naquele domingo, retornei ao Canaã com o projetor do Departamento de Antropologia da UnB, com o DVD do filme, com três refrigerantes e alguns sacos com milho de pipoca. Passei na casa de Dona Rita e falei para Verônica ir com Caetano para a igreja, onde eu passaria o filme. Chamei as crianças da casa de Eliana. Quando fui para a casa de Rosa para chamar André, Kethlen e Felipe, ela me perguntou:

Rosa: E é só para criança é? Eu posso ir também?

Gustavo: Pode!

Rosa: Eu sou criança também, sabia?

A afirmação de Rosa me deixou um pouco desconcertado. Não estava preparado para ouvir "Eu sou criança também" de uma mulher com três filhos, e mais de trinta anos. Falei para Rosa que ela poderia assistir ao filme também. Ela se animou e disse que chamaria Eliana para ver junto. No caminho para a igreja, sem entender o ponto de Rosa, fiquei imaginando se a mãe gostaria apenas 
de assistir ao filme. Será que ela achou que eu negaria a ela a possibilidade de ver o filme? "Passarse por" criança seria uma "estratégia" para conseguir comer pipoca e ver um desenho animado?

Quando chegamos na igreja, estavam todos sentados. Rosa e Eliana estavam lá. Enquanto fui montar o projetor, Eliana disse que ia estourar a pipoca. Alguns minutos depois, Eliana voltou com duas bacias de pipoca e as colocou no chão, entre as cadeiras e a imagem projetada do filme. Depois que ela voltou, coloquei o filme para começar. A animação do dia era O Menino e o Mundo, uma produção brasileira de 2014. O filme conta a história de um menino que deixa a aldeia de onde vive para encontrar seu pai, que foi tentar ganhar a vida na cidade. Algumas crianças acompanharam atentamente o filme, reagindo às ações do menino e rindo. Victor, a todo momento, levantava para pegar a pipoca da bacia no meio e parecia pouco se interessar pela animação. Leonardo e Caetano ficaram bastante atentos ao filme.

Quando acabou o filme, perguntei “O que vocês acharam?” com o propósito de saber as impressões sobre a animação. A resposta veio com o grito de Lucas: “Guerra de pipoca!”. Lucas encheu a mão com a pipoca da bacia e jogou em Cleonice. A menina respondeu com o mesmo gesto. As outras crianças entraram rapidamente na brincadeira. As pipocas eram lançadas para todos os cantos. As crianças riam. Em meio às nuvens de pipoca que entrecruzavam a igreja, olhei para Eliana e Rosa com a expectativa que elas interrompessem a brincadeira. As duas mães encheram a mão com pipoca da bacia e participaram da guerra como as outras crianças. A pipoca da bacia espalhou-se toda pelo chão da igreja. Eliana, Rosa, Verônica e eu varremos o chão depois da guerra enquanto as demais crianças foram jogar futebol no campinho lá fora.

A conversa com Rosa e sua participação na guerra de pipoca continuaram me desestabilizando. As ações de Rosa não faziam parte daquilo que é esperado de um adulto. $\mathrm{Na}$ minha expectativa, o adulto naquela ocasião seria sério, interromperia a guerra de pipoca por fazer sujeira, por dar muito trabalho. Rosa e Eliana tomaram outro caminho. Elas não imitaram uma criança. Elas entraram na brincadeira da mesma forma que as outras crianças. Isso de forma nenhuma era entendido como algo de que deveriam sentir vergonha, algo que as diminuísse. Em outra ocasião, ela voltou a afirmar ser criança. "Você estuda crianças né? Então vai ter que me estudar também.”

Assim como Bianca e a mãe de Laura, para Rosa, ser criança não tem a ver com uma classificação estanque que parte de um conceito. Passa longe de ser mensurável - não é uma diferença etária e nem de tamanho. Tem a ver com esse fluxo que conecta pessoas, coisas, brincadeiras e desenhos animados. Ser criança vem acompanhado dos movimentos da guerra de pipoca, da queimada, do pique cola. Deixar se afetar por músicas e desenhos animados também faz parte do fluxo. Tornam-se crianças por pegarem o ônibus dos menores e por usarem mochila como 
Bianca. Caetano se faz criança brincando nos banhos de balde, assistindo Bob Esponja e tendo o relógio do Ben 10. Eliana se faz criança cantando as músicas do MST e jogando pipoca em outras crianças. Rosa é criança também. Esse fluxo criança - ou devir a partir de Deleuze e Guatari (1997)- não exclui adultas ou idosas no seu movimento. Tampouco apaga as diferenças entre ser adulta e ser criança. A brincadeira da criança pode impregnar a adulta também. Mexe com a criança que nela pode vir a ser.

Igualmente ao ser criança, ser adulta não é uma categoria taxonômica. Ser adulta também é um fluxo. Em vez de conectar as pessoas com desenhos animados e brincadeiras, o adulto é feito com carteira, com bigode, com bebida alcoólica ${ }^{24}$, talvez com trabalho. Existe um movimento em sentido diverso do ser criança que é o movimento de ser adulto. E este movimento de tornar-se adulto tampouco é exclusivo das pessoas adultas, uma vez que crianças também trabalham, também bebem bebidas alcoólicas, também podem ter carteira. Existe um devir-adulto que também pode atravessar as crianças. Entre as concepções estanques do que é criança e do que é adulto cabem muitas figuras: a criança trabalhadora, o adulto analfabeto, a criança mãe, a adolescente em conflito com a lei, a liderança sem-terrinha, a mãe na guerra de pipoca e o vizinho adulto no jogo de queimada

A guerra de pipoca em que Rosa e Eliana se meteram não pode ser entendida como uma lembrança da criança que elas foram ${ }^{25}$. Não é uma regressão a um estágio anterior de sua vida. Rosa e Eliana se fizeram criança no presente simultaneamente ao movimento da guerra de pipoca. Assim como a criança que trabalha na roça não preconiza seu futuro adulto. Ela se faz adulta no presente, no movimento de seu trabalho. Estes movimentos rompem com todos postulados evolucionistas da Psicologia do Desenvolvimento de Piaget, Freud e tantos outros. A linearidade do tempo e a aposta na sucessão de estágios cognitivos ou fases do desenvolvimento sexual não consegue dar conta deste desafio sem cair nas chaves do 'atraso' mental, fixação/lembrança ou precocidade. Criança e adulto convivem e se sucedem no passado, no presente e no futuro, independente do tamanho e da idade. Todos esses tempos coexistentes formam um amálgama indivisível, tornando impossível separar a infância da fase adulta em uma linha do tempo. Ninguém é café-com-leite por estar 'atrasada' em relação ao resto. Ninguém trabalha na colheita por ser 'adiantado'. As diferenças entre as pessoas seguem um parâmetro ou um tempo linear. A convivência com as crianças em casa, no jantar, na brincadeira, nas marchas, no trabalho e no convívio que é interno a cada pessoa trata de

24 Dona Rita disse uma vez a Caetano que cachaça não era bebida para criança.

25 "Opõe-se desse ponto de vista um bloco de infância, ou um devir-criança, à lembrança de infância: "uma" criança molecular é produzida... "uma" criança coexiste conosco, numa zona de vizinhança ou num bloco de devir, numa linha de desterritorialização que nos arrasta a ambos - contrariamente à criança que fomos, da qual nos lembramos ou que fantasmamos, a criança molar da qual o adulto é o futuro.” (DELEUZE\&GUATARI, 1997: 81) 
um rompimento radical com a ideia de evolução.

O atravessamento de devires não é tangível. Não se pode localizar precisamente onde residem essas substâncias que fazem das coisas e pessoas crianças e adultos. Isso remete à conversa que tive com Verônica no dia das crianças. Neste dia, em outubro, o acampamento em frente ao Buriti persistia. Verônica e Caetano estavam brincando de tourinho com meninos e meninas de outros acampamentos. Fiquei conversando com Dona Rita até a brincadeira terminar. Passado um tempo, Verônica saiu da roda do tourinho e me cumprimentou:

Gustavo: Feliz dia das crianças!

Verônica: Acho que nunca vou deixar de ser criança. Sou muito brincalhona, que nem o Alberto.

Gustavo: Vai jogar queimada que nem ele depois de grande?

Verônica: É. Acho que todo mundo guarda uma parte do corpo de criança.

Gustavo: Ah é? E em qual parte do seu corpo tá a criança?

Verônica: Nele todo.

A criança está no corpo de Verônica e de Alberto. É parte de sua composição. Mas não é localizável como o fígado, o braço ou o estômago. A criança se espalha por todos os poros do corpo e conecta Verônica com a brincadeira. A criança não seria anatômica, mas talvez físiológica. E o envolvimento de Alberto na queimada seria, assim, fisiológico. Alberto coexiste com um fluxo de crianças que circula em seu corpo e o desterritorializa, levando-o a conviver com as crianças lá fora, a brincar com elas. A queimada é tanto externa ao corpo de Alberto quanto lhe é interna ${ }^{26}$. As crianças que habitam Alberto preparam-se para jogar queimada enquanto Verônica e Cleonice demarcam os dois campos. Elas correm de um lado para o outro simultaneamente a Alberto. Os cafés-com-leite que habitam Alberto participam quando Caetano joga a bola.

Quando o fluxo de crianças e adultas atravessa a todos, as diferenças etárias e de tamanho não são um impeditivo para a convivência. A convivência entre as idades acontece nas brincadeiras do acampamento, no trabalho nas colheitas, no momento de buscar água do caminhão-pipa e nos atos em frente ao Palácio do Buriti. Crianças e adultos produzem relações o tempo todo. As crianças

26 Conquanto seja útil reter o conceito de socialidade para referir-se à criação e manutenção de relações, no que diz respeito a contextualização das concepções melanésias necessitaremos de um vocabulário que nos permita falar em socialidade tanto no singular como no plural. Longe de serem vistas como entidades singulares, as pessoas melanésias são concebidas tanto dividual/ como individualmente. Elas contêm dentro de si uma socialidade generalizada. Com efeito, as pessoas são frequentemente construídas como o lócus plural e compósito das relações que as produzem. A pessoa singular pode ser imaginada como um microcosmo social. (STRATHERN, 2006:40 e 41) 
não são segregadas até se tornarem $\operatorname{adultas}^{27}$. Não se espera que atinjam um patamar, uma linguagem comum, uma cultura comum e que só então sejam capazes de produzir relações. Para que relações sejam produzidas do modo como são, nem o fluxo de crianças no adulto, nem o fluxo de adultos na criança, pode ser interrompido.

É justamente na interrupção desses fluxos que a escola atua. As crianças são retiradas de qualquer convívio com as adultas. E vice-versa. A cada etapa escolar, espera-se que ambas rompam com o comportamento, com o esperado do "outro" estágio; um anterior, outro posterior. Ensina-se a criança que ela não está mais no pré, que já tem idade para pintar dentro das bordas ${ }^{28}$. Cada uma é incentivada a brincar somente com outros de sua mesma classe etária.

Quebrando as dicotomias de dentro/fora, passado/futuro, brincadeira/seriedade, sociedade/indivíduo, a coexistência de crianças e adultos desafia epistemologicamente não só a Pedagogia, a Psicologia da Infância, a Psicologia do Desenvolvimento como também a Ciência Política e a Economia.

\section{E a Antropologia?}

De que forma a Antropologia lida com as diferentes formas de ser criança e de ser adulta? Cohn (2013) nos lembra que as crianças fazem parte de relatos de viajantes e missionários desde o início da colonização. Desde o início do surgimento da Antropologia, as crianças estiveram presentes, por exemplo na discussão sobre ciclos da vida (COHN, 2013). Segundo a autora, foi somente no final do século XX que a disciplina buscou estudar a criança e suas vidas por elas mesmas, ouvir o que elas têm a dizer. O apagamento da voz das crianças nas etnografias persiste sendo muito comum nos trabalhos antropológicos que não discutem propriamente com a antropologia da criança. Mesmo trabalhos que discutem ritos de passagem para a vida adulta, classes etárias, e ciclos de vida, não necessariamente levam a sério o que as crianças dizem. Os estudos com crianças indígenas, por exemplo, surtiram pouco efeito no debate da etnologia indígena

27 "Ao apresentar esses aspectos, pretendi mostrar contextos nos quais as crianças não são segregadas em "espaços educativos", mas, bem ao contrário, ocupam posições centrais e mediadoras da vida social. Se for possível fazer algumas generalizações, pode-se dizer que as crianças indígenas são elementos-chaves na socialização e na interação de grupos sociais e os adultos reconhecem nelas potencialidades que as permitem ocupar espaços de sujeitos plenos e produtores de sociabilidade. Da mesma forma, o pensamento indígena parece colocar as crianças como mediadoras entre categorias cosmológicas de grande rendimento: mortos/vivos, homens/mulheres, afins/consangüíneos, nós/outros, predação/produção. Portanto, nesses contextos, não faz sentido a separação que geralmente fazemos entre a "vida séria" e o universo infantil caracterizado pela fantasia e diversão, separação que nos dá a ilusão de que as atitudes infantis não têm conseqüências sociais." (TASSINARI, 2009: 8)

28 Um dos motivos pela qual o professor de Caetano disse que ele era atrasado em relação ao restante da turma foi pela sua incapacidade - ou escolha talvez - de pintar dentro das bordas do desenho. 
(COHN, 2013) A consolidação deste campo de estudos dentro da antropologia tem cada vez mais refletido sobre essas obliterações das vozes das crianças em detrimento das vozes dos adultos e reconhecido a agência e criatividade dessas.

No entanto, se por um lado a maior parte da antropologia não incorpora as vozes das crianças em suas pesquisas, por outro lado, o sentido dessa agência nem sempre acompanha um rompimento com a naturalização de uma alteridade fundamental entre crianças e adultas. Um conjunto de antropólogos e sociólogos aposta em uma alteridade entre crianças e adultos para advogar nas "culturas infantis" enquanto um objeto. Seria o foco destes estudos "a reprodução interpretativa entre pares" (CORSARO, 2002), ou o "reconhecimento da autonomia das formas culturais, a inventariação dos princípios geradores e das regras das culturas da infância" (SARMENTO, 2005: 374) Reconhece-se as crianças enquanto atores sociais relevantes, reificandose a alteridade entre crianças e adultas.

Diferente desta corrente, há pesquisas que conseguem virar a mesa ao incorpor os adultos em suas investigações com crianças. Pires (2007), por exemplo, relata o atrito que teve com uma vizinha durante sua pesquisa em Catingueira. Quando as crianças a visitavam, a pesquisadora lhes permitiu fazer coisas que, em geral, um adulto não deveria assentir. Em sua casa, as crianças podiam pular no sofá, fazer barulho e brincar de uma forma em que nas suas próprias casas não seria permitido. A "irresponsabilidade" da pesquisadora por não colocar limites nas crianças chegou ao ponto de uma vizinha fazer reclamações. Pires reflete a partir deste caso sobre os limites e possibilidades de ser adulta e pesquisar crianças:

“Consequentemente, isso colocava a própria possibilidade de realização da pesquisa em jogo. Precisava contar com a aprovação dos pais das crianças para que eles as deixassem em minha companhia. Para levar a cabo o meu trabalho, de um lado, era preciso aproximar-me das crianças e, até certo ponto, "fazer-me um" com elas; de outro, não poderia comportar-me excessivamente como criança, por correr o risco de perder a confiança de seus pais, comprometendo a própria pesquisa." (PIRES, 2007: 231)

A autora narra que adultas e crianças em Catingueira não interagem muito. Não é comum que compartilhem as mesmas conversas ou debatam opiniões. $\mathrm{Na}$ sua experiência de pesquisa, crianças e adultas formavam ontologias completamente distintas, o que lançava desafios para Pires, que não se encaixava na perspectiva corrente de ser adulta (PIRES, 2007). A autora falando somente de Catingueira é muito cautelosa e não universaliza a forte distinção entre crianças e adultos. $O$ fato de adultas e crianças serem concebidos de maneira distinta em Catingueira é um aspecto importante 
para a pesquisa com crianças lá.

A experiência no Canaã ensina não só sobre a importância de incorporar os adultos nas pesquisas com crianças, como para a importância de pesquisar as diferentes concepções de e formas de ser adulto. Adultos e crianças são produzidos um a partir do outro. Assim como Pires, muitos adultos no Canaã não caberiam no que se espera de um adulto em Catingueira. É uma concepção particular que entende que adultos não brincam, não vão para a escola, não fazem guerra de pipoca e não assistem desenhos animados. O que é ser adulto em determinado lugar não deveria também ser uma questão? O que é igualmente obliterado nas pesquisas que tomam esta concepção de adulto como universal?

Ariès (1981) argumenta que a infância moderna foi fruto de um processo histórico particular ocorrido na Europa ocidental. Com muita perspicácia, o autor vai mostrando como a concepção de infância foi mudando ao longo dos séculos na França, até chegar a ser uma fase separada do mundo dos adultos. A pesquisa de Ariès fortalece a antropologia da criança que refuta uma concepção universal de infância. Todavia, um viés pouco explorado na leitura do historiador diz respeito às transformações que a concepção de adulto também sofreu na Europa no mesmo período. Ariès não só diz que a escola foi se tornando o lócus da educação das crianças por excelência como também fala que os adultos foram deixando de frequentá-la ao longo destes séculos. Ariès não só diz que as brincadeiras foram cada vez mais consideradas próprias do mundo das crianças. Ele também diz que os jogos das adultas se diferenciaram das brincadeiras infantis, como vimos acima a propósito do dominó (p. 46)

A investigação das concepções de adulto podem afetar outras pesquisas para além da antropologia da criança. Não separar os fenômenos tidos como parte do "mundo das crianças" de fenômenos do "mundo das adultas" implica não separar as pesquisas com crianças das pesquisas sobre o Estado, Religião, Economia ou com os movimentos sociais. Sem abandonar a atenção para as vozes das crianças nas pesquisas, a discussão sobre as influências de diferentes concepções de adulto e de criança podem ser relevantes para muitos outros contextos de pesquisa. Movido por essas ideias, no próximo capítulo, discuto aproximações entre brincadeira e o Estado. Pela morosidade para marcar as parcelas do Canaã e soltar a portaria de assentamento, muitos militantes me disseram que o INCRA estava "de brincadeira". Resolvi seguir o caminho e investigar o que o INCRA estava fazendo no processo de regularização do assentamento do Canaã para encontrar em que convergia e em que não convergia com uma brincadeira de criança. 


\title{
CAPÍTULO IV \\ REFORMA AGRÁRIA NÃO É BRINCADEIRA
}

\author{
"Plunct Plact Zum \\ Não vai a lugar nenhum! \\ Tem que ser selado, registrado, carimbado \\ Avaliado, rotulado se quiser voar! \\ Se quiser voar.... \\ Pra Lua: a taxa é alta, \\ Pro Sol: identidade \\ Mas já pro seu foguete viajar pelo universo \\ É preciso meu carimbo dando o sim, \\ Sim, sim, sim." \\ (Carimbador Maluco - Raul Seixas)
}

\section{Eu não tô pra brincadeira!}

Na manhã do dia 16 de setembro, andei até a plenária. A assembleia estava marcada para as dez horas. Mesmo com o alerta de Dona Rita de que não começaria no horário, cheguei na plenária pontualmente para a assembleia. Ao lado da plenária, Laura e Tião estavam sentados no banco de eucalipto da vendinha reclamando da alta dos preços: gasolina, passagem de ônibus, restaurante comunitário. Chico estava em pé próximo aos dois. No meio da conversa, Eliana aparece para a assembleia:

Chico: Não tá fácil esse governo Rollemberg... - enquanto Eliana se aproxima.

Laura: Eliana! Vem aqui que a gente precisa trocar uma ideia urgente! Tão achando que eu sou moleque! - As duas se afastam da vendinha.

Chico: Ixi! No Canaã a gente sempre tem que ficar desconstruindo essas picuinha...

Tião me explica que as fofocas circulam rápido no Canaã. “Às vezes você tem uma conversa na portaria, dá nem uma hora outra pessoa tá sabendo mais da conversa que você. Capaz de eucalipto falar aqui. O povo fica sabendo de tudo" disse Tião.

Às onze horas, a assembleia ainda não tinha começado. Caetano chega na plenária. $\mathrm{O}$ menino estava de uniforme, com cabelo molhado do banho e de mãos dadas com sua mãe. $\mathrm{O}$ menino correu para a vendinha e pediu um saco de salgadinho para Tião. Tião perguntou para o menino como ele pagaria. Caetano respondeu a palavra mágica "fiado". Tião riu e entregou o 
salgadinho para o menino:

Tião: Esse menino já sabe comprar fiado.

Rita: Um perigo isso!

Chico: Vamos começar a plenária?

As pessoas foram para a plenária. Quando todos se acomodaram, começaram a rezar o painosso. Levei Caetano para a portaria para aguardar o ônibus da escola. Aguardamos alguns minutos e o ônibus chegou. Depois que o ônibus partiu, voltei para a plenária. As pessoas estavam terminando de cantar o hino. Chico, pela direção do movimento, foi o primeiro a falar. A apreensão era grande para saber quando os marcos das parcelas seriam colocados:

Chico: Pessoal, vou começar fazendo de novo um histórico aqui dos processos pra desconstruir as picuinha que aparecem. Naquela reunião que a gente fez no início de agosto, a gente formulou o Projeto de Assentamento, lembram? Aquela reunião foi muito boa. O cara do INCRA tava aqui, não foi Tião? Pois é. Depois daquilo, com o Projeto de Assentamento em mãos, a gente fez o mapa das parcelas que circulou na última reunião de coordenação, correto? Aquele mapa já tem o aval do ICMbio [Instituto Chico Mendes] e do INCRA.

Tião: Então o que tá faltando pra colocar esses marcos?

Chico: Calma Tião. To explicando! Depois que a gente fez aquele mapa, o infeliz do Luiz, lá do INCRA, tá falando que aquele mapa ainda não tá valendo. A gente ainda não sabe por que ele tá encrencando. Na outra reunião que tava só o Antônio e o cara do ICMBio eles disseram que tava tudo ok, que iam garantir a reserva legal externa ao assentamento e que só ia esperar o topógrafo voltar de férias para colocar os marcos com o GPS. Mas depois, parece que o Luiz encrencou. Por isso que tem essa reunião hoje lá no INCRA. Pra gente saber por que tão encrencando agora.

Alberto: A gente mesmo pega um GPS e coloca esses marcos aí!

Chico: Pois é, gente! É isso que to dizendo pra vocês. A conjuntura não tá boa. Esse ano mesmo o INCRA tirou dois acampamentos nosso: o Dorothy e o Marco Antônio. Eu acho que é melhor dar o passo firme. Criaram aí a fofoca de que o Chico não quer cair para as parcelas, que o Chico tá atrasando. Eu também tenho uma parcela pra ganhar! Quero cair lá tanto quanto vocês. Mas é melhor dar um passo firme de cada vez do que a gente colocar o carro na frente dos bois. Vamos lá no INCRA fazer pressão hoje e tentar sair com esses marcos pra semana que vem.

Tião: E depois a gente já cai para as parcelas!

Chico: É. Pra sair a Portaria de Assentamento, que é o último passo pra gente ganhar o título aqui 
das parcelas, ainda vai precisar anexar a Relação de Beneficiários [RB]. Aí a gente tem garantia mesmo. Mas se o movimento decidir cair pra dentro das parcelas quando marcar, é óbvio que eu vou junto. Acho melhor ir no passo firme. Mas quem manda é a base, né?

Eliana: Terminou sua fala, Chico?

Chico: Sim.

Eliana: Quem se inscreve?

Tião: Eu me inscrevo.

Eliana: Então vai lá.

Tião: Olha aqui gente. Ninguém aqui é criança. Vamos prestar atenção. O INCRA tá brincando com o pessoal. Mas eu não to pra brincadeira! Um dia diz que tá tudo certo, que o mapa tá certo. No outro, diz que nada tá garantido. Sem falar nos documentos para a RB que cada dia tem um a mais. Nós não é criança pra eles tarem brincando com nossa cara. E os dirigentes têm que tomar muito cuidado pra não cair nessa conversa mole do INCRA. Tá na cara que eles só quer nos enrolar. Acho que a gente tem que ir lá pressionar pra sair logo esses marco e quando colocar já cair pra dentro. Todo mundo aqui quer pegar essa chuva que vai vir.

Eliana: Agora sou eu. Eu concordo com o Tião nisso aí. Tá parecendo que o INCRA tá brincando com a gente mesmo, sabe? Quantos dias faz que eles disseram que ia sair essa RB? E os marcos que Alberto fez no dia seguinte que o Antônio disse pra nós que iam demarcar pra nós? Agora eles vem com essa cara lavada e diz que tem que esperar? Tamo a quanto tempo dizendo que vamos cair pra dentro dessas parcelas em poucas semanas? Já faz uns três mês. Mas, o Chico tem razão em uma coisa. Vai todo mundo lá hoje fazer pressão no INCRA? Nos últimos atos um pessoal que vem aqui, reclama, reclama, mas não faz nosso processo andar, não vai pra luta. Eu to vendo viu?

Na assembleia, a preocupação das militantes foi em relação ao retrocesso no processo que parecia se encaminhar para a demarcação. Em uma reunião em agosto com o INCRA e com o Instituto Chico Mendes (ICMBio), ficou acordado que o mapa mostrado na reunião de coordenação era válido e que as marcações das parcelas se dariam em breve. Assim, só faltaria a visita de um topógrafo com um GPS para delimitar exatamente até onde vai cada parcela. Porém, mesmo com a expectativa dos acampados, a demarcação não ocorreu. Com a frustração das expectativas em relação a demarcação, alguns conflitos e desconfianças entre militantes foram novamente atualizados.

Para Chico, esse atraso recupera as constantes "picuinhas" do Canaã. Comerford (2014), analisa o que chama de uma "sociabilidade agonística" e "conflitividade permanente" de um acampamento por reforma agrária. $\mathrm{O}$ autor argumenta que os eventos e conflitos inter ou 
intrafamiliares acabam por criar tensionamentos públicos e produzem consequencias na dinâmica política do movimento. Essa dinâmica agonística das “picuinhas”é potencializada pela grande circulação de informações entre os acampados. As narrativas e julgamentos morais sobre tudo que é observado dentro do acampamento (COMERFORD, 2014) - deslocamentos, tempos de visita, reuniões - fazem parte dessa sociabilidade agonística. Nas palavras de Tião sobre a conversa entre Laura e Eliana, "capaz de eucalipto falar aqui."

$\mathrm{Na}$ sua fala inicial, Chico tenta desconstruir as picuinhas dizendo que também está interessado em ganhar uma parcela. Argumenta que não quer atrasar o processo, mas tem receio do que o INCRA e o Governo de Brasília podem fazer caso o movimento pule etapas do processo de criação da Portaria de Assentamento. Chico diz que está igualmente preocupado com o processo. As falas de Tião e de Eliana resgatam a preocupação em relação ao processo do INCRA e afirmam categoricamente que não estão de brincadeira.

A recorrente fala incisiva sobre não brincar despertou a minha atenção. Por que em um espaço de assembleia a menção sobre brincadeira foi tão presente? Ao contrário das brincadeiras do segundo capítulo, as falas na assembleia fizeram questão de explicitar que "não estavam de brincadeira" e que o INCRA estava brincando com as pessoas do Canaã. Voltando às contribuições de Bateson, as brincadeiras envolvem mensagens metacomunicativas que precisam recorrentemente serem lembradas por quem brinca:

A distinção entre "brincar" e "não brincar", como a distinção entre "fantasiar" e "não fantasiar" é certamente uma função de processo secundário, ou de "ego". Dentro de um sonho, o sonhador está inconsciente que ele está sonhando, e dentro de uma brincadeira ele precisa se lembrar recorrentemente de que "isso é uma brincadeira ${ }^{29 "}$. (BATESON, 1972:321)

Em alguns momentos, na queimada ou nas outras brincadeiras, alguém esqueceu que estava em uma brincadeira e levou a sério demais, muitas vezes acabando em briga. Era importante, para que a brincadeira fluísse, que as pessoas soubessem brincar, não levassem a sério demais a brincadeira. Entretanto, em poucas horas ouvi mais "não estou de brincadeira" na assembleia do que "estamos brincando" nas brincadeiras. "Não estou de brincadeira" dito na assembleia também parece ser um frame, uma metacomunicação. Neste capítulo, parto dessa frase para analisar aproximações entre política e brincadeira.

29 Tradução livre: The discrimination between "play" and "nonplay", like the discrimination between fantasy and nonfantasy, is certainly a function of secondary process, or "ego". Within the dream the dreamer is usually unaware that he is dreaming, and within play he must often be reminded that "This is play". (BATESON, 1972:321) 


\section{Cada hora é uma coisa}

Esse frame, "não estou brincando", se repete na reunião daquela tarde no prédio do INCRA. Chegamos ao prédio por volta das 15:30. Por volta de 60 militantes do MST, crianças e adultos molares, se identificaram na secretaria e entraram em um auditório do prédio do INCRA. Dentro do auditório, em torno de cem cadeiras acolchoadas ficam de frente para uma mesa grande de madeira. A reunião estava marcada para as 16 horas. Às $16: 30$ a reunião ainda não havia começado. As pessoas começaram a cantar gritos de ordem. Às 17 horas, Luiz e Antônio, funcionários do INCRA, entraram no auditório e sentaram na mesa, em frente das pessoas:

Antônio: Desculpa o atraso, pessoal!

Alberto: Já tamo há quatro anos e uma hora atrasados! - As pessoas no auditório riem.

Luiz: Então vamos lá. Qual é a pauta de hoje?

Chico: Queremos falar hoje da situação do Canaã.

Luiz: Tá certo.

Chico: Então Luiz, a gente veio aqui tirar a limpo aquele negócio né? Na última reunião que a gente teve aqui, o Antônio passou pra gente aquele mapa, que a gente tá usando para marcar as parcelas. Até onde a gente ficou sabendo tava tudo certo e só precisava ir o cara com o GPS lá no Canaã fazer as marcações. A gente fez os marcos, tudo certo. Quando passou duas semanas e o cara não foi, a gente ligou pro Antônio, ele não atendeu. Aí a gente ligou pra você e você disse que o mapa não tava valendo ainda. Primeiro, a gente queria que fosse esclarecido isso. A outra é da RB (Relação de Beneficiários). A gente mandou aquela lista com as 69 famílias. Até hoje a RB não saiu e a gente precisa saber também como tá isso.

Luiz: Pronto?

Chico: Por enquanto é isso.

Luiz: Bom, retomando então. Depois que a gente fez o Projeto de Assentamento, com ajuda de vocês, a gente elaborou a proposta de mapa do assentamento com os limites da parcela, tudo bonitinho. A gente pensou junto a Área Comum do assentamento, vocês opinaram e a gente acabou fazendo esse número de parcelas porque vocês se comprometeram a fazer uma agrofloresta nas áreas mais sensíveis. Só que pro mapa ser aprovado, tem que ter Reserva Legal. Reforma Agrária não é brincadeira, pessoal. Vocês entendem do movimento e meu dever aqui é entender da lei. Eu posso ser simpatizante do movimento, mas a minha atribuição é fazer valer a lei. Não posso regularizar um assentamento sem uma reserva legal...

Chico: Mas a gente fez a reunião com o cara do ICMBio e ele garantiu uma Reserva Legal externa à 
área do Canaã, não foi?

Luiz: Foi. Mas eu não posso validar nada de boca. Eu preciso ainda que ele me dê algum documento comprovando isso. Essa semana o Dr. Ricardo, do Instituto Chico Mendes, tá em uma viagem e na próxima semana a gente fecha isso. Mas não pode demarcar nada enquanto eu não tenho algum documento que me dê essa garantia, entendeu? Outra coisa, vocês sabem as condições que a gente trabalha aqui. No momento a gente tá com dificuldade de arranjar um topógrafo pra demarcar lá.

Chico: Isso a gente já tinha conversado. A gente tem como arranjar um GPS e uma pessoa especializada por conta do movimento. Se fizer assim, vale pra vocês?

Luiz: Vale, claro! - Luiz dá um gole no copo de água em sua frente e pergunta - Antônio, quer complementar alguma coisa?

Antônio: Não, é isso. Estamos aguardando a volta do Dr. Ricardo. Temos uma reunião marcada para quarta feira que vem.

Chico: Quarta-feira?

Antônio: É.

Luiz: Em relação à $\mathrm{RB}$, a gente tem um conjunto de documentos que tem que reunir de cada um de vocês. A política da Reforma Agrária tem um público-alvo. Tem que ser respeitado. Não pode ser servidor público, não pode ganhar mais de três salários-mínimos, não pode ser aposentado, não pode ter empresa em seu nome... Então a gente tem que confirmar isso com os outros órgãos. $\mathrm{O}$ MST é parceiro nosso e faz uma lista, que é legítima do movimento. Mas a lei depois seleciona quem está dentro da política e quem não tá.

Rita: Mas e se eu tiver alguma coisa no meu nome que eu nem to sabendo?

Luiz: Não vai ter, senhora. E mesmo assim, depois que a gente detectar alguma irregularidade que impeça a pessoa de ser beneficiária da política, a gente tem um prazo de quinze dias pra você conseguir regularizar. Sem problema.

Tião: E quais são os documentos que falta ainda? Porque cada hora é uma coisa. Vem aqui e tá faltando ver sei lá mais o que. Diz pra gente tudo que falta aí pra RB.

Luiz: Então vou falar. Tão anotando aí? Olha, falta um documento do INSS, da SEAGRI (Secretaria de Agricultura e Desenvolvimento Rural do Distrito Federal), da Secretaria de Administração Pública pra gente saber se vocês são funcionário público e da Secretaria de Segurança Pública.

Tião: Depois disso tem mais nada, né?

Luiz: É. Depois desses documentos, a gente vai fazer a Relação de Beneficiários, o pessoal que não for contemplado vai ter quinze dias pra regularizar a sua situação. Aí a gente anexa com o mapa do Projeto de Assentamento, faz a Portaria e a terra de vocês tá garantida. 
Tião: E esse ano a gente cai pras parcela ainda?

Luiz: Pretendemos que sim.

Eliana: Mas é esse ano?

Luiz: Sua fé é fraca assim? - em tom de brincadeira - Alguém tem mais alguma coisa pra falar?

Eliana: Eu quero!

Luiz: Diga.

Eliana: Luiz. É muito sofrido pra nós essa indecisão. Um dia fala uma coisa, no outro já tá faltando outra. A gente fica achando que vocês tão de brincadeira com a gente. Enquanto isso, já vai outro ano, daqui a pouco começa a chuva de novo e nada da gente ir pra parcela. Se o que tá faltando são esses documentos tudo bem, mas não vamos atrasar o processo depois que conseguir tudo. Outra coisa, aqueles eucaliptos... Tinha ficado combinado da empresa tirar primeiro os eucaliptos que não ficam perto do acampamento, pra depois tirar perto dos barracos. Ainda tem um tanto de eucalipto longe e todo dia eles tiram uns eucaliptos pertinho. Tá todo mundo aqui com medo de perder barraco, perder até filho com um eucalipto daquele caindo. Se ainda tem um tempo até a gente ir pras parcela, como vai fazer com os eucaliptos?

Antônio: Pessoal, em relação aos eucaliptos nós já conversamos né? Não somos nós que decidimos sobre a retirada dos eucaliptos. Eles pertencem agora a uma empresa e o máximo que a gente conseguiu foi fazer esse acordo de tirar os eucaliptos de longe antes. O próprio Luiz já sugeriu pra vocês mudarem o acampamento de lugar para a empresa tirar o resto dos eucaliptos e vocês que não quiseram.

A sensação é de que pouca coisa avançou no processo com a reunião. A expectativa de uma demarcação das terras a um curto prazo foi desfeita. Não se tinha mais certeza de uma Reserva Legal garantida pelo Instituto Chico Mendes. Na reunião, Luiz informou os documentos que ainda faltam para a Relação de Beneficiários. No entanto, a despeito do que falam os funcionários, as militantes nunca tem a certeza de que os documentos informados são tudo que de fato falta para o processo. Como disse Tião: "Cada hora é uma coisa". E mesmo em um ambiente burocrático, as insinuações sobre brincadeiras persistiram.

Schwartzman (1978) diz que a brincadeira sempre foi entendida no ocidente como o oposto do que é considerado sério e produtivo. Fians (2015) também aponta para uma oposição entre "de brincadeirinha" e "sério" com as crianças da educação infantil. O enquadramento das falas tanto na assembleia quanto na reunião com o INCRA parecem apontar para o mesmo sentido da oposição entre o que é sério e o que é brincadeira. Tião queria ser levado a sério. Eliana queria que as palavras que proferia fossem entendidas exatamente como denotam. Luiz quer comunicar que o seu 
trabalho é produtivo e sério quando diz que "reforma agrária não é brincadeira". O desejo de entrar em uma parcela não poderia ser confundido com uma ideia fantasiosa e infantil.

A metacomunicação envolvida na mensagem "não estou de brincadeira" parece ter ligação com essa oposição entre o que o sério e o de brincadeira. No entanto, acredito que essa mensagem pode dizer ainda mais sobre as duas reuniões. Se Luiz precisa negar que a reforma agrária é brincadeira, é porque é possível confundi-la com uma. Se oposição entre uma reunião burocrática e uma brincadeira precisam ser o tempo todo evidenciadas é porque devem ter alguma semelhança. Que semelhanças seriam essas?

A primeira semelhança é linguística. A mensagem "Isso é uma brincadeira" carrega invariavelmente uma instabilidade na comunicação pois falseia os próprios signos utilizados na mensagem (BATESON, 1972). Se um menino diz "Eu sou um gigante de brincadeira", a frase carrega uma ambiguidade, pois se é de brincadeira ele não é um gigante e se ele é um gigante não pode ser de brincadeira. Essa ambiguidade é semelhante ao que Herzfeld (1993) vai dizer sobre a linguagem nos processos democráticos. Para o autor, a linguagem utilizada pela burocracia estatal tem uma aparente transparência. Apesar da tentativa dos funcionários de mostrar que a lei e que os processos seguem ordens genuinamente transparentes, a linguagem pode se fazer "semanticamente obscura” e permitir “desviar atenção do caráter contingente de seu uso 30"(HERZFELD, 1993: 115).

Com a experiência cotidiana de lidar com uma linguagem que se apresenta como transparente, mas que se mostra obscurantista, a fala "Depois desses documentos, a gente vai fazer a Relação de Beneficiários" apresenta uma ambiguidade. Depois de tantas vezes indo ao INCRA, a expectativa de um processo que aparentemente logo se resolveria foi frustrada. A aparência de uma linguagem transparente dá lugar a uma indagação: Tão brincando comigo? Esse sujeito fala como $s e$ fosse demarcar a terra, mas não demarca. Será que eu não percebi que isso é uma brincadeira desde o início? Assim, na convivência com processos morosos, burocratas e militantes afirmam o tempo todo que não se trata de uma brincadeira. É a resposta metacomunicativa que tem que ser rememorada todo o tempo diante da dúvida em relação a uma linguagem que se pretende transparente, e, no entanto, é instável. Tanto brincadeira quanto a burocracia produzem mensagens que geram ambiguidades.

Além da semelhança linguística, brincadeira e burocracia possuem semelhanças em relação à repetição e ao controle do tempo. A reunião com o INCRA de que participei não foi a primeira a que as acampadas foram e nem a última. A dinâmica repetitiva, como em um ritual, é característica dessas reuniões em órgãos públicos. Herzfeld (1993) argumenta que esta obsessiva repetição é um

30 Tradução livre: Even thought its outer form may be quite simple, language can be made semantically obscure in order to allow bureaucratic actors to deflect attention away from the actually quite contigent character of its use. (1993:115) 
elemento que possibilita o controle do tempo do cliente pelo burocrata:

"Primeiro, o tédio absoluto de constantemente ter que "voltar semana que vem" amortece o senso da velocidade do tempo para qualquer um, principalmente nessa repetitividade. Segundo, a habilidade de demandar esse nível de obediência expressa o controle que os burocratas têm do tempo dos clientes, fazendo os últimos irrelevantes por comparação: Não consegue ver que estou ocupado $^{31}$ ?" (HERZFELD, 1993: 162)

Assim que Luiz entrou na sala, Tião brinca que o funcionário do INCRA estava atrasado em quatro anos e uma hora. A sensação de que estão todos perdendo tempo naquela reunião é geral. As militantes teriam que voltar na semana seguinte, que é quando o Dr. Ricardo, do ICMBio voltaria de viagem. Eliana chama atenção para mais uma chuva que vem e as pessoas ainda não estão na parcela. As reuniões repetitivas e os sempre faltantes documentos alongam o tempo que inicialmente os militantes esperavam. "A gente cai pras parcela esse ano ainda?" indaga Tião. Benjamin (2009), encontra no mesmo princípio de repetição a essência para o jogo das crianças.

"Um tal estudo teria, por fim, de examinar a grande lei que, acima de todas as regras e ritmos particulares rege a totalidade do mundo dos jogos: a lei da repetição. Sabemos que para a criança ela é a alma do jogo; que nada a torna mais feliz do que o "mais uma vez". (...) E, de fato, toda e qualquer experiência mais profunda deseja insaciavelmente, até o final de todas as coisas, repetição e retorno, restabelecimento da situação primordial da qual ela tomou o impulso inicial." (BENJAMIN, 2009: 101 e 102)

Ambos, jogo e burocracia, são obsessivamente repetitivos. Porém, enquanto princípio da repetição do jogo é o prazer, a repetição dos processos morosos do Estado são tediosos. Os processos burocráticos e os jogos parecem criar um tempo próprio, autônomo. O tempo para assentar o Canaã não coincide com o tempo necessário para o plantio: tempo de semear, tempo de chuva, tempo de plantar milho, etc. Da mesma forma que sempre existe uma partida no jogo, tem sempre como brincar mais um pouco, independente se está na hora do banho ou do almoço.

Este tempo não é só de tédio de repetitivas reuniões. É também tempo de privação e sofrimento. Borges (2004) apresenta o tempo de residência no Distrito Federal como um critério

31 Tradução Livre: First, the sheer tedium of constantly having to "come back next week" deadens one's sense of the passage of time, especially in its repetitiouness. Second, the ability to demand this level of obedience express the bureaucrats control over the client's time, making the latter unimportante by comparison: Can't you see I'm very busy? (HERZFELD, 1993: 162) 
importante para o acesso às políticas públicas de moradia no Recanto das Emas. Este tempo de privação e de sofrimento, controlado pelo Estado, é um pré-requisito no atendimento de demandas por moradia ou por terra também em suas pesquisas na África do Sul. "Um tempo que demonstre o quanto estiveram batendo à porta de um Estado que habitualmente não escuta as pessoas justamente porque elas são transitórias, mas que ainda assim, em alguns momentos, abre uma fresta [...]" (BORGES, 2014: 32) No Canaã, o usufruto pleno da terra dentro da parcela também teve que ser conquistado por meio de um tempo de sofrimento no acampamento, sem água e no meio de eucaliptos que ameaçam cair. No caso, a expectativa em relação ao tempo de sofrimento que ainda está por vir se comprime e se expande de acordo com o andamento dos processos do INCRA. Ora a marcação das parcelas parece iminente. Ora, o que parecia ter avançado no processo anteriormente regride, e o tempo de privação para alcançar a parcela volta a se expandir novamente.

Quem já tentou interromper uma criança na hora do banho sabe que, assim como o Estado, o tempo da brincadeira submete todas as outras atividades. Quem brinca corre, foge e se esconde prazerosamente de quem está levando tudo a sério e quer interromper a brincadeira. Existe um monopólio do tempo gerado pela brincadeira e pelo Estado. É aborrecedor lidar com quem está de brincadeira quando não se participa efetivamente dela. Quem lida com o Estado também pode se aborrecer se o processo parece não avançar, ou nas palavras de Tião, se "cada hora é uma coisa". Só podem estar de brincadeira.

Podemos fazer um paralelo entre o trabalho de precipitar o tempo da burocrata e do homem do tempo da televisão estadunidense, descrito por Wagner (2009). Para o autor, a missão de prever o tempo possui um grande obstáculo: o tempo é imprevisível. Apesar disso, o homem do tempo, com as suas previsões, molda as expectativas das pessoas, fazendo-as se preparar para a chuva ou para a ausência dela no cotidiano. Como esta profissão consiste em invariavelmente falhar de vez em quando, os homens do tempo dos Estados Unidos - no Brasil não noto essa tradição - na tentativa de não serem levados tão a sério por seus telespectadores fazem gracinhas, brincam (WAGNER, 2009). Nas suas também invariáveis falhas, os burocratas igualmente criam expectativas sobre o tempo que levam os processos e fazem as pessoas se precipitarem a ele. No entanto, ao contrário do homem do tempo, os burocratas não são famosos por tentarem fazer gracinhas e brincadeiras de propósito. Tudo que se espera de um burocrata é que ele não esteja de gracinha e sim levando a sério o seu trabalho.

$\mathrm{Na}$ epígrafe dessa dissertação, trago uma frase de Nietzsche que diz que a maturidade chega ao encarar a vida com a mesma seriedade que uma criança encara uma brincadeira. Acredito que essa frase exprime bem a maneira como a militância do Canaã entende o trabalho sério, na ótica do burocrata. Encarar a brincadeira com a seriedade de uma criança, o saber-brincar descrito no 
capítulo II, é não levá-la excessivamente a sério ao ponto de acreditar que todas as suas possibilidades estão inscritas nas regras e, simultaneamente, não falsear todas as suas expressões e efeitos por se tratar apenas de uma brincadeira. É nesta seriedade irreverente e brincante que as pessoas do Canaã encaram o trabalho da burocracia.

\section{No campo adversário}

No mês de novembro, eu já tinha iniciado o processo de escrita da dissertação quando voltei novamente ao Canaã em um domingo de manhã. As pessoas se aglomeravam na plenária. Naquele dia, iriam fazer o sorteio das parcelas. Com a chuva, o tom vermelho sangue da terra seca deu lugar a uma tonalidade mais escura. O clima era de festa. Finalmente a hora de cair para as parcelas estava a um passo de se concretizar.

As militantes rezaram o pai-nosso e cantaram várias músicas do movimento puxadas por Eliana. Algumas militantes fizeram falas emocionadas relembrando a luta do acampamento. Chico chorou ao citar quatro nomes de companheiros que morreram durante o acampamento, um deles, o pastor. Relembrou que o sorteio das parcelas consagrava a luta daquelas pessoas também. Dora, uma militante de outro acampamento, fez a seguinte fala:

“Quando um companheiro vibra por chegar na sua terra, a gente vibra junto. Tô muito feliz de tá aqui hoje. Um tanto de gente que vi sofrendo aqui dentro, que foi ocupar os órgão lá no plano comigo e que hoje tá feliz de ir pra sua parcela. Mas peço pra vocês uma coisa. Não esqueçam de quem lutou ao lado de vocês. A terra a gente conquista com a nossa luta e com a luta de outras pessoas também. A gente sabe que tem muita gente que depois que entra nas parcelas não quer saber mais de movimento. Mas temos bons exemplos também de gente que anos depois de ser assentado tá com a gente. Eu quero que vocês sejam muito felizes. Mas não esqueçam de quem ainda tá acampado não. A nossa luta é por reforma agrária."

As falas de Dora e de Chico remetiam à ideia de luta que ultrapassa as barreiras do indivíduo, como na luta da família descrita no capítulo I. Na hora da conquista, Dora lembrou que a luta foi de diversas famílias que não podem ser esquecidas quando se consegue uma parcela. A luta da família era o critério para alcançar o nome na lista do movimento. Agora que iriam para as parcelas, a conquista do pedaço de terra não remetia à luta só daquela família.

Enquanto outras pessoas falavam, perguntei diretamente para o Chico se a RB tinha saído. 
Chico responde que não e que tava todo mundo ali ciente disso. "Não sou eu que vou frear, né?" disse Chico. Depois que as falas acabaram, as pessoas organizaram o sorteio. Foram escritos todos os nomes dos contemplados e foram colocados em uma urna. Em um globo de bingo estavam bolas com números - de um a sessenta e nove - ou seja, o mesmo número de inscritos. "Tem que ver uma criança para fazer o sorteio!” disse Eliana. Caetano, Victor e Cleonice foram para perto do globo. A ansiedade e empolgação tomavam conta da plenária. Caetano tirou o primeiro nome da urna.

\section{Eliana: Tião!}

Tião: Eta que é agora! - Victor rodou o globo do bingo. Cleonice pegou uma bola. Eliana: 48 !

Tião exclamou e foi direto olhar no mapa a parcela correspondente ao número 48. Para cada nome tirado por Caetano, Victor e Cleonice sortearam um número correspondente. A brincadeira dava fim a agonia de tantos anos querendo um pedaço de chão. Saí logo depois do sorteio. Dona Rita me disse depois, por Whatsupp, que a comemoração durou até tarde. Ela foi sorteada com uma parcela perto do córrego.

Se de um lado a brincadeira do INCRA cansa, o sorteio das parcelas anima as famílias. A brincadeira com a urna e as bolinhas de bingo definiu para quem iria cada uma das parcelas divididas no mapa e marcadas no território. A diversão das famílias no momento do sorteio não esvazia o sentido político daquele sorteio. Após anos de luta com o INCRA, o acampamento Canaã tornou-se um assentamento. O INCRA ainda não havia liberado a Relação de Beneficiários. A portaria de assentamento do Canaã não tinha saído mesmo com as marcações feitas na terra com aval do próprio INCRA. O sorteio era ao mesmo tempo a consagração da luta dos últimos anos e uma decisão em relação ao usufruto da terra para o próximo período. Arriscada, mas nem por isso, menos divertida.

O sorteio não foi a única brincadeira que decidiu sobre o futuro das famílias nas parcelas do Canaã. Nos últimos cinco anos, as famílias pontuavam todas as vezes que participavam de um ato, cumpriam uma tarefa ou iam a uma ocupação de terra ou de órgão. O ranking de pontos dessa gincana de longa duração estabeleceu quem iria e quem não iria para a terra. Esse papel de estabelecer decisões jurídicas e políticas é também intermediado por jogos e brincadeiras em outros contextos. Huizinga (2000) conta por exemplo que quando um esquimó possui alguma queixa, as competições de tambor são a maneira de dar algum tipo de resolução a ela. Nenhuma outra forma de jurisdição acompanha as decisões feitas a partir destes concursos (HUIZINGA, 2000). Huizinga compara a ludicidade dos concursos de tambor que se desenrolam em decisões judiciais a sessões 
satíricas e cômicas que puniam crimes de menor espécie em tribunais rurais de países germânicos ${ }^{32}$.

O sorteio usado para distribuir as parcelas da terra contrastava com o jogo da burocracia no INCRA. O sorteio acelerou o processo de distribuição das terras de forma ilegítima para o INCRA. A diversão, os risos e a alegria contrastavam com as reuniões exaustivas e repetitivas feitas no prédio. O sorteio inscreveu na terra de uma vez os nomes de quem alcançara a contemplação. $\mathrm{O}$ mapa feito com o INCRA, que ameaçava se realizar e também ameaçava não se realizar, deixou marcas no território não só na forma de retângulos de cinco hectares medidos com ajuda de um GPS. Agora, essas marcações ganhavam um nome sorteado. Esses nomes não foram para o Diário Oficial, logo não constam nos autos. No entanto, Dona Rita já sabia onde vai poder plantar por enquanto. Tião o mesmo. O sorteio dessas porções métricas de terra desfez o impasse de não poder plantar na estação chuvosa. Ao mesmo tempo, o sorteio criou outras questões para as moradoras do Canaã: Como o INCRA vai reagir? Vão tentar tirar as famílias? Essa parcela que agora é minha assim será por quanto tempo? Qual será a próxima jogada?

Ironicamente, esses efeitos mútuos entre o mapa e o território remontam à discussão que Bateson (1972) faz de relações mapa-território ${ }^{33}$. Digo ironicamente pois os fenômenos da linguagem sob esta insígnia vão muito além de relações entre territórios e mapas. Assim como os mapas não são a mesma coisa que um território, os nomes não são a mesma coisa que são por eles nomeados. O interessante é que, para Bateson, a comunicação humana consegue operar em diferentes níveis de abstração. Enquanto determinados registros, as mensagens não fazem a discriminação entre os nomes e o que eles denotam, em mensagens metalinguísticas esta discriminação é feita. $\mathrm{O}$ autor utiliza um exemplo simples para explicar essa distinção. Na frase "O gato está no tapete", a mensagem é denotativa. Quando se diz “A palavra gato não pode arranhar”, a linguagem estabelece um outro nível de abstração que discrimina a palavra gato do que ela denota. Há ainda uma terceira forma de comunicação:

Daí resulta que o jogo aqui é usado como um princípio explicativo que implica em uma combinação de processos primários e secundários. Isso, no entanto, está relacionado com o que eu disse anteriormente, quando argumentei que a brincadeira marca um passo na evolução da comunicação o passo crucial na descoberta das relações mapa-território. Em processos primários, mapa e

32 "Trata-se aqui, portanto, de um costume cultural que desempenha a função judicial sob uma forma perfeitamente agonística, sem contudo deixar de constituir um jogo no sentido mais próprio do termo. Tudo decorre no meio de risos e da maior alegria, porque o que mais importa é conseguir divertir o público.” (HUIZINGA, 2000: 66)

33 Map-territory relations (BATESON, 1972 
território são equivalentes; em processos secundários eles podem ser discriminados. Na brincadeira, eles são tanto equivalentes quando discriminados ${ }^{34}$. (BATESON, 1972: 321)

O mapa das parcelas de terra feitos com base no território do Canaã não é a mesma coisa que o Canaã. Ele foi construído para que no futuro o Canaã pudesse se desenhar enquanto assentamento como está no mapa. No entanto, para o INCRA o mapa não está pronto. Mesmo assim, as famílias fizeram um sorteio das terras com base no mapa. Este jogo, em que ora o mapa se realiza em território ora ele se distingue deste território, tem a estrutura da comunicação da brincadeira. O sorteio das parcelas feito por crianças não só decidiu onde cada um iria plantar como inscreveu na terra mais um passo para que ela se parecesse mais com aquele mapa. Deu mais um passo no jogo contra a paralisação dos processos do Projeto de Assentamento. Mais um passo para que o sonho da parcela se tornasse realidade. A queimada, o pique cola e o tourinho produziam espaços na medida que a brincadeira acontecia. Os limites, os locais para onde se corria e para onde não se corria, as linhas que dividiam o campo do time adversário. As brincadeiras inscreveram na terra limites frágeis e instáveis. A brincadeira do INCRA e do MST também produziram espaços e limites na terra.

\section{O Estado guardando caixão? O movimento é café-com-leite?}

Nas semanas seguintes de novembro e dezembro, as famílias do Canaã se espalharam pela terra. Seguindo o mapa elaborado junto ao INCRA, as famílias ocuparam as parcelas que lhes couberam pelo sorteio. Nos hectares antes ocupados por monoculturas de eucaliptos, ergueram-se novos barracos. A militância plantou mais feijão, mais abóbora e seguiram ocupando. O movimento desfez e esvaziou o acampamento e os eucaliptos que restavam na terra puderam ser retirados sem cair no barraco de ninguém. Com bem menos eucaliptos agora que há cinco anos quando a ocupação começou, sobra mais água da chuva para os córregos e para os lençóis freáticos. Mesmo assim a relação de beneficiários do INCRA ainda não tinha saído e a portaria que legaliza a distribuição dessas terras ainda não fora publicada.

A resposta do INCRA veio com o pedido de saída dos militantes das terras. O apelo do INCRA foi novamente o cumprimento da lei. A ocupação das parcelas de 5 hectares, de acordo com

34 Tradução livre: It therefore follows that the play frame as here used as an explanatory principle implies a special combination of primary and secondary processes. This, however, is related to what was said earlier, when it was argued that play marks a step forward in the evolution of communication - the crucial step in the discovery of mapterritory relations. In primary process, map and territory are equated; in secondary process, they can be discriminated. In play, they are both equated and discriminated. 
o mapa elaborado junto ao órgão, é retratada em uma reportagem ${ }^{35}$ veiculada no final de novembro pelo DFTV. A reportagem, que simplesmente ignorou o histórico de ocupação da terra pelo MST, aborda a preocupação com a preservação do meio ambiente e das nascentes de água que alimentam o córrego do Rodeador. Para quem sabe que o histórico da terra, a reportagem soa como brincadeira. A ênfase no cumprimento das leis é bem evidente na entrevista de um servidor do INCRA. Ele diz que "A forma como fizeram é contra o INCRA, contra a lei. Não permitimos isso. Não admitimos. Sempre negociamos com as lideranças desse movimento social que deveriam aguardar o término dos trabalhos, dos estudos técnicos para que pudéssemos, então, conceber aquilo como assentamento."

A relação do INCRA com a lei, seja levando-a muito a sério ou adaptando-a de acordo com a situação, lembra a discussão das regras nas brincadeiras no capítulo II. Em alguns momentos, as regras eram levadas a sério demais, levando a brigas ou a exclusão de quem não as sabia, como no dominó. Em outros momentos, as regras eram suspensas por alguns instantes em favor da brincadeira, por exemplo na queimada, quando os café-com-leite participam mesmo quando isso significa abdicar de vencer. Essa relação ambígua com as regras, suspendendo-as e exaltando-as, é comum à brincadeira e à burocracia.

O INCRA age como quem leva a sério demais a brincadeira ao enfatizar tanto o domínio da lei e das regras. Paralisa todos os processos porque as regras não estão sendo cumpridas. Esquece-se que trata-se de uma brincadeira e, como na esquizofrenia, não reconhece a natureza metafórica de sua fantasia (BATESON, 1972). O interessante é que quanto mais leva a sério suas leis, protocolos e formulários, mais o tempo da brincadeira se alonga. Quanto mais pedante é o INCRA com as regras, mais tempo as famílias passam pela privação, em reuniões repetitivas. A flexibilização das regras é inconcebível em favor dos movimentos sociais.

Ao mesmo tempo, as regras mudam o tempo todo, mesmo que os burocratas digam que não. Ao lidar cotidianamente com o INCRA, os militantes do MST notaram que a cada momento as regras pareciam indicar uma coisa diferente. Em determinado momento tinham acordado de ter a Reserva Legal fora do assentamento, em outro momento isso não era mais possível. Sempre um novo documento poderia ser adicionado para que a Relação de Beneficiários saísse. Como em uma brincadeira, a burocracia muda as regras o tempo todo. O problema é que o movimento não está pra brincadeira.

No pique-cola americano, quando o pego ficava perto demais de quem estava colado, as crianças diziam que o pego estava "guardando caixão", para que a brincadeira continuasse a fluir.

$35<$ http://g1.globo.com/distrito-federal/videos/t/todos-os-videos/v/incra-vai-pedir-saida-de-invasores-em-terreno-debrazlandia/4634062/> 
Ao contrário do que as burocratas querem atribuir às leis do Estado, a regra de não poder "guardar caixão" era evocada de acordo com situação. Não existia uma regra combinada anteriormente que definia uma distância mínima. A regra era evocada quando quem brincava notava que o fluxo da brincadeira se interrompia. Voltando a nomenclatura do capítulo II, é possível dizer que as leis pretendem ser sérias como regras-contorno, mas como em uma brincadeira, na prática, são regrastensão. Entretanto, ao contrário do pique cola americano, as regras não mudam de situação em situação para que as coisas fluam e as pessoas continuem se movimentando. A cada momento as regras mudam para que o processo continue paralisado. O INCRA sempre inventa uma forma de ficar guardando caixão.

Não a toa a Teoria dos Jogos, desenvolvida inicialmente entre os matemáticos e lógicos, foi tão popular na Ciência Política (FEREJOHN \& PASQUINO, 2001). Nos modelos estudados pelo acoplamento da Teoria dos Jogos e da Escolha Racional, a maximização dos próprios interesses explica as motivações dos atores políticos cooperarem, traírem uns aos outros, fazerem acordos, escolherem plataformas, blefarem, etc. Os jogos possuem incentivos e prejuízos, ganhadores e perdedores, prêmios e castigos que vão se delineando de acordo com o acúmulo de jogadas dos jogadores (SOUZA, 2003). Entretanto, para essas teorias, os jogos prescindem de regras que orientam as escolhas e estratégias dos jogadores, e todos seus jogadores têm que estar submetidos a elas para que a teoria funcione (SOUZA, 2003; CÔRTES,1999).

Tomando desejos, preferências e crenças como dados, e assumindo que as regras são relativamente estáveis e conhecidas, é fácil reduzir a ação política a um conjunto de estratégias para alcançar um objetivo ou a maximização dos próprios interesses. Da mesma forma que o INCRA, a Ciência Política leva a sério as instituições e as regras. Acontece que quando se sabe brincar, as regras mudam e podem ser, inclusive, suspensas. Os jogos que possuem regras e estratégias não são universais. São particulares, se é que existem. Os jogos e modelos usados na análise de cientistas políticos não admitem esses instantes de suspensão das regras e da necessidade de haver ganhadores e perdedores. É possível aventar a existência de uma ação política que escapa da razão instrumental e borra o limiar entre as sérias jogadas políticas e as brincadeiras.

A expressão de uma ideia de política que não concebe a suspensão das próprias regras e da razão instrumental é a sistemática exclusão nesta brincadeira. Da mesma forma que Caetano não pode participar do jogo de dominó por ser uma criança pequena, a participação política é restrita a quem domina as regras. As regras estáticas e pré-definidas jamais são suspensas para a plena participação de quem não se adéqua a elas. No máximo, são substituídas por novas regras rígidas formuladas em um novo contrato social, que novamente nunca é suspenso, vale em todas as situações dali em diante. Voltamos a comparação entre um jogo de futebol profissional e a roda de 
capoeira feita por Bispo (2015), "uma pessoa de qualquer sexo e de qualquer idade que não conheça nenhuma das duas modalidades tem muito mais probabilidade de ser convidada para entrar numa roda de capoeira que num jogo de futebol.” (BISPO, 2015: 42).

Mesmo com todas essas limitações para a participação dos movimentos na brincadeira do INCRA - e do Estado - é exaltada a participação nas decisões. O MST “ajuda a fazer o mapa” com o INCRA. A sociedade civil participa das decisões nos conselhos e nas conferências. O orçamento é participativo. Seriam os movimentos sociais os café-com-leite da democracia liberal? Por um lado, permanece o mesmo olhar condescendente que o irmão mais novo detesta receber do mais velho: A gente deixa você participar, mesmo você não sendo capaz de nos vencer.

Existe também uma diferença importante entre a participação dos movimentos sociais e dos café-com-leite. As crianças menores não são chamadas para participar no momento de combinar as regras - até porque este momento não existiu nas brincadeiras que participei. A participação ocorreu durante o jogo. Com a necessária suspensão das regras. Quando Caetano era café-com-leite, o menino brincava simultaneamente de diferentes brincadeiras sem os prejuízos dos demais. Podia cruzar a linha do campo adversário sem grandes consequências. Brincava de encher de terra uma garrafa e nem por isso virava o alvo mais fácil. Para que todos pudessem participar, foi necessário não levar as regras tão a sério. Saber brincar envolvia uma postura anti-instrumental de aceitar o café-com-leite entre os jogadores.

A participação dos movimentos sociais nos processos decisórios do Estado e dos café-comleite nas brincadeiras têm particularidades. Nas brincadeiras no acampamento e na praça, não aconteceram momentos anteriores para acordar as regras. Mesmo que na maior parte das vezes sejam simplesmente ignorados, a contribuição dos movimentos sociais é feita - nos conselhos e nas conferências por exemplo - no processo decisório. (SOUZA, 2008) A participação dos café-comleite na brincadeira ocorria quando as crianças maiores abdicavam de vencer. Não era uma participação nas decisões, nas regras e sim uma possibilidade de desfrutar da brincadeira. Uma participação análoga dos movimentos sociais seria de poder desfrutar da terra, mesmo que para isso se flexibilizasse as leis. Como isso é inconcebível no âmbito jurídico e político, as militantes do MST ocupam a terra

\section{Política e brincadeira}

No clássico do cinema A Vida é Bela (1997), o judeu Guido encontra uma maneira criativa de não assustar seu filho Giosué após serem capturados pelo exército nazista e serem levados a um 
campo de concentração. Ele conta para o filho que o campo de concentração, na verdade, consistia em uma grande brincadeira. O objetivo dessa brincadeira era de acumular mil pontos. A criança que conseguisse este feito primeiro levaria para casa um tanque de guerra. As ordens dos soldados nazistas eram as regras do jogo. Ficar com medo, chorar e querer ver a mamãe implicavam em perda de pontos. Esconder-se dos soldados rendia pontos ao pequeno Giosué. Ao longo do filme, o pai vai apresentando tudo ao redor como parte desse jogo e lembrando seu filho, o tempo todo, que aquilo se tratava de uma brincadeira.

O filme mostra que mesmo a face mais terrível de um Estado genocida pode ser encarada como uma brincadeira - de muito mal gosto, é possível acrescentar. Tempo de privação em um campo de concentração - sem comida, dormindo em um lugar extremamente desconfortável, sem a mãe - pode ser parte de um jogo aos olhos de uma criança. Morar entre eucaliptos, com privações de todo tipo, para no final ganhar um pedaço de terra também pode ser facilmente confundido com uma brincadeira, ainda mais quando o Estado cria uma série de obstáculos para que este processo se arraste ao máximo de tempo e não chegue ao fim. Durante a privação, os militantes lembram o tempo todo que não estão para brincadeira. O Estado responde "Também não estou para brincadeira. Tenho leis, processos, protocolos a seguir" e as regras seguem intactas, as privações continuam.

O que chama atenção nessa comparação entre brincadeira e Estado é a oposição que é insistentemente colocada entre as duas coisas. Parece que admitir que o Estado brinca com os prazos invalida qualquer possibilidade de crença nele. Quando os funcionários dizem que "não estão brincando", eles dizem que estão sob o registro do que pede a lei e do que pede o Estado. A brincadeira não pode ser levada tão a sério, enquanto que o Estado só pode ser levado a sério. Pilhas de leis, registros, sistemas e dados são produzidos diariamente por um Estado que não está para brincadeira, e quer saber exatamente como as coisas são. Como óleo e água que não se misturam, a linguagem do Estado não quer ser confundida com uma mera brincadeira. Quanto mais o Estado esforça-se para não ser uma brincadeira e segue suas leis e protocolos, mais obstáculos aparecem na vida das pessoas e mais ele assemelha-se a uma. É depois de fazer reuniões, preencher formulários, entrar em filas, imprimir duas vias que o apelo daquela lei que apresenta um novo obstáculo nos faz exclamar: só podem estar de brincadeira comigo.

Mesmo nos eventos mais noticiados da política nacional dos últimos tempos, a associação entre política e brincadeira está presente. Desde o início do seu mandato como presidente da Câmara, Eduardo Cunha ficou famoso por suas manobras regimentais, repetindo votações, adiando seu próprio processo de cassação e usando o processo de impeachment como moeda de troca. Depois de muitos adiamentos e protelações para decidir o futuro do mandato do Cunha na 
Comissão de Ética, o jornalista Artur Xexéo disse no - tampouco sério - programa Liberdade de Expressão da CBN:

"Virou uma brincadeira, né? Virou um... Ontem um deputado se ofendeu por ter sido chamado de 'a turma do Cunha', mas virou uma brincadeira da turma do Cunha. É uma turma do Cunha mesmo, que chega lá pra... vou tentar não falar essa palavra. Chega lá pra tentar adiar, bagunçar, pra não acontecer. Às vezes você tem a impressão de assistir a Escolinha do Professor Raimundo e não uma sessão de parlamentares no Conselho de Ética ${ }^{36}$." (Programa veiculado no dia 11/12/2015)

Ainda sobre Cunha, quando de última hora ele decidiu que a votação para a composição da comissão especial que apreciaria o processo de impeachment seria secreta, o ministro Barroso do STF o comparou a um menino que leva a bola para casa quando está perdendo ${ }^{37}$. As mudanças de regra "no meio do jogo" para benefício próprio são comuns no parlamento, assim como o apelo para que as regras sejam seguidas e o jogo continue do jeito que está. A brincadeira de Cunha impulsionou a mídia e o juiz do STF a clamarem por seriedade, respeito pelas regras e pelas instituições. O jornalista e o juiz querem acabar com toda essa palhaçada. Para eles, a brincadeira deve ser exterminada da política e do parlamento. O Estado parece ser incompatível com ser criança. Para fazer política, deve-se usar gravata, seguir as regras, ser responsável, ser adulto.

Quanto mais insistem na seriedade do Estado, mais perduram as regras do jogo político. A medida que os burocratas do INCRA - ou os parlamentares e juízes do STF - enfatizam que estão sendo orientados pelo que a lei manda, mais a brincadeira se estende. Os jogadores lidam com frivolidade em relação às regras ao mesmo tempo em que clamam por seriedade no jogo. As privações continuam, as instituições permanecem e o jogo segue quanto mais tentam acabar com a brincadeira. A condição para que uma criança continue levando a sério demais uma brincadeira é que ela continue, ainda que não tenha mais graça jogar com quem não sabe brincar.

“O hábito entra na vida como brincadeira, e nele, mesmo em suas formas mais enrijecidas, sobrevive até o final um restinho de brincadeira. Formas petrificadas e irreconhecíveis de nossa primeira felicidade, de nosso primeiro terror, eis o que são os hábitos. E mesmo o pedante mais insípido brinca, sem o saber, de maneira pueril, não infantil, brinca ao máximo quando é pedante ao máximo. Acontece apenas que ele não se lembrará de suas brincadeiras, somente para ele uma obra

$36<\mathrm{http} / / /$ cbn.globoradio.globo.com/comentaristas/liberdade-de-expressao/2015/12/11/CUNHA-E-DILMA-SAODOIS-CHANTAGISTAS.htm>

$37<$ http://cbn.globoradio.globo.com/editorias/politica/2015/12/17/SE-NAO-ESTOU-GANHANDO-LEVO-A-BOLAPARA-CASA-DIZ-BARROSO-SOBRE-CUNHA.htm> 
como essa permaneceria muda." (BENJAMIN, 2009: 102)

As reuniões viram rotina. Os formulários viram hábito. Os processos do Estado transformam-se em cotidiano. E como nos lembra Benjamin (2009) sobre todo hábito, a ludicidade primordial é sempre reminiscente. Por mais que os jogadores esqueçam, as regras têm origem na frivolidade. A seriedade é um desdobramento de uma brincadeira. De tanto repetir o jogo, esquecem-se que tudo sempre se tratou de uma brincadeira. O verbo esquecer aqui não é utilizado em uma perspectiva temporal e evolucionista. Não se trata de uma consciência perdida em algum tempo histórico - apesar desta tampouco ser uma hipótese descartável. O sentido que busco com o verbo esquecer é de suspensão de uma mensagem metacomunicativa. Uma brincadeira que precisa ser levada a sério para que se continue brincando. Uma brincadeira em que precise-se repetir o tempo todo que não está para brincadeira.

O movimento também brinca. Todavia, as brincadeiras do Estado e do movimento possuem características distintas. A brincadeira do INCRA individualiza a conquista da terra, atomiza as pessoas nas propriedades, mina a luta coletiva. No MST, ela produz relações familiares e transindividuais, trocas de afetos e lutas entre militantes e ocupa a terra. Na escola, as crianças brincam e desenham para tornarem-se adultos capazes e independentes. Na queimada do acampamento, as crianças convivem com diferentes idades. A brincadeira do Estado produz indivíduos, jogadores e estratégias. A brincadeira do movimento produz luta, família e terra.

No encontro entre as brincadeiras do Estado e do movimento vai desenrolando a vida e a morte das famílias. A resposta do movimento para quem tem o hábito de brincar com a morte, com o perigo, com a vida das pessoas foi desobediente. Mudaram-se para as parcelas. Não esperaram a portaria de assentamento sair. Somente tratando com irreverência as leis de quem estava brincando é que as militantes puderam ter acesso à terra. Foi por não levar tão a sério as leis que o movimento pode iniciar uma ocupação de uma terra que produzia eucalipto. E aos poucos a reforma agrária vai sendo construída no Canaã: assumindo que, no fundo, trata-se de uma brincadeira e, por isso, não deve ser levada tão a sério. 


\section{CONSIDERAÇÕES FINAIS}

Entre os eucaliptos no Canaã crescem plantas, crianças, movimentos e ideias. Dentre as ideias, a quebra da oposição rígida entre ser criança e ser adulta foi provavelmente a que mais afetou a escrita dessa dissertação. Em vez de conceber crianças e adultas somente em termos anatômicos ou etários, essa distinção poderia ser considerada de maneira físiológica, ou seja, tal ideia de ser criança seria um fluxo que coloca em movimento a todos, não somente as crianças. Decorre disso, uma convivência entre crianças e adultas no trabalho, em casa, nas atividades políticas e na vida. Ao longo deste trabalho, argumentei que essa forma de pensar e de ser criança e ser adulta tem impactos múltiplos nas relações, na noção de pessoa, na política, na educação e nas brincadeiras. Em um lugar em que crianças e adultas não possuem ontologias distintas, tempo, política e faz de conta mesclam-se em uma forma de ocupar o chão para desafiar o Estado.

Essa perspectiva impacta a concepção de quem faz a luta. A luta não era entendida enquanto propriedade dos indivíduos. Por diversas vezes, ouvi que a luta é da família, ultrapassando as separações estanques de pessoas singulares. A família era um recipiente trans-individual que continha a luta coletiva e não, mais uma vez, um todo atávico, marcado meramente por anatomias e idades distintas de seus membros. O pedaço de terra só se torna possível por uma luta coletiva que envolve muitas famílias, formadas, na maioria das vezes, por mulheres e crianças - e em algumas vezes por homens também. Quando os militantes diziam que a luta é da família, também diziam que mulheres e crianças lutam. Os adultos ocupam a terra junto com as crianças. Transformam juntos uma monocultura de eucalipto em moradia. Como Eliana nos lembra, luta é criar os filhos no meio da terra, é buscar água do caminhão-pipa, é construir um campinho e brincar de queimada em uma ocupação. A luta é de toda a família e a ela pertence, assim como tal noção de família pertence à luta. A luta é feita com a vida no Canaã. As famílias dão vida à ocupação habitando nela, plantando, colhendo e resistindo. Vida e política no Canaã são imbricadas, como na ocupação Mauá (SP) pesquisada por Paterniani (2013), e as crianças fazem parte desse imbricamento. Crianças ocupam a terra com as suas vidas e participam da política.

Nessa combinação entre vida e política, as brincadeiras adentraram e ocuparam o Canaã, os órgãos públicos e a Praça do Buriti. Em um movimento expansivo, o pique cola movimentava as crianças na direção contrária do pego e da igreja mal assombrada, ignorando limites e contornos estanques da brincadeira. Na queimada, cravavam na terra vermelha os limites de cada campo com o pé ou colocando um chinelo. Como um pêndulo, corriam de um lado para o outro quando a bola 
estava com o time adversário. Em um movimento onírico, Caetano rompeu as distinções entre realidade e ficção no seu faz de conta em frente ao Palácio do Buriti. Com todos esses movimentos, a terra foi ocupada. Com toda a sua intensidade, as crianças participam da política. As brincadeiras produziram luta, movimento, relações e transformações nos espaços misturando vida e política e quebrando a alteridade entre crianças e adultas.

A noção de que a luta é da família comporta todos esses movimentos e relações. Englobando gerações de adultos e crianças, a família luta e ocupa a terra com toda sua potência. Isso envolve uma conexão diferenciada com o tempo. Uma conexão com o passado de mães, pais, dos avós e parentes de outras gerações, muitos já mortos. Tal conexão perpassa as gerações que virão no futuro. No projeto de luta da família, a terra onde as crianças brincam no presente, quando conquistada, se transformará na que as crianças do futuro poderão brincar. O lugar onde as mães criam os filhos mudará junto com as gerações do futuro. Nessa terra em que os idosos da família precisam de cuidado, precisam usar fraldas, quem virá vai envelhecer. Essa terra metamorfoseada é - foi e será - compartilhada por crianças, adultas e idosas das gerações passadas e futuras. Como disse Eliana ( p. 24), a monocultura de eucaliptos não pertence a essa terra de compartilhamento de brincadeiras e vida.

O tempo também comprime passado e futuro no compartilhamento da brincadeira por diferentes gerações. Crianças e adultos, mães e filhos brincam juntos e também conectam-se com o passado e com o futuro. Não com uma lembrança individual da criança interior de cada um. A criança não é o passado do adulto aqui. Crianças e adultos são o passado. O devir criança é pulsante nas crianças e adultas do presente como foi nas crianças e nas adultas anteriormente. Ser criança atravessa as gerações, mantendo as brincadeiras vivas na terra, assim como a terra viva nas brincadeiras. O passado e a criança não são interiores, privados. Ambos são compartilhados. Adultos e crianças são inseparáveis em qualquer linha do tempo.

Não foram em todas as brincadeiras em que essa convivência entre adultos e crianças aconteceu. No dominó, as crianças pequenas foram impedidas de jogar por não saberem as regras. Os adultos do jogo de dominó em frente ao Palácio do Buriti estavam levando a sério o jogo. Queriam ganhar e, por isso, traçavam estratégias, pensavam na próxima jogada. A intromissão de uma criança pequena em um jogo de dominó em que os jogadores não abdicam de ganhar ou perder atrapalha. A criança, avessa a traçar as estratégias e a seguir as regras do jogo, bagunça. Quando o jogo é como o de dominó, a convivência entre crianças e adultas não funciona do mesmo modo: elas não podem brincar/jogar juntos. Para o caso de jogos desse tipo, espera-se pelo tempo em que a criança já não mais o será. Espera-se que no futuro, quando a criança crescer e aprender as regras, ela poderá jogar. $\mathrm{O}$ sério, aqui, seria um desdobramento da brincadeira, que ao suspender a 
mensagem "isso é uma brincadeira": interrompe o fluxo entre crianças e adultos, provocando de certa maneira a paralisia de ambos.

É também quando levam a sério a brincadeira que Lucas e Leonardo jogam a bola forte demais, tornando a queimada hostil para as crianças pequenas. Levar a sério demais a brincadeira abre brecha para uma cisão entre capazes/incapazes, ganhadores/perdedores, adultos/crianças, passado/futuro. A brincadeira levada a sério precisa de regras mais rígidas, de preferência, acordadas antes do jogo para que ninguém delas escape. Ser criança ou pequeno é uma desvantagem na brincadeira levada a sério. $\mathrm{O}$ adulto leva vantagem em ser sério. A seriedade quebra a simultaneidade do tempo. A ordem com que as coisas aconteceram passa a ser importante: quem foi primeiro, quem foi depois, quem começou. Concepções sobre ser adulto e ser criança, assim como diferentes graus de seriedade e jocosidade têm implicações na educação, na política, nas relações e na brincadeira.

$\mathrm{Na}$ escola, as distinções entre criança/adulto, sério/brincadeira são muito evidentes. Adultos estudam à noite e crianças estudam de manhã ou de tarde. Os conteúdos do Ensino Médio e Ensino Fundamental são separados com base na diferença das capacidades de crianças e adolescentes. As idades são segregadas em uma linha que leva do mais infantil ao mais adulto. No Canaã, os ônibus dos menores e dos maiores são diferentes. Respeitando o tempo "certo", a escolarização deve começar quando somos crianças pequenas e só deve terminar quando estamos prontos para o mundo adulto. Nela o tempo é organizado para fazer essa separação. Tem hora para brincar e hora para falar sério. Hora do recreio e hora do conteúdo. Com essa separação, a brincadeira passa a ser compatível com a escola. É possível até aprender brincando. Para boa parte das psicólogas e pedagogas, brincar é uma maneira saudável de socialização e aprendizado e leva a adultas mais seguras e inteligentes. Brincar também é uma maneira das crianças interpretarem e reproduzirem a cultura adulta de maneira criativa entre pares da geração (CORSARO, 2002). Distinguindo as ontologias, as brincadeiras na escola são um instrumento pedagógico importante para reproduzir adultos que não serão mais crianças.

A escola é inclusive o lócus em que são ensinadas as noções de tempo e de espaço universalistas. $\mathrm{Na}$ escola, as crianças aprendem a contar os anos, os metros, o tamanho da área, a idade e o volume. De acordo com as capacidades de cada idade, as crianças aprendem que o tempo dos avós e bisavós passou e é diferente do tempo presente. Na escola é ensinado que a área de uma porção de terras é medida em hectares. A ideia de uma terra compartilhada simultaneamente por diferentes gerações de avós, bisavós, netos e bisnetos de tempos distintos fora de uma lógica linear não cabe na escola.

Nesse mundo sério de pessoas escolarizadas, Rosa não tem vergonha de dizer que é criança 
também. Enche a mão de pipoca e entra em guerra. Assiste desenho animado. Alberto fica à vontade ao lançar a bola e correr de um lado para o outro na queimada. Eliana canta as músicas do movimento com alegria. Os moradores do Canaã convivem com as crianças e dão vazão ao ser criança nas suas relações, nas suas brincadeiras. A socialização da criança em direção ao adulto é substituída por caminhos múltiplos de ida e volta entre os dois devires. Em vez de uma educação separada de acordo com a fase da vida, o aprendizado é construído na convivência entre os diferentes.

Assim como na escola, na política do Estado, a distinção entre crianças e adultos também é operante. As crianças são consideradas politicamente incompetentes e a elas são negadas a participação política e o direito ao voto (QVORTRUP, 2010). O Estado trata de assuntos sérios e deve ser gerido com esta perspectiva. A maioria dos teóricos do Estado e da política da academia não encontrou lugar para as crianças em suas teorias:

“Assim, Marshall (1950), cientista político britânico que escreveu um livro muito sugestivo sobre cidadania depois da Segunda Guerra Mundial, não encontrou um lugar para as crianças; o filósofo do direito americano John Rawls (1971) mostrou a mesma dificuldade; e o sociólogo alemãobritânico Ralf Dahrendorf (1996) fala explicitamente das crianças como "um problema embaraçoso" - em outras palavras, um problema irritante e enfadonho que atrapalha discussões sérias entre pessoas adultas sobre pessoas maduras." (QVORTRUP, 2010: 780 e 781)

O Estado é calcado na separação entre crianças e adultas. Para lidar com o Estado, as crianças precisam ser mediadas por adultas. O Estado é adultocêntrico. No entanto, isso não significa que o ser criança não consegue atravessar o Estado. Por mais que não seja admitido, o Estado brinca com a vida das pessoas. Por meio de formulários, relatórios e burocracias sérias, Estado burla as próprias regras, atravanca processos, faz jogadas arriscadas, desenvolve estratégias. É uma brincadeira que consiste em esconder - e mesmo aniquilar - seu caráter infantil. Não admitese brincadeira e posturas infantis dentro do Estado.

A comunicação com o Estado é a negação da mensagem metacomunicativa "Isso é uma brincadeira" de que fala Bateson (1972). Quem lida com a burocracia e com as leis constantemente passa a mensagem de que não está para brincadeira. Se os signos na brincadeira não denotam o que denotariam fora dela, nas negociações com o Estado, a lei, os documentos, as conversas não admitem nenhuma ambiguidade. Lidar com o Estado é um jogo sério. Para lidar com o Estado, não basta ser um adulto. É preciso manter a seriedade e compostura de um.

Denunciar sua falta de seriedade faz parte do jogo. O atual presidente da Câmara de 
Deputados Eduardo Cunha é constantemente denunciado por brincar no exercício da sua função. Enquanto escrevo essa dissertação, manifestantes vão às ruas pedir o impeachment do governo Dilma. Muitos deles usam narizes de palhaço para expressar sua indignação e denúncia ao governo. A Federação das Indústrias de São Paulo (FIESP) espalhou mais de vinte patos infláveis de 12 metros de altura nas manifestações ${ }^{38}$ : patos que na sua escala original seriam parceiros de crianças durante seu banho, tornam-se na sua versão agigantada, soldados dos beneficiários da corrupção (donos do capital) na sua luta contra a corrupção. E tudo isso não é brincadeira, mas coisa séria. Em suma, política. É como na brincadeira de ficar sério entre Leonardo e Lucas no acampamento. Nesta brincadeira, perde quem não manter a postura de seriedade e rir primeiro. $\mathrm{O}$ resultado desta brincadeira do Estado é a fabricação de indivíduos atomizados. Para o Estado, ser adulto é ser uno, ser indivíduo, pleno em suas capacidades. Deve-se dominar todos seus impulsos infantis e manter a seriedade. A pessoa que não cumpre com suas obrigações e papéis de maneira responsável não é um adulto pleno. Quanto mais os jornalistas, juízes, manifestantes e deputados denunciam atualmente a falta de seriedade dos outros jogadores, mais fazem-se adultos responsáveis, indivíduos plenos.

Para lidar com o INCRA, as acampadas do Canaã também tiveram que se fazer de sérias e denunciar a falta de seriedade do INCRA. Nas negociações por terra, reforma agrária, por chão, as acampadas diziam que o INCRA estava de brincadeira e que elas não estavam com tempo para isso. As reuniões no INCRA repetiram-se à exaustão. A cada hora, o INCRA apresentava um obstáculo para as famílias. A ambiguidade de expandir e em outros comprimir os prazos e expectativas para cair para as parcelas soava como uma brincadeira. Porém, reside uma diferença substancial no fazer-se sério dos acampados do Canaã e dos outros jogadores. A luta das famílias do Canaã busca a terra para além do indivíduo. Ocupam a terra em uma perspectiva trans-individual, que perpassa diferentes famílias e gerações. Fazem-se de adultos nos prédios do INCRA para serem simultaneamente adultos e crianças em suas terras.

O movimento das famílias na praça também brinca. Não leva a sério as ordens policiais e ocupam a via. São irreverentes com o tempo dos processos do INCRA e caem para as parcelas. As famílias desobedecem as regras da propriedade e ocupam uma terra improdutiva. A criança fisiológica que atravessa cada um não é incompatível com essa forma de fazer política. Admitem a possibilidade de serem desobedientes e sérios ao mesmo tempo. Brincar e fazer política responsável não se opõem neste movimento. Fazem movimento com a seriedade que uma criança encara uma brincadeira.

Boa parte das ciências sociais - e da antropologia em particular - também sustenta a

$38<\mathrm{http}$ //epoca.globo.com/tempo/expresso/noticia/2016/03/em-dia-de-protesto-fiesp-espalha-mais-de-30-patosinflaveis-contra-alta-de-impostos.html> 
separação entre crianças e adultos no desenvolvimento de suas pesquisas. As crianças são simplesmente ignoradas em parte considerável das etnografias, artigos e projetos de pesquisa, sugerindo que somente adultos habitam as formações sociais estudadas. As vozes das crianças é quase restrita aos campos da antropologia da criança e sociologia da infância. E mesmo nestes campos, há quem defenda a generalização da existência de "culturas infantis" (SARMENTO, 2005; CORSARO, 2002) relativamente autônomas do mundo dos adultos.

Calcada na ideia de alteridade, a organização da antropologia ocorreu a partir da concepção de que crianças constituiriam um objeto à parte. Esta separação entre objetos de pesquisa - crianças e adultas - contribuiu muito pouco para refletir sobre a diversidade de maneiras de ser adulta nas etnografias. As ênfases nas vozes dos adultos nas pesquisas não renderam maiores reflexões sobre esta categoria. Nesta divisão, coube às pesquisas com crianças fazer este tipo de reflexão, uma vez que pesquisar crianças prescinde de uma negociação com as expectativas que envolvem ser adulta (PIRES, 2007). Essas investigações abrem caminho para o rompimento epistemológico com a divisão ontológica entre crianças e adultas, questionando a própria maneira como estas divisões científicas - e antropológicas - são constituídas. Se, como Rosa, adultas podem ser crianças também, temos em mãos reflexões que podem afetar pesquisas em múltiplos lugares e contextos que vão muito além das pesquisas com crianças. No limite, a divisão entre as reflexões da antropologia da criança e das demais áreas perderia seu sentido epistêmico.

Em meio às divisões de campos e subcampos, "levar a sério" segue sendo uma expressão usada por toda a antropologia. Uma boa antropóloga deve levar a sério os "nativos", seus discursos, conceitos e práticas. A questão é que esta seriedade esconde uma brincadeira. Dar consequência a este esforço de levar a sério as pessoas com quem fazemos requer o compromisso de continuamente brincar com os pressupostos antropológicos. Se levamos a sério o "nativo" que brinca com as próprias convenções, como podemos não fazer o mesmo com as nossas? Ou apostamos que levar a sério "as nativas" produz deslocamentos nos conceitos antropológicos, ou corremos o risco de, na tentativa de levá-las a sério, fazer delas pessoas sérias, como nós. Sobre esta relação entre levar-se a sério e jogar com a convenção, Wagner (2009) diz:

“[É] preciso “jogar” e sacrificar a própria seriedade para que a convenção (Cultura) possa ser levada a sério. (...) Uma personalidade que se leva demasiadamente a sério, por outro lado, joga com a convenção; ela falsifica a Cultura e a convenção cultural.” (WAGNER, 2009: 204)

Levar a sério as crianças pode significar não levar nem um pouco a sério as convenções. As etnografias podem pedir que não levemos a sério a Antropologia. Uma brincadeira pode demandar 
atrevimento com as regras do Estado. Tratar as pessoas com seriedade é admitir que a Política, a Escola e a Antropologia não passam de brincadeiras, ou seja, que podemos inventá-las sem ter que seguir as regras e convenções à risca ou, em outras palavras, que podemos transformá-las e não sucumbirmos a elas.

Brincando com os conceitos, nossas pesquisas podem ser mais parecidas com o faz de conta de Caetano. Uma invenção que não é concebida partindo das oposições entre verdade e mentira, realidade e ficção. Elaborações conceituais em que caibam a criatividade dos sonhos. As pesquisas podem abdicar das explicações causais para muito expressar. Isso não quer dizer ter menos potência política. Caetano denuncia a brutalidade de viver entre os eucaliptos no simples gesto de levantar seus braços e tombar para o lado. O menino ocupava a Praça do Buriti enquanto virava um gigante pegando fogo. O faz de conta de Caetano tem uma epistemologia própria e que deve ser levada a sério para brincar com os conceitos da antropologia.

A experiência etnográfica com as acampadas do Canaã me trouxe a oportunidade de refletir sobre tempo, política e faz de conta. A perspectiva de que a terra conecta gerações de diferentes tempos tem implicações políticas profundas no movimento das acampadas. A política é construída cotidianamente com brincadeiras inventadas, gigantes, eucaliptos e relógios de faz de conta na ocupação da terra. A brincadeira perpassa gerações de crianças e adultas e dá vida à ocupação da terra em Brazlândia. Brincando na terra, entre os eucaliptos, crianças e adultos constroem a ocupação Canaã. 


\section{Referências Bibliográficas}

ARIES, Philippe. História Social da Criança e da Família. Editora Guanabara S.A. Rio de Janeiro. 1981.

BASCOM, William. The Yoruba of Southwest Nigeria. New York: Holt, Rinehart and Winston. 1969

BATESON, Gregory. Steps to an Ecology of Mind. Chicago: The University of Chicago Press. 2000 [1972]

BELISÁRIO, Gustavo. A Rua é Pública! A Boca é nossa! Uma etnografia com crianças em uma escola na Cidade Estrutural-DF. Monografia de graduação. 2013.

BENJAMIN, Walter. Reflexões sobre o brinquedo, a criança e a educação, SP, Ed. 34. Segunda Edição 2009.

BERGSON, Henri. Duração e simultaneidade. [1922] Trad. de Cláudia Berliner. São Paulo: Martins Fontes, 2006.

BISPO, Antônio. Colonização, quilombos, modos e significados. Instituto Nacional de Ciência e Tecnologia de Inclusão no Ensino Superior e na Pesquisa (INCTI/UnB). Brasília. 2015

BORGES, COSTA, BELISÁRIO, CIRNE, LIMA, VIANA \& PATERNIANI. Pós-Antropologia: as críticas de Archie Mafeje ao conceito de alteridade e sua proposta de uma ontologia combativa. Sociedade e Estado. Vol. 30. n. 4.2015.

BORGES, Antonádia; KAEZER, Verônica. O Recanto dos Meninos. MILSTEIN, Diana et al. Encuentros etnográficos con niñ@s y adolescentes. Entre tiempos y espacios compartidos. Buenos Aires: Miño y Dávila, 2011.

BORGES, Antonádia. Tempo de Brasília: Etnografando lugares eventos da política. Rio de Janeiro: Relume Dumará, 2004.

. Explorando a noção de etnografia popular: comparações e transformações a partir dos casos das cidades-satélites brasileiras e das townships sul-africanas. Cuadernos de Antropología Social, v. 29, 2009.

Bruxaria e Estado como (pre)conceito: contrastes etnográficos e limites da linguagem e antropologia. In: Antropologia. Razão e Poder na pesquisa etnográfica contemporânea. Org. BORGES, Antonádia. Thesarus. Brasília 2014.

BUSS- SIMÃO, Márcia. Antropologia da Criança: uma revisão da literatura de um campo em construção. Revista Teias, v.10, n.20, julho de 2009.

CARDOSO, R. S. B.; PIRES, L. V. Algumas considerações sobre a monocultura do eucalipto e 
suas implicações. In: SIMPÓSIO INTERNACIONAL DE REFORMA AGRÁRIA 4.; SIMPÓSIO NACIONAL DE GEOGRAFIA AGRÁRIA, 5., Universidade Federal Fluminense, 2009. Disponível em: <http://www.uff.br/vsinga/trabalhos/Trabalhos\%20Completos/Rafael\%20Said\%20Bhering $\%$ 20Cardoso.pdf $>$

CASTRO, Camila Penna de. Conexões e controvérsias no Incra de Marabá: o Estado como um ator heterogêneo. 383 f., il. Tese (Doutorado em Sociologia)—Universidade de Brasília, Brasília, 2013.

COHN, Clarice. Antropologia da Criança. Rio de Janeiro: Jorge Zahar Editor, 2005.

. Concepções de infância e infâncias. Um estado da arte da antropologia da criança no Brasil. Civitas. Porto Alegre, v. 13. n. 2. 2013.

COMAROFF, Jean; COMAROFF, John. Naturalizando a Nação: estrangeiros, apocalipse e o Estado pós-colonial. Horizontes Antropológicos, Porto Alegre, n. 15, ano 7, p.57-106, 2001.

COMERFORD, John. Como uma familia. Sociabilidade, territórios de parentesco e sindicalismo rural.Rio de Janeiro: Relume Dumará: Núcleo de Antropologia Política/ UFRJ, 2003

. Vigiar e narrar: sobre formas de observação, narração e julgamento de movimentações. Revista de Antropologia. v. 57, no 2. São Paulo. 2014.

CORSARO, William. A. A reprodução interpretativa no brincar ao "faz-de-conta" das crianças.Educação, Sociedade e Cultura: Revista da Associação de Sociologia e Antropologia da Educação, Porto, v. 17, p. 113-134, 2002.

CORTES, Verônica. A relação entre configurações de poder e jogos políticos em organizações públicas. Tese de Doutorado. Instituto de Psicologia. Universidade de Brasília. 1999.

DELEUZE, Gilles. \& GUATTARI, Félix. Mil platôs: Capitalismo e Esquizofrenia (Vol. 4 e 5). Rio de Janeiro: Ed. 34 Letras. 1997 (Original publicado em 1980)

DELEUZE, Gilles. . O que as crianças dizem? Em G. Deleuze (Org.), Crítica e clínica (pp. 73-79). Rio de Janeiro: Ed. 34 Letras. (1997)

Bergsonismo. Tr. Luiz Orlandi. São Paulo: Ed. 34, 1999

Spinoza. Curso de Gilles Deleuze dado no dia 17 de fevereiro de 1981. Traduzido por Ernesto Hernández B. (1991). <http://www.webdeleuze.com/php/texte.php?

cle $=39 \&$ groupe $=$ Spinoza $\&$ langue $=3>$

FEREJOHN \& PASQUINO, A teoria da escolha racional: conceitos de racionalidade política. RBCS, vol 16, no 45. 2001.

FIANS, Guilherme; Entre Crianças, Personagens e Monstros: Uma Etnografia de Brincadeiras Infantis. 1. ed. Rio de Janeiro: Ponteio Edições, 2015. 184p .

FREUD, Sigmund. (1900). A interpretação dos sonhos. In: Edição standard brasileira das obras psicológicas completas de Sigmund Freud. 2.ed. Rio de Janeiro, Imago, 1987. v. 4, 5. 
(1905) Três ensaios sobre a teoria da sexualidade. Editora Imago. Rio de Janeiro.

1973.

HARTMANN, Luciana. Crianças contadoras de histórias: narrativa e performance em aulas de teatro. Revista do Programa em Pós-Graduação em Arte da UnB. V. 13 no. 2. Brasília. 2015.

HERZFELD, Michael. The Social Production of Indifference. Chicago: The University of Chicago Press, 1993.

HUIZINGAM, Johan. Homo Ludens. O jogo como elemento da cultura. São Paulo: Editora Perspectiva, 2000.

LIMA, Mariana. Sem-Terrinha em ação pra fazer revolução: Um diálogo entre a ocupação dos SemTerrinha ao MEC e a Antropologia da Criança. Apresentação no III Conversas da Kata. Brasília. 2015.

KASTRUP, Virgínia . O devir-criança e a cognição contemporânea. Psicologia: reflexão e crítica, 13(3), 373-382. 2000

KISHIMOTO, Tizuko. O brincar e suas teorias. São Paulo: Pioneira, 1998

MAFEJE, Archie. The ideology of "Tribalism".The Journal of Modern, African Studies. v. 9, n. 2, p. 253-261, 1971.

. The theory and ethnography of african social formations. The case of the interlacustrine kingdoms. London: Codesria book Series. 1991.

PATERNIANI, Stella. Política, fabulação e a ocupação Mauá: etnografia de uma experiência. Dissertação de Mestrado. Unicamp. 2013

PIAGET, Jean. e INHELDER, B. Da Lógica da Criança a Lógica do Adolescente. São Paulo: Ed. Pioneira, 1976. 260p. (Capítulo 17)

PIAGET, Jean (1976) Seis Estudos de Psicologia. Rio de Janeio:Forense. 2006.

O Estruturalismo. São Paulo: Difel, 1979.

PIRES, Flávia, "Crescendo em catingueira: criança, família e organização social no semiárido nordestino".Mana, 18: 539-561. 2012

Ser adulta e pesquisar crianças: explorando possibilidades metodológicas na pesquisa antropológica. Revista de Antropologia. Vol 50, no. 1. 2007.

QVORTRUP, Jens. Infância e política. in Cadernos de Pesquisa, Revista Quadrimestral SeptemberDecember vol. 40, no. 141, pp. 777-792. (2010)

ROSA, Marcelo. Engenho dos Movimentos Sociais: Reforma Agrária e significação social na zona canavieira de Pernambuco. Editora Garamond. 2011. 
SARMENTO, Manuel. Gerações e alteridade: interrogações a partir da sociologia da infância. Educação e Sociedade, vol. 26, n. 91, 2005.

SARMENTO, Manuel Jacinto e PINTO, Manuel. As crianças e a infância: definindo conceitos, delimitando o campo. In: SARMENTO, Manuel Jacinto e PINTO, Manuel. As crianças, contextos e identidades. Braga, Portugal. Universidade do Minho. Centro de Estudos da Criança. Ed. Bezerra, 1997.

SCHWARTZMAN, Helen. Transformations: The Anthropology of Children's Play. New York and London: Plenum Press, 1978.

SHEPSLE, Kenneth \& BONCHEK, Mark. Analyzing Politics. Rationality, behavior and institutions. W. W. Norton \& Company. 1997.

SIGAUD, Lygia; FAJOLLES, David; GAUTIÉ, Jérôme; GÓMEZ, Hernán \& SMIRCIC, Sergio.. (2006), "Os Acampamentos da Reforma Agrária: História de uma Surpresa”, in B. L'Estoile e L. Sigaud (orgs.), Ocupações de Terra e Mudança Social: Uma Experiência de Etnografia Coletiva. Rio de Janeiro, Editora FGV, pp. 29-63.

SOUZA, Clóvis. Partilha de poder decisório em processos participativos nacionais. Dissertação de Mestrado. Universidade de Brasília 2008.

SOUZA, Ádamo. A teoria dos jogos e as ciências sociais. Dissertação de Mestrado. UNESP Marília. 2003.

STRATHERN, Marilyn. O gênero da dádiva. Problemas com as mulheres e problemas com a sociedade na Melanésia. Campinas, Editora da Unicamp, 2006.

TAMBIAH, Stanley. Múltiplos ordenamentos de realidade: o debate iniciado por Lévy-Bruhl. São Paulo. Cadernos de Campo v. 22. 2013.

TASSINARI, Antonella. Múltiplas Infâncias: o que a criança indígena pode ensinar para quem já foi a escola - ou a sociedade contra a escola. 33 Encontro Anual da Anpocs. Caxambu, 2009. $<\mathrm{http}: / /$ portal.anpocs.org/portal/index.php?

option $=$ com_docman\&task $=$ doc_view\&gid=1935\&Itemid $=229>$

VYGOTSKY, Lev. A formação Social da Mente. São Paulo: Martins Fontes. $4^{\text {a }}$ edição. 1991.

WAGNER, Roy. A Invenção da Cultura. São Paulo: Cosac Naify, 2009. 